\title{
WPS3491
}

\section{Use of the Formal and Informal Financial Sectors: Does Gender Matter? Empirical Evidence from Rural Bangladesh}

\author{
Signe-Mary McKernan* \\ The Urban Institute \\ Mark M. Pitt \\ Brown University \\ David Moskowitz \\ The Urban Institute
}

World Bank Policy Research Working Paper 3491, January 2005

The Policy Research Working Paper Series disseminates the findings of work in progress to encourage the exchange of ideas about development issues. An objective of the series is to get the findings out quickly, even if the presentations are less than fully polished. The papers carry the names of the authors and should be cited accordingly. The findings, interpretations, and conclusions expressed in this paper are entirely those of the authors. They do not necessarily represent the view of the World Bank, its Executive Directors, or the countries they represent. Policy Research Working Papers are available online at http:/lecon.worldbank.org.

*Corresponding author: e-mail: smckerna@ui.urban.org; Address: The Urban Institute, 2100 M Street, NW, Washington, DC 20037. We thank Nayantara Mukerji, Susan Razzaz, M. Estela Rivero-Fuentes, and five anonymous reviewers for helpful comments on earlier drafts and Natsuko Kiso for excellent research assistance. This research has been financially supported by the Bank-Netherlands Partnership Program's Economic Policy and Gender Initiative. 


\section{Table of Contents}

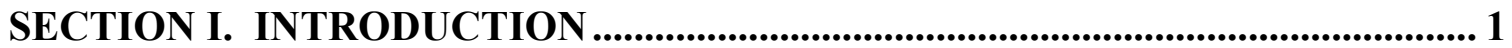

SECTION II. RELEVANT LITERATURE ............................................................. 3

A. THE IMPORTANCE OF INFORMAL GIFTS AND LOANS ............................................... 3

B. THE RELATIONSHIP BETWEen the Formal AND INFORMAL SECTORS ........................ 5

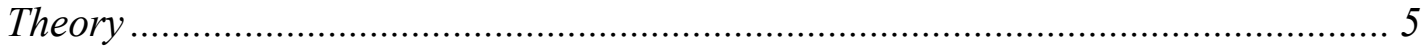

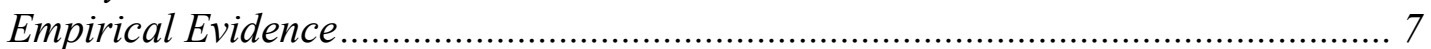

C. REASONS FOR TARGETING WOMEN WITH TRANSFERS AND CREDIT.......................... 9

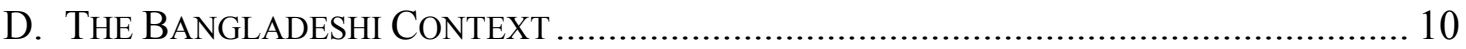

E. OuR Contributions to the Literature ....................................................... 11

SECTION III. DATA AND DEFINITIONS ……........................................................ 12

A. DATA ㄴ..ㄴ...

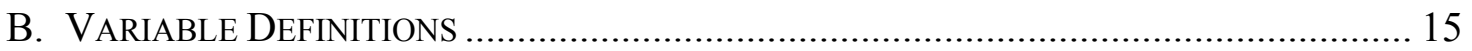

SECTION IV. DESCRIPTIVE RESULTS................................................................. 17

A. The Relative Importance of the Formal and Informal Financial Sectors

B. HOUSEHOLD AND INDIVIDUAL CHARACTERISTICS OF RECIPIENTS ...........................2 20

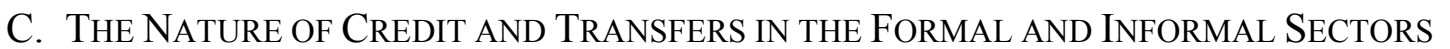

D. THE ROLE OF FORMAL AND INFORMAL SECTORS BY GENDER ………..................... 27

E. THE RELATIONSHIP BETWEEN THE FormaL AND INFORMAL SECTORS ....................... 32

F. Changes IN the Financial SeCtors BetweEn 1991/92 AND 1998/99 _................... 35

SECTION V. REGRESSION RESULTS .............................................................. 43

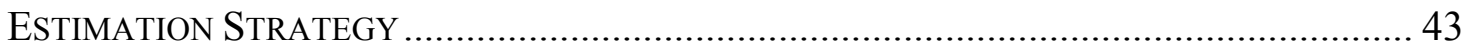

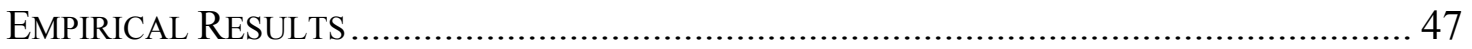

SECTION VI. CONCLUSIONS AND POLICY IMPLICATIONS .......................... 53

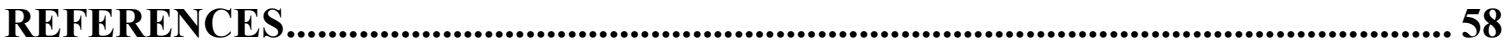

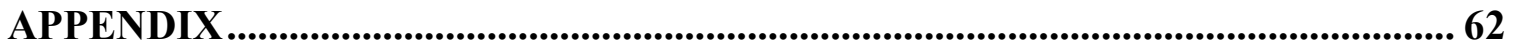

REGRESSION RESULTS: FULL SETS OF COEFFICIENTS …………………….................. 62 


\section{Section I. Introduction}

Access to transfers and credit, whether cash or in-kind, is a major source of poverty alleviation in many developing countries around the world. For many poor households, these public and private gifts and loans make up a substantial portion of their yearly incomes and provide an important means to generate additional income. ${ }^{1}$ Women may especially benefit from transfers and credit in countries such as Bangladesh where they often have few work alternatives.

As such, the formal financial sector is currently one of the principle areas of intervention intended to provide social protection and poverty alleviation for the poor. The intervention has taken the form of formal transfers and improved access to credit and/or subsidization of credit. In addition, the development community is increasingly interested in ways to create an enabling environment for the private sector, including banks, to provide the poor with improved access to financial services.

The informal financial sector is also a key source of social protection, especially in areas with limited access to the formal financial sector. In fact, in many countries, the informal sector is much larger than the formal sector. The informal sector, which includes transactions such as gifts and loans from relatives, friends, and neighbors, may overcome barriers to the formal sector. If this is so, formal programs designed to increase access to formal financial services may actually prompt reductions in the informal sector.

In this report, we descriptively examine the formal and informal financial sectors of rural Bangladesh, placing a special emphasis on differences between men and women. Our analysis uses unique panel data on the credit and transfer behaviors of 1,800 households in rural Bangladesh. Throughout the analysis, we focus on five important questions: (1) How important are the formal and informal financial sectors? (2) What are the primary sources of gifts and loans within those sectors? (3) Do men and women rely on different sources for finances (e.g. formal vs. informal) or different types of finances (e.g. gifts vs. loans)? (4) How have the financial sectors evolved during the 1990's? (5) What is the relationship between the formal and informal sectors? The report is primarily descriptive. However, we use causal regression analysis to further investigate the relationship between the formal and informal sectors and begin to answer the question: does the formal sector crowd out the informal sector and is this different for men and women?

\footnotetext{
${ }^{1}$ For instance, in their analysis of the Philippines, Cox and Jimenez (1995) find that transfers accounted for nearly one-fifth of total household income for urban recipients in their sample.
} 
Throughout the report, we pay particular attention to the gender of the recipients of both formal and informal finances. Formal credit and transfers may alter the allocation of resources within the household. Formal sector programs, such as microfinance, often target women with the intent, explicit or implicit, of altering allocations within the household. It is not clear without recourse to the data that providing additional financial resources to women will have different effects on intra-household (and inter-household allocations) than providing those same resources to men. Conceivably, male dominance in the household may permit them to capture all of the benefits of resources provided to any other household member.

Formal credit and transfers may not only alter the allocation of resources within the household, they may also alter the allocation of resources between altruistically linked households. Household that are recipients of formal transfers and credit may transfer some of the benefits by increasing (decreasing) gifts and loans to (from) altruistically linked households, generating possible third-party effects. In the most extreme case, formal sector programs could have no income effect on their targeted population if the formal sector fully replaces the informal sector. Even in this extreme case of no income effect, programs may still have important impacts on broader measures of welfare such as women's empowerment. The sign of the relationship between the formal and informal sectors is indeterminate because assets acquired through formal sector programs may increase the credit-worthiness of households and thus lead to improved access to financial services from other sources. As part of a larger project, the final section of this report begins to explore the relationship between the formal and informal sectors.

The remainder of this report is organized as follows. Section II discusses the relevant literature on transfers and credit. Section III describes the dataset and provides important variable definitions. Section IV presents descriptive results, and Section V presents regression results. The final section summarizes important findings. 


\section{Section II. Relevant Literature}

The current credit and transfer literature sheds light on the importance of the informal sector, why the relationship between informal and formal sectors is important, reasons for targeting women with transfers and credit, and why microfinance is an important form of formal credit. This brief literature review also highlights current gaps in the literature and this report's contributions.

\section{A. The Importance of Informal Gifts and Loans}

The informal financial sector "act[s] like credit markets in helping households overcome borrowing constraints (e.g., Cox 1990), and can assist households in dealing with risk (e.g., Cox and Jimenez 1998, Morduch 1995, Townsend 1994)." The World Development Report 2000/2001 also emphasizes that households rely on both formal and informal strategies to manage risks (World Bank 2001, p. 140).

There is a significant literature documenting the importance of informal transfers and credit in developing and developed countries alike. Evidence from Ravallion and Dearden (1988) in Indonesia, Paulson (2000) in Thailand, Cox, Jimenez and Okrasa (1997) in Poland, Cox, Eser and Jimenez (1998) in Peru, Cox (2002) in Vietnam, Zeller (1994) in Madagascar, Schoeni (1997) in the United States, and others demonstrates that households rely on the informal financial sector.

The importance of informal gifts and loans varies by country, as shown in Table 1. At the extremes: in the Philippines over 80 percent of households received informal gifts, while in Bulgaria 17 percent of households received informal gifts. Poor households are more likely to receive informal transfers than wealthier households and these transactions represent a large share (up to 70 percent) of the income of the poor (Cox 2002, p. 13, World Bank 2001, p. 144). Also, fewer households send transfers than receive them (Table 1), suggesting that sending households may be supplying informal transfers to multiple recipient households.

The literature provides limited evidence on the flow of informal transfers. There is some evidence that informal transfers are more likely to flow to women, perhaps because women are more involved in the interfamily exchange of services or because women are more likely to outlive men and so receive financial help as widows (Cox and Jimenez 1992). Cox (2002) finds that informal transfers are common and substantial in Vietnam, especially as a means of support for the elderly. In general, transfers in Vietnam appear to flow from better off to worse off households (Cox, Fetzer and Jimenez 1998). While gifts flow almost exclusively between relatives, loans do not (Cox 2002, p. 16). 
TABLE 1 - Percentage of Households Participating in Informal Transfers and Credit

\begin{tabular}{|c|c|c|c|c|c|}
\hline Source & Country and Year ${ }^{1,2}$ & Receiving $^{3}$ & $\begin{array}{c}\text { Poor } \\
\text { Receiving }^{3,4} \\
\end{array}$ & Sending $^{3}$ & Receiving or Sending ${ }^{3}$ \\
\hline Zeller $(1994$, p.6) & Rural Madagascar (1992) & 96 (loans) & & & \\
\hline Cox and Jimenez (1995, Table 12-1) & Urban Philippines (1988) & 82 & & 44 & \\
\hline Cox and Jimenez (1995, Table 12-1) & Rural Philippines (1988) & 89 & & 50 & \\
\hline World Bank (2001, Table 8.5) & Jamaica (1997) & 53 & 65 & 13.1 & \\
\hline World Bank (2001, Table 8.5) & Nepal (1996) & 44.7 & 55.3 & 17.4 & \\
\hline World Bank (2001, Table 8.5) & Panama (1997) & 37.8 & 40.9 & 15.5 & \\
\hline World Bank (2001, Table 8.5) & Peru (1994) & 37.3 & 46.7 & 14.3 & \\
\hline World Bank (2001, Table 8.5) & Kyrgyz Republic (1996) & 35.5 & 31.7 & 15.7 & \\
\hline World Bank (2001, Table 8.5) & Kazakhstan (1996) & 27.5 & 33.8 & 20.2 & \\
\hline Secondi (1997, p. 493) & Rural China (1988) & 26 & & & \\
\hline World Bank (2001, Table 8.5) & Russian Federation (1997) & 25.2 & 31.5 & 23.7 & \\
\hline Kochar (1997, p.342) & Rural North India (1981/82) & 20 (loans) & & & \\
\hline Khandker (1998, p. 114, 124) & Rural Bangladesh (1991/92) & $\begin{array}{c}15 \text { (gifts) } \\
17 \text { (loans) }\end{array}$ & & & \\
\hline World Bank (2001, Table 8.5) & Bulgaria (1995) & 17 & 21.4 & 15 & \\
\hline Foster and Rosenzweig (2001, Table 5) & Rural India (1976-1984) & & & & 100 \\
\hline Foster and Rosenzweig (2001, Table 5) & Rural Pakistan (1985-1988) & & & & 84 \\
\hline Cox $(2002$, p. 7$)$ & Vietnam (1992/93) & & & & 32.8 \\
\hline Cox (2002, p. 13) & Vietnam (1997/98) & & & & $\begin{array}{c}37.2 \text { (gifts) } \\
52.4 \text { (gifts \& loans) }\end{array}$ \\
\hline Foster and Rosenzweig (2001, Table 5) & Rural India (1968-1971) & & & & 8 \\
\hline
\end{tabular}

${ }^{1}$ All sources surveyed respondents about transfers over a 1 year period with the exception of Madagascar (2 year period), The Russian

Federation (30 days), Kazakhstan (30 days), and India and Pakistan (3 year period).

${ }^{2}$ Analysis covers both urban and rural areas unless otherwise noted

${ }^{3}$ Percentages refer to gifts unless otherwise noted

${ }^{4}$ Households in the lowest quintile of the per capita income distribution 


\section{B. The Relationship Between the Formal and Informal Sectors}

The literature highlights crowding out as the principal reason for being interested in the relationship between the formal and informal sectors, though the relationship also is relevant for program impacts. Knowledge of the relationship between the formal and informal sectors is relevant for researchers and policymakers interested in targeting program beneficiaries and measuring program impacts.

Crowding out occurs when increases in access to formal transfers and credit results in reductions in informal transfers and credit, or vice versa. Crowding out can have strong implications for targeting program beneficiaries. As Cox and Jimenez (1990) explain, if private donors cut back their informal transfers and credit as public formal transfers and credit increase, the effect of public programs on beneficiaries would be less than originally intended. If complete crowding out occurs, public programs would have no effect on targeted beneficiaries. With crowding out, some or all of the benefits of public formal transfer and credit programs would be shared with those who send private informal transfers and credit.

The complete crowding out view is more theoretical than practical. Even with complete income crowding out, programs may have important impacts on broader welfare measures. For example, programs that target women, such as microcredit programs, will likely impact female empowerment even in the absence of income impacts and government transfers may be preferred by some recipients to private transfers. Government transfers may also be more reliable and, in some cases, come with lower costs, such as less obligation to a more powerful relative or patron.

The informal sector and the relationship between the formal and informal sectors are also relevant to evaluating program impacts. As a result of crowding out, Cox and Jimenez (1990) suggest that examining only participating households may not adequately measure the full effects of public programs. Some of these effects may be indirectly shared with non-participating households. Morduch (1999) — in his literature synthesis on microfinance programs — states that "the extent of net impacts depends on the opportunities open to households in the absence of microfinance. Households that do not participate in microfinance programs may have access to a wide range of informal financial mechanisms..." (p. 1597). Given the importance of the relationship between the formal and informal financial sectors, what can the literature tell us about the relationship?

\section{Theory}

Theories on the relationship between the formal and informal financial sectors date back to the extensive literature on Ricardian equivalence started by Becker (1974) and Barro (1974) who argue that private transfers motivated by altruism could render formal transfers, such as social security programs, completely ineffective; if motivated by altruism, formal transfers and credit may completely crowd out informal transfers and credit. For example, if children care solely about their parents' well-being (i.e., are motivated only by altruism) and provide them with $\$ 500$ in informal transfers to ensure a constant income level, then a new formal program 
that provides $\$ 250$ in income to the parents (whether through formal transfers or credit) will reduce the informal transfers from the children by $\$ 250$, because the program will now help maintain the parents' constant income level. If informal transfers and credit are not motivated by altruism, but instead are motivated by exchange (e.g., in return for childcare) or self-interest (e.g., in return for inheritance), there will not be complete crowding out (Cox 1987).

Not surprisingly, given the importance of motivation for determining the outcome of formal transfer programs that redistribute income, a large literature subsequent to Becker (1974) and Barro (1974) examines motivations for transfers. Motivations examined include altruism versus self-interest or exchange, and insurance (e.g., transfers received in response to a natural disaster). The findings suggest no one clear motive for transfers. McGarry and Schoeni (1995a,b) find support for altruism. Lee, Parish and Willis (1994) and Secondi (1997) find support for altruism and some exchange. Altonji, Hayashi and Kotlikoff (1992) and Hayashi (1995) find evidence against pure altruism. Bernheim, Schleifer and Summers (1985), Cox (1987), Cox and Rank (1992) and Altonji, Hayashi and Kotlikoff (1996, 1997) find support for exchange motives. Knowles and Anker's (1981) findings are inconclusive; they do not find any significant correlation between size of financial assistance received and recipient's income. Lucas and Stark (1985), Rosenzweig and Stark (1989), Miller and Paulson (1999), Paulson (2000), and Clarke and Wallsten (2003) all find some evidence of insurance motives. McGarry (2000) concludes that our ability to distinguish empirically between altruistic and exchange behavior is severely limited.

Other non-motivation based theories also indicate no one clear direction for the relationship between the formal and informal sectors. These theories suggest that transfers may serve as a source of funds for those credit rationed (Cox and Jappelli 1990, Kochar 1997) or liquidity constrained (Cox 1990). Also, the entry of a subsidized program may worsen the terms and availability of loans offered by moneylenders (Hoff and Stiglitz 1998, Bose 1998, Jain 1999). While others describe cases in which increasing formal credit may improve availability in the informal sector (Floro and Ray 1997, Fuentes 1996). "Borrowers may be simultaneously active in both informal and formal markets, either because they are unable to get all the credit they need from one sector alone, or because formal lenders might condition their lending on the borrower's obtaining co-financing from other (presumably informal) sources" (Besley et al. 2001, p. 6). Empirical evidence is needed to sign the relationship between the formal and informal sectors.

In summary, seminal theoretical work in the literature suggests that the relationship between the formal and informal financial sector depends on motives. If transfers are altruistically motivated, then formal transfers may completely crowd out informal transfers. Yet the literature examining motivations for transfers indicates that transfers are rarely motivated by pure altruism, suggesting we should not expect 100 percent crowding out. What then is the empirical evidence on the relationship between the informal and formal sector? 


\section{Empirical Evidence}

Empirical evidence of the relationship between the formal and informal sectors is sparse. The majority of the literature is descriptive and focuses on the relative importance of the formal and informal sectors. The few studies that examine whether the formal sector crowds out the informal sector find some evidence of crowding out. There is little or no examination of the role that gender places in financial sector use or the relationship between the formal and informal sectors.

Descriptive empirical evidence on the relative importance of the formal and informal sectors is varied (Table 2). In Nepal, Besley et al. (2001) find that 82 percent of lending takes place in the informal sector and 12 percent in the formal sector. In Bangladesh, Khandker (1998) finds that the percentage of lending occurring in the informal sector dropped from 64 percent in 1985 to 34 percent in 1991/92. While in Vietnam, Cox (2002) finds that roughly one-third of lending takes place in the informal sector and two-thirds in the formal sector (p. 16). Part of the variation is likely due to country, region, time period and samples, but also to inconsistent definitions of the formal and informal sectors. For example, Cox (2002) defines loans from cooperatives and revolving credit organizations as formal, while Besley et al. (2001) and Khandker (1998) put them in a separate category. Redefining all institutional loans (those listed in the Formal and Other categories of Table 2) as formal begins to reconcile the differences between Rural Bangladesh (1991/92) and Vietnam (1997/98), but not between these countries and Nepal (1995/96). As a second example of differing definitions, Cox (2002) defines loans from moneylenders as formal or quasi-formal, while Besley et al. (2001) and Khandker (1998) consider them informal.

The World Development Report 2000/2001 further states that "informal and formal strategies are not independent: public policies and the availability of formal mechanisms heavily influence how extensively informal arrangements are used and which kinds are used" (World Bank 2001, p. 140). Sinha and Matin (1998) find that participants in NGO-operated microfinance programs in Bangladesh are often also active borrowers in the informal sector (as cited in Besley et al. 2001, p. 7).

Three studies we examine look at the effect of formal sector interventions on informal sector behavior. All three find some evidence that formal sector interventions crowd out informal sector finances. Rosenzweig and Wolpin (1994) find a small trade-off between government aid provided to young women in the form of welfare benefits and parental aid in the United States. Cox and Jimenez (1995) run simulations using data from the Philippines and find that public transfers crowd out private transfers. Interestingly, they find that crowding out may vary with the income of the targeted population. Persons in the second quartiles of the income distribution may be less affected by crowding out than other groups. Finally, Jensen (2003) finds that government old age pensions in South Africa crowd out private transfers. Each rand of public pension leads to a $0.25-0.30$ rand reduction in private transfers from children living away from home. 
TABLE 2 - The Relative Importance of Informal and Formal Sectors

\begin{tabular}{|c|c|c|c|c|c|c|c|}
\hline \multirow[b]{2}{*}{ Source } & \multirow{2}{*}{$\underset{\text { Year }^{1,2}}{\text { Country and }}$} & \multicolumn{3}{|c|}{ Percentage of Total Lending } & \multicolumn{3}{|c|}{ Definitions } \\
\hline & & Informal & Formal & Other & Informal & Formal & Other \\
\hline $\begin{array}{l}\text { Besley, Jain, and } \\
\text { Tsangarides (2001, p. 2) }\end{array}$ & Nepal (1995/96) & 82 & 12 & 6 & $\begin{array}{l}\text { Moneylenders, } \\
\text { landlords, } \\
\text { shopkeeper, } \\
\text { friends and } \\
\text { relatives }\end{array}$ & $\begin{array}{l}\text { Commercial and } \\
\text { agricultural development } \\
\text { banks }\end{array}$ & $\begin{array}{l}\text { Grameen-type banks, } \\
\text { ROSCA-type, local } \\
\text { groups, NGOs, relief, } \\
\text { other }\end{array}$ \\
\hline Khandker (1998, p. 112) & $\begin{array}{l}\text { Rural } \\
\text { Bangladesh } \\
(1987)\end{array}$ & 64 & 27 & 9 & $\begin{array}{l}\text { Moneylenders, } \\
\text { input dealers, } \\
\text { friends and } \\
\text { relatives }\end{array}$ & $\begin{array}{l}\text { Commercial and } \\
\text { agricultural development } \\
\text { banks }\end{array}$ & $\begin{array}{l}\text { Microcredit, } \\
\text { government } \\
\text { cooperative structures, } \\
\text { NGOs }\end{array}$ \\
\hline Khandker (1998, p. 114) & $\begin{array}{l}\text { Rural } \\
\text { Bangladesh } \\
(1991 / 92)\end{array}$ & 34 & 21 & 45 & $\begin{array}{l}\text { Moneylenders, } \\
\text { input dealers, } \\
\text { friends and } \\
\text { relatives }\end{array}$ & $\begin{array}{l}\text { Commercial and } \\
\text { agricultural development } \\
\text { banks }\end{array}$ & $\begin{array}{l}\text { Microcredit, } \\
\text { government } \\
\text { cooperative structures, } \\
\text { NGOs }\end{array}$ \\
\hline Cox (2002, p. 16) & $\begin{array}{l}\text { Vietnam } \\
(1997 / 98)\end{array}$ & 33 & 67 & & $\begin{array}{l}\text { Relatives, friends, } \\
\text { and neighbors }\end{array}$ & $\begin{array}{l}\text { Banks, gov't credit } \\
\text { programs, cooperatives, } \\
\text { revolving credit, or } \\
\text { moneylenders }\end{array}$ & \\
\hline Zeller (1994, p. 6-9) & $\begin{array}{l}\text { Rural } \\
\text { Madagascar } \\
1992\end{array}$ & 52 & 48 & & $\begin{array}{l}\text { Relatives, friends, } \\
\text { informal self-help } \\
\text { groups, and other } \\
\text { unregulated loans }\end{array}$ & $\begin{array}{l}\text { NGOs, gov't extensions of } \\
\text { commercial and } \\
\text { agricultural development } \\
\text { banks, parastatal or private } \\
\text { agribusiness firms }\end{array}$ & \\
\hline Kochar (1997, p. 344) & $\begin{array}{l}\text { Rural North } \\
\text { India }(1981 / 82)\end{array}$ & 58 & 42 & & $\begin{array}{l}\text { Other farmers, } \\
\text { relatives, friends, } \\
\text { landlords, traders, } \\
\text { and moneylenders }\end{array}$ & $\begin{array}{l}\text { Banks and government } \\
\text { programs }\end{array}$ & \\
\hline
\end{tabular}

${ }_{2}^{1}$ All sources surveyed respondents about transfers over a 1 year period, with the exception of Madagascar (2 year period) and Bangladesh $1991 / 92$ ( 6 year period).
2 Analysis covers both urban and rural areas unless otherwise noted. 


\section{Reasons for Targeting Women with Transfers and Credit}

The literature highlights four key reasons for targeting women with transfers and credit: financial advantages, reaching a more vulnerable population, empowerment, and better program impacts.

Lending to women appears to have financial advantages to lending to men (Morduch 1999, p. 1583). Women appear to have higher loan repayment rates (Khandker 1998, p.100). Women's lower mobility may play a role in financial advantages if there is a fear that borrowers will default, move, and borrow in a new location (Morduch 1999, p. 1583). Also, women may have fewer alternatives for borrowing and thus be less likely to default where defaulting results in loss of access to future, potentially larger loans - as is the case in the incentive schemes used by many microfinance programs.

Since women have fewer alternatives for borrowing, they are a more vulnerable population and especially good candidates for formal credit programs. The World Development Report 2000/2001 finds that "Microfinance programs have been especially important for women and households headed by women, who often have difficulty getting credit" (World Bank 2001, p. 156). But if access to credit is the only reason to target women then, as Rashid and Townsend (1994) point out, why don't men in the household borrow for women?

Two additional reasons to target women are empowerment and better program impacts. The share of household market income earned by women is likely to enhance their bargaining power in the household vis-à-vis men. Citing earlier research, Khandker (2003, p. 4) finds "that women do acquire assets of their own and exercise power in household decision-making." However, there is some debate as to whether loans made to women remain in the control of women. Estimates of the percent of female Grameen Bank borrowers that retain control over their loan range from 37 percent (Goetz and Sen Gupta 1996) to 63 percent (Hashemi, Schuler and Riley 1996), as cited in Morduch (1999).

Empowering women within the household can lead to better program impacts as a result of "maternal altruism"- women are presumed to desire smaller family sizes, greater investments in the health and schooling of children, and greater gender equality in intra-household allocation than men. ${ }^{2}$ Increasing women's bargaining power is likely to lead to resource allocations more in line with women's desires.

These gender differences are important. Thomas (1997, p. 143) finds that placing more resources in the hands of women results in greater spending on human capital and nutrients and better child nutrition outcomes. Earlier work with the data analyzed below-Pitt and Khandker (1998), Pitt, et al. (1999), Pitt, et al. (2003), Pitt (2001) - has found that the effects of program participation differ importantly by the gender of program participant. For example, Pitt and Khandker (1998) find that the flow of consumption expenditure increases by 18 Taka for every

\footnotetext{
${ }^{2}$ See Intrahousehold Resource Allocation in Developing Countries: Models, Methods, and Policy by Haddad, Alderman, and Hoddinot (1997) for a survey of this literature.
} 
100 Taka borrowed by women, but only by 11 Taka for every 100 Taka borrowed by men. Pitt et al. (2003), using a totally different approach, find that credit provided women importantly improves measures of health and nutrition for both boys and girls, while credit provided men has no significant effect. As Thomas (1997, p. 142) explains, rejection of the traditional unitary household model has strong implications for public policy. It suggests, for example, that policies that provide more resources to women will have different effects on household choices than policies that provide resources to men. Empirical evidence rejects the unitary model (Haddad, Alderman and Hoddinot 1997b). Evidence that women use resources differently than men suggests that it is important to analyze the relationship between the formal and informal financial sectors by gender.

\section{The Bangladeshi Context}

Gender differences are particularly important in the Bangladeshi context where men and women live within separate spheres. Bangladesh is a traditional Muslim society where men yield disproportionate power, in part as a result of purdah. Purdah is a complex set of norms that dictate a woman's conduct toward her husband and other men. Its practice in Bangladesh means that a woman avoids direct eye-contact with and speaks quietly in the presence of men, may cover her face when talking with men or senior relatives, rarely leaves the confines of her homestead, and if compelled to leave, avoids places frequented by men (Shehabuddin 1992), among other restrictions.

As a result of purdah, women are less likely to be educated or work for a wage. A woman's primary destiny is to marry. Once married, typically at a young age, a woman moves to her husband's extended household in a village where she is a stranger. If she bares sons, who can provide future income to the household, her low position within the extended household improves. If she fails to produce sons, she faces the threat of desertion or divorce (Shehabuddin 1992, 95). Women's work consists primarily of non-agricultural production that can be carried out at the homestead, housework, and childcare (Shehabuddin 1992, 61). Without access to wage labor, a woman alone has few means to provide for her family. Household income in rural areas comes largely from men and is roughly split between agricultural (subsistence and wages) and non-agricultural sources (World Bank 2002, 20).

The four key reasons for targeting women with credit and transfers-financial advantage, reaching a vulnerable population, empowerment, and better program impacts - especially apply in Bangladesh. Low mobility and little interaction with men mean Bangladeshi women have fewer alternatives for borrowing and thus potentially greater returns from borrowing and higher loan repayment rates, consequently providing financial advantage. Little access to the wage labor market makes Bangladeshi women, especially those widowed or divorced, vulnerable.

Purdah and women's inability to bring income to the family mean that women have little power within the household, making Bangladeshi women especially good candidates for empowerment. We know from the description of purdah's practice in Bangladesh that women have little social power. But what about economic power? Economic decision-making is 
subjective and difficult to measure. However, empirical evidence from rural Bangladesh finds that roughly half of women respondents answer that they jointly decided on and implemented economic issues with their husband. The other half answered that the couple decided jointly and the husband implemented alone, or the husband decided and implemented alone (Pitt, Khandker and Cartwright 2003, 8).

Does it help to provide women with credit and transfers if women can't fully control how they are used? Recent evidence suggests that participating in microcredit programs increases women's empowerment. Pitt, Khandker, and Cartwright (2003) find that credit program participation leads to women taking a greater role in household decision making, having greater access to financial and economic resources, having greater social networks, having greater bargaining power vis-à-vis their husbands, and having greater freedom of mobility (p. 30).

Credit provided to women in Bangladesh has been shown to have better impacts than credit provided to men, as cited in Section $\mathrm{C}$ above. The gender differences may be especially strong with microcredit because purdah restricts women's access to the wage labor market. Providing small loans to women enables them to undertake self-employment activities in the seclusion of their homes, thus providing paid income in a manner less culturally frowned upon. Microcredit programs thus provide a large change in paid income, moving women from the corner of essentially zero income to a positive amount.

\section{E. Our Contributions to the Literature}

Based on the literature, we know that the importance of the informal financial sector varies by country, that the relationship between the formal and informal sectors is important, and that motives for transfers predict the relationship between the formal and informal sectors, yet motives appear to be mixed. There is little empirical evidence on the relationship between the formal and informal sectors, especially by gender. Gender is important because programs target women and often have different impacts when women participate than when men participate.

This report will contribute to the literature by examining the role that the formal and informal financial sectors play for households in rural Bangladesh and how that role varies by gender. It will also contribute to the literature by measuring the relationship between the formal and informal sectors by gender and whether formal microcredit (by gender) crowds out informal inter-household transfers. 


\section{Section III. Data and Definitions}

\section{A. Data}

We empirically describe the formal and informal sectors in Bangladesh using panel data from the World Bank/Bangladesh Institute of Development Studies' Credit Programs for the Poor survey. The Credit Programs for the Poor survey includes panel data on approximately 1,800 households from 87 villages in rural Bangladesh. ${ }^{3}$ The first wave of the panel was collected in 1991/92 and the second wave in 1998/99. The survey is well suited to analyzing the formal and informal financial sectors as it includes detailed information on money borrowed, lent, and transferred from many sources, and a wide variety of household characteristics.

The survey is nationally representative of rural Bangladesh. Rural Bangladesh is home to 80 percent (101 million people) of the country's population and 85 percent of the citizens living in poverty. The rural poverty rate in 2000 was 53 percent with 37 percent living in extreme poverty (World Bank 2002,4). The typical household consisted of between five and six household members. The majority of individuals in rural Bangladesh are illiterate (59 percent) and 54 percent of 11-19 year-olds have completed the $5^{\text {th }}$ grade (World Bank 2002, 12, 45).

One drawback of the survey is its lack of information regarding transfers from formal institutions. The Bangladeshi government transferred over $\$ 300$ million in benefits during fiscal year 1999 (World Bank 2002, 67). Most of Bangladesh's social safety net expenditures (95 percent) go to targeted food transfer programs. However, these food programs do not provide pure formal transfers. Most of the food allocated through these programs (86 percent) is provided in return for work, education, or training. The survey likely captures food for work as part of in-kind income from employment, but we are unable to separate the Food for Work transfers from other in-kind payments. As the survey did not specifically ask about formal transfer program receipt, the Food for Education and food for training (Vulnerable Group Development) transfers likely went uncaptured. Throughout the results, we briefly discuss how ignoring formal transfers might affect our conclusions. Although the survey lacks details on participation in formal transfer programs, it does provide thorough information on formal lending and informal gifts and loans.

The survey was designed for use in evaluating three flagship microcredit programs in Bangladesh: the Bangladesh Rural Advancement Committee (BRAC), the Bangladesh Rural Development Board's (BRDB) RD-12 program, and the Grameen Bank. It was designed quasiexperimentally to include both target (qualify to participate) and non-target (do not qualify to participate) households from both program and non-program villages. This quasi-experimental aspect of the survey is important in our current and future work causally examining the relationship between formal credit from microcredit programs and informal transfers and credit.

\footnotetext{
${ }^{3}$ The second wave of the survey includes a total of 104 villages. Nine villages were added from thanas in the southeastern region of Bangladesh that was severely hit by a cyclone during the first wave. Eight additional villages were added from thanas included in the first wave.
} 
The survey sample design is choice-based: a stratified random sampling technique was used to over-sample households participating in one of the three credit programs and target nonparticipating households. Throughout the analysis we use weights, based on the population and sample distributions of households covered in the study villages, to weight the choice-based sample back to random sample proportions. ${ }^{4}$

Wave 1: Interviews for the first wave of the survey took place from December 1991 through December 1992. The wave 1 survey was conducted three times over the year at periods coinciding with the three cropping seasons in Bangladesh. In the first round of the survey, 1,798 households were interviewed. In the second and third rounds, 1,778 and 1,769 of these households were re-interviewed respectively. Households were asked about informal transfers over the past four months rather than the past year. By combining the three rounds of data, we are able to measure informal transfers received and sent over the past year. Though credit data (money borrowed and lent) are available over the past six years, we truncate the period to the past year in order to coincide with the transfer data. ${ }^{5}$

Wave 2: Interviews for the second wave of the survey took place from February through October 1999. The wave 2 survey was conducted once and asked about informal transfers over the past year. Again, we restrict the available credit data to the same time period as the informal transfer data. A total of 2,623 households were interviewed in wave 2 of the data. These households include 1,667 original households from the first wave, 317 households that split off from original households, and 639 new households from both new and old villages. ${ }^{6}$ A total of 117 households that are included in our first wave analysis did not participate in the second wave of the survey.

Three important contextual changes took place between the first and second survey waves. First, there was substantial economic growth in Bangladesh. The gross domestic product averaged 4.8 percent annual growth between 1990 and 1999, which amounts to a 52 percent increase in GDP over the time period (World Bank 2001). At the same time, the rural poverty rate dropped from 61 percent in 1991/92 to 53 percent in 2000 (World Bank 2002). Bangladesh also made substantial strides in school attendance, nutrition, and saw various improvements in health indicators.

The second important contextual change between survey waves is that there was a significant rise in the number of microcredit organizations in rural Bangladesh, an increase that

\footnotetext{
${ }^{4}$ The weights for the second wave of the survey are imperfect. The population distribution of households is not available for the second wave and is estimated using the population distribution from the first wave.

${ }^{5}$ Khandker (1998) also uses the first wave of the World Banks/BIDS survey in his analysis of microcredit in Bangladesh. Because Khandker's focus is only on credit, he includes all six years of loan data, which leads to significant differences between estimates in his book and ones included in our descriptive analysis. To effectively measure the importance of gifts versus loans, our focus, it is important to limit both to the same timeframe.

${ }^{6}$ Fourteen households in the second wave were included in the first wave but did not complete all three interviews. Thus, those households are not included in our analysis of the first wave but are part of the second wave study. Additionally, one household in the second wave is documented as being an original first wave household, however its identification number does not match any households in the first wave. This leaves 1,652 households for which longitudinal data are available.
} 
is well documented in the survey data. Today Bangladesh has the largest operation of microcredit programs in the world, with about 12.4 million active borrowers and over 629 NGOs engaged in microcredit (World Bank 2003, 21). Additionally, there was an increase in the size of several of the previously existing microcredit institutions. For example, the Grameen Bank grew from 1.1 million members in 25,248 villages in 1991 to 2.4 million members in 39,706 villages in 1999 (Grameen Bank 2004).

The third important contextual change is that the second survey wave occurred during the massive 1998 flooding which greatly affected large areas of rural Bangladesh. Without a doubt, the flooding affected the transfer and credit behavior of rural Bangladeshi families. We note various implications of the flooding in more depth throughout the report.

Attrition Bias: The Credit Programs for the Poor survey was quite successful in keeping attrition of the sample to a very low level of 7.4 percent. Econometric tests for attrition bias reported in Khandker and Pitt (2002) find scant evidence of any bias. One test performed by Khandker and Pitt suggesting that attrition bias is not a significant issue with these data regressed outcome variables on household-level exogenous variables (among them age, sex and education of household head, maximum education of household males and household females, land ownership), a dummy variable indicating whether the household was not in the second round survey, and interactions of that attrition dummy and all the exogenous variables. These findings are consistent with other studies on household attrition using U.S. and other data.

Household-level Analysis: We conduct the large majority of the analysis at the household-level for two primary reasons. First, individual-level observations are not independent because only one member of a household may participate in several of the key formal credit sources in Bangladesh (e.g., Grameen Bank). As a result, other household members would have zero probability of receiving formal credit. Second, finances within gender in the household are likely fungible. A formal loan given to one male (female) in the household may have a similar affect on private transfers as a formal loan given to another male (female). As the primary focus is between genders rather than within gender, we aggregate loans and transfers by gender within the household. As a result, most gender-specific measures are also at the household level. For example, formal loans to females would be the sum of all formal loans received by any female in the household. Where noted, we do limited individual-level analysis to further examine the characteristics of recipients and sources of senders.

Throughout the survey, the questionnaire asks for the person who was the "primary" recipient or sender of each gift or loan. Our gender analysis is performed based on this response, however, gifts and loans may be shared by several individuals in the household. While the majority of our analysis uses the gender of the primary sender and recipient as reported by the respondent, we do investigate whether the gender results are sensitive to this reporting. These results are reported in our section on the Role of the Formal and Informal Sectors by Gender. 


\section{B. Variable Definitions}

Below we briefly summarize important variable definitions and assumptions used in the study. Throughout the analysis, data on gifts and loans, both formal and informal, are limited to the past year. We broadly define formal gifts and loans as those from institutions and informal gifts and loans as those from individuals. The specific sources for the formal and informal sectors are detailed below. Because this is a multi-year analysis, we convert all monetary variables into real 1995 Taka using a Consumer Price Index for Bangladesh to allow for crossyear comparisons (World Bank, World Development Indicators database). While inflation has not been extremely high in Bangladesh, one Taka in 1991 is equivalent to roughly 1.38 Taka in 1998. In 1995, the average exchange rate was 40.278 Taka per U.S. dollar (U.S. Department of Commerce, International Trade Administration).

Informal Transfers and Credit Sent and Received: Gifts and loans from relatives, neighbors, friends, moneylenders, employers, landlords, and shopkeepers are defined to be from the informal sector. Remittances sent from abroad are also considered informal transfers. Our variables measuring the informal sector, also referred to as informal gifts and loans or transfers and credit, measure the cumulative amount of all gifts and loans received (or sent) during the past year. These gifts and loans may include cash and the value of all food and other in-kind assistance. While there is no minimum gift value, loans must be at least 1,000 (nominal) Taka to be included in the survey. ${ }^{7}$

Unlike formal transfers and credit, whether informal money received or sent is termed a gift or loan is subjective, especially when the money comes from a relative. For example, when a parent gives money to a son it may be called a gift, but when the same parent gives money to a daughter it may be called a loan. Even when money is given as a gift, the sender may expect to be repaid in-cash or in-kind. Our descriptive results, as described below, highlight the fluid interpretation of gifts versus loans. We analyze informal gifts and loans separately in the descriptive analysis. In the regression analysis, where we more narrowly focus on interhousehold transfers, we combine gifts and loans from relatives because whether the amount received (or sent) is termed a gift or loan is fluid and open to interpretation.

Informal Transfers and Credit Sent to and Received from Relatives and Non-Relatives. Gifts and loans sent to and from relatives are defined to be from the informal sector. Relatives sending or receiving transfers may include parents, children, siblings, in-laws, and other relatives such as aunts, uncles, and cousins. Transfers and credit from non-relatives may include friends, neighbors, moneylenders, employers, input suppliers, and shopkeepers. Again, all gifts and loans must have occurred during the past year.

Formal Sector/Formal Credit Received: Loans from microcredit organizations, government institutions, commercial banks, cooperatives, and other NGOs are defined to be

\footnotetext{
${ }^{7}$ A total of six loans less than $1,000 \mathrm{Tk}$. were included in the first wave of the survey. However, the documentation cites that there is a 1,000 Tk. loan minimum, and thus we have removed those loans from our analysis. This 1,000 Tk. minimum may lead to a slight underestimate of total lending during the first wave since loans had to be relatively larger to be included in the 1991/92 survey than in the 1998/99 survey when accounting for inflation.
} 
from the formal sector. Our formal sector variables capture the cumulative amount of all loans (greater than or equal to 1,000 Tk.) received in the past year.

Formal Program Credit and Total Microcredit: Formal program credit captures the cumulative amount of all loans (greater than or equal to 1,000 Tk.) received in the past year from one of the three primary microcredit programs, BRAC, BRDB, and Grameen Bank. Total microcredit includes this program credit as well as microcredit from the following additional sources: ASA, Proshika, GSS, Youth Development, and other NGO's. These additional microcredit sources were documented in wave 2 of the survey only (with the exception of the broad category other NGO's in wave 1).

Formal Government and Non-Government Credit: Formal government credit captures all loans from government institutions such as the Krishi Bank and BSCIC as well as other government agencies. Non-government credit is the cumulative amount of loans from all commercial banks and cooperatives. The combined loans from these sources are referred to as other credit throughout the analysis. 


\section{Section IV. Descriptive Results}

Households in rural Bangladesh rely on both the formal and informal financial sectors for access to money through transfers and credit. These financial sectors are sizeable with nearly half of all households receiving a gift or loan in the past year. In this section, we outline important characteristics about the formal and informal sectors, emphasizing gender-related differences and looking at the development of both sectors during the 1990's.

\section{A. The Relative Importance of the Formal and Informal Financial Sectors}

Descriptive results indicate that the informal sector was at least as important as the formal sector in Bangladesh during the 1998/99 time period (Table 3). Slightly more households received money from the formal sector ( 29 percent) than from the informal sector ( 24 percent, not shown). However, the average size of informal gifts and loans received was significantly larger than the average size of formal loan received, highlighting their relative importance. Most of this difference was due to informal gifts, which averaged nearly three times the size of average formal loans. However, the average informal loan value was also greater than the average formal loan value. The informal sector (loans and gifts) accounted for 68 percent of the average total value of household loans and gifts received while the formal sector accounted for only 32 percent (Table 3 ).

Though the survey does not include information on formal transfers received, we can roughly estimate that the average household likely received 700 Taka in formal transfers in 1998/99. ${ }^{8}$ According to the survey data, the average household received 2,125 Taka in formal loans, 1,440 Taka in informal loans, and 3,040 Taka in informal gifts. Thus, formal transfers are not inconsequential, however they appear to be smaller than formal loans and informal gifts and loans. Furthermore, including estimated formal transfers still leaves the informal sector larger than the formal sector (61 versus 39 percent).

The limited international comparisons available suggest that fewer households participated in the informal sector in rural Bangladesh (24 percent) over the surveyed year than in most other countries (Table 1). For example, 96 percent of households received informal loans over the past two years in Madagascar, 89 percent of households received informal transfers over the past year in rural Philippines, and 26 percent of households received informal

\footnotetext{
${ }^{8}$ Using information from the Bangladesh Ministry of Finance, the total size of safety net programs was 19,878 million Taka in the 2001-02 government budget. Assuming that the aid is distributed based on the existence of poverty, roughly 85 percent of the aid should go to rural areas. With a rural population of 101 million people, the average person would receive 167 Taka in formal transfers and the average household (with approximately 5.5 people) would receive 920 Taka in aid. Converting this value to 1995 Taka, we estimate that the average household received around 710 Taka in formal transfers. This number may be slightly low for 1998/99 because of the increased formal transfers due to the flooding that ravaged much of Bangladesh. However, at the same time, the estimate may be high because the budget is based on the costs of the program, which likely include considerable administrative costs. All of these data come from Poverty in Bangladesh: Building on Progress published by the World Bank (2002, report number 24299-BD).
} 
TABLE 3 - Sources of Gifts and Loans Received, 1998/99

\begin{tabular}{|c|c|c|c|c|c|c|}
\hline & \multirow[b]{2}{*}{$\begin{array}{l}\% \text { Households } \\
\text { Received } \\
\text { (1) }\end{array}$} & \multicolumn{2}{|c|}{ Amount Received } & \multirow[b]{2}{*}{$\begin{array}{l}\% \text { of Total Gifts } \\
\text { and Loans in } \\
\text { Category } \\
\text { (4) }\end{array}$} & \multirow[b]{2}{*}{$\begin{array}{c}\% \text { of Total Gifts } \\
\text { and Loans } \\
\text { Received }^{2} \\
(5)\end{array}$} & \multirow[b]{2}{*}{$\begin{array}{l}n^{3} \\
(6)\end{array}$} \\
\hline & & $\begin{array}{c}\text { Mean }^{1} \\
(2)\end{array}$ & $\begin{array}{l}\text { Standard } \\
\text { Error } \\
(3)\end{array}$ & & & \\
\hline Informal Gifts & 14.6 & 20,879 & 1878 & 100.0 & 46.1 & 346 \\
\hline Relative Gifts & 14.6 & 20,879 & 1878 & 100.0 & 46.1 & 346 \\
\hline Spouse & 2.7 & 31,840 & 4376 & 27.8 & 12.8 & 67 \\
\hline Child & 7.6 & 18,777 & 2564 & 46.9 & 21.6 & 177 \\
\hline Parent & 1.2 & 22,941 & 7793 & 8.7 & 4.0 & 29 \\
\hline Sibling & 1.7 & 16,547 & 5369 & 9.0 & 4.2 & 41 \\
\hline In-law & 0.9 & 11,356 & 7635 & 3.3 & 1.5 & 19 \\
\hline Other & 0.6 & 12,838 & 7294 & 2.4 & 1.1 & 13 \\
\hline Informal Loans & 12.7 & 11,339 & 2335 & 100.0 & 21.8 & 297 \\
\hline Relative Loans & 5.6 & 15,560 & 4455 & 60.5 & 13.2 & 127 \\
\hline Parent & 0.1 & 3,968 & 1311 & 0.2 & 0.0 & 4 \\
\hline Child & 0.1 & 16,848 & 8812 & 1.6 & 0.3 & 5 \\
\hline Sibling & 1.3 & 20,015 & 8680 & 17.8 & 3.9 & 26 \\
\hline Mother/Father-in-law & 1.0 & 27,592 & 10395 & 18.4 & 4.0 & 14 \\
\hline Other Relative & 4.2 & 7,833 & 1906 & 22.6 & 4.9 & 92 \\
\hline Non-Relative Loans & 8.6 & 6,563 & 1065 & 39.2 & 8.5 & 203 \\
\hline Friends & 1.4 & 4,551 & 1058 & 4.6 & 1.0 & 37 \\
\hline Neighbors & 3.4 & 4,538 & 858 & 10.7 & 2.3 & 81 \\
\hline Moneylenders & 2.4 & 5,444 & 1434 & 8.9 & 1.9 & 58 \\
\hline Other Non-Relatives & 2.4 & 8,569 & 3124 & 14.4 & 3.1 & 57 \\
\hline Formal Loans & 29.3 & 7,254 & 298 & 100.0 & 32.1 & 973 \\
\hline All Microcredit & 26.4 & 6,700 & 199 & 83.1 & 26.7 & 904 \\
\hline Program Loans & 18.3 & 7,521 & 250 & 64.7 & 20.8 & 684 \\
\hline BRAC & 5.0 & 4,920 & 293 & 11.6 & 3.7 & 158 \\
\hline BRDB & 1.7 & 6,209 & 714 & 5.0 & 1.6 & 56 \\
\hline GB & 12.0 & 8,508 & 323 & 48.1 & 15.5 & 488 \\
\hline Other Microcredit & 9.1 & 4,300 & 251 & 18.4 & 5.9 & 248 \\
\hline Other Formal Loans & 3.8 & 9,502 & 1728 & 17.0 & 5.5 & 96 \\
\hline Government & 1.8 & 7,904 & 740 & 6.9 & 2.2 & 49 \\
\hline Non-Government & 2.2 & 9,764 & 2593 & 10.2 & 3.3 & 53 \\
\hline
\end{tabular}

Source: Authors' tabulations from the 1998/99 World Bank/BIDS survey of rural Bangladesh.

General Notes: Weights are used to adjust the choice-based sample to random sample proportions. Columns may not add up due to rounding. Please see text for detailed category definitions.

${ }^{1}$ Mean provides the average cumulative amount (in 1995 Taka) that a household received, for households with non-zero values. Average 1995 Tk./U.S. \$ exchange rate is 40.278.

${ }^{2}$ Percentages are calculated based on the total value received (accounting for the percentage of households receiving and average amount received).

${ }^{3} \mathrm{n}$ provides the unweighted number of households who received the specified gift or loan. 
transfers over the past year in rural China. This is interesting, given the relative importance of the informal sector in Bangladesh.

Consistent with the literature, the descriptive results further indicate that households are more likely to receive than send informal gifts and loans. The difference is especially large with respect to informal gifts; roughly 15 percent of households received informal gifts while only two percent sent them (Figure 1). Households were also more likely to receive than send informal loans, though the receiving/sending gap was smaller for informal loans than gifts. In addition, the average sizes of both informal gifts and loans sent were significantly smaller than the average sizes of those received (Figure 1).

Figure 1. Informal Gifts and Loans Sent and Received, 1998/99

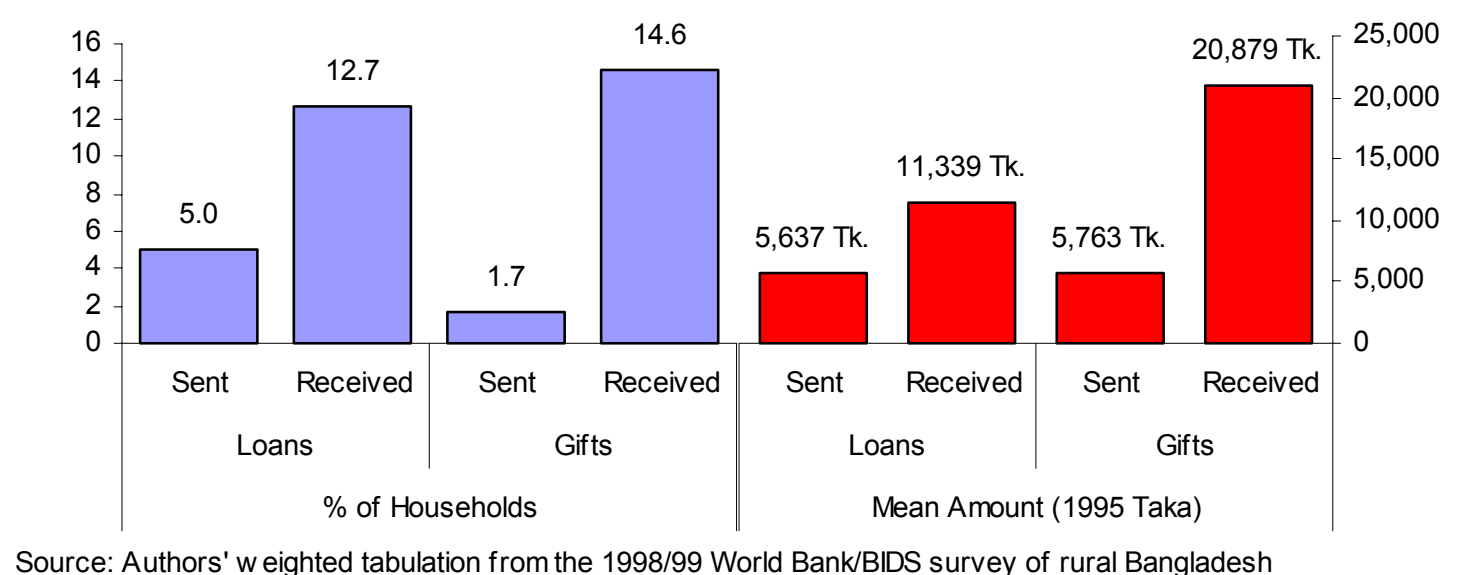

Source: Authors' w eighted tabulation from the 1998/99 World Bank/BIDS survey of rural Bangladesh

The difference between the overall size of gifts and loans sent and received is largely due to the rural sample population in the survey. Figure 2 shows that households in this rural sample received the majority of their informal gifts in the form of remittances from abroad and from donors in urban areas of Bangladesh. Rural gifts amounted to only three percent of the total value of informal gifts received compared with 71 percent from abroad and 24 percent from urban areas. At the same time, there was not a single observation of a gift sent abroad, and the few gifts that were sent were split relatively evenly between rural and urban areas (not shown). This flow of informal transfers to rural areas from urban areas is not surprising. Cox (2002) also finds some evidence of this type of urban-rural informal sector relationship in his study of Vietnam.

The flooding that occurred during the year of the survey may have also lead to increased gifts and loans received and decreased gifts and loans sent. Compared with the 1991/92 survey, informal gifts and loans sent dropped significantly in 1998/99. However, informal gifts and loans sent were substantially lower than those received in both survey waves. Because so few households sent informal gifts and loans in rural Bangladesh, we focus almost entirely on gifts and loans received for the remainder of this report. 
Figure 2. Informal Gifts by Location of Source, 1998/99
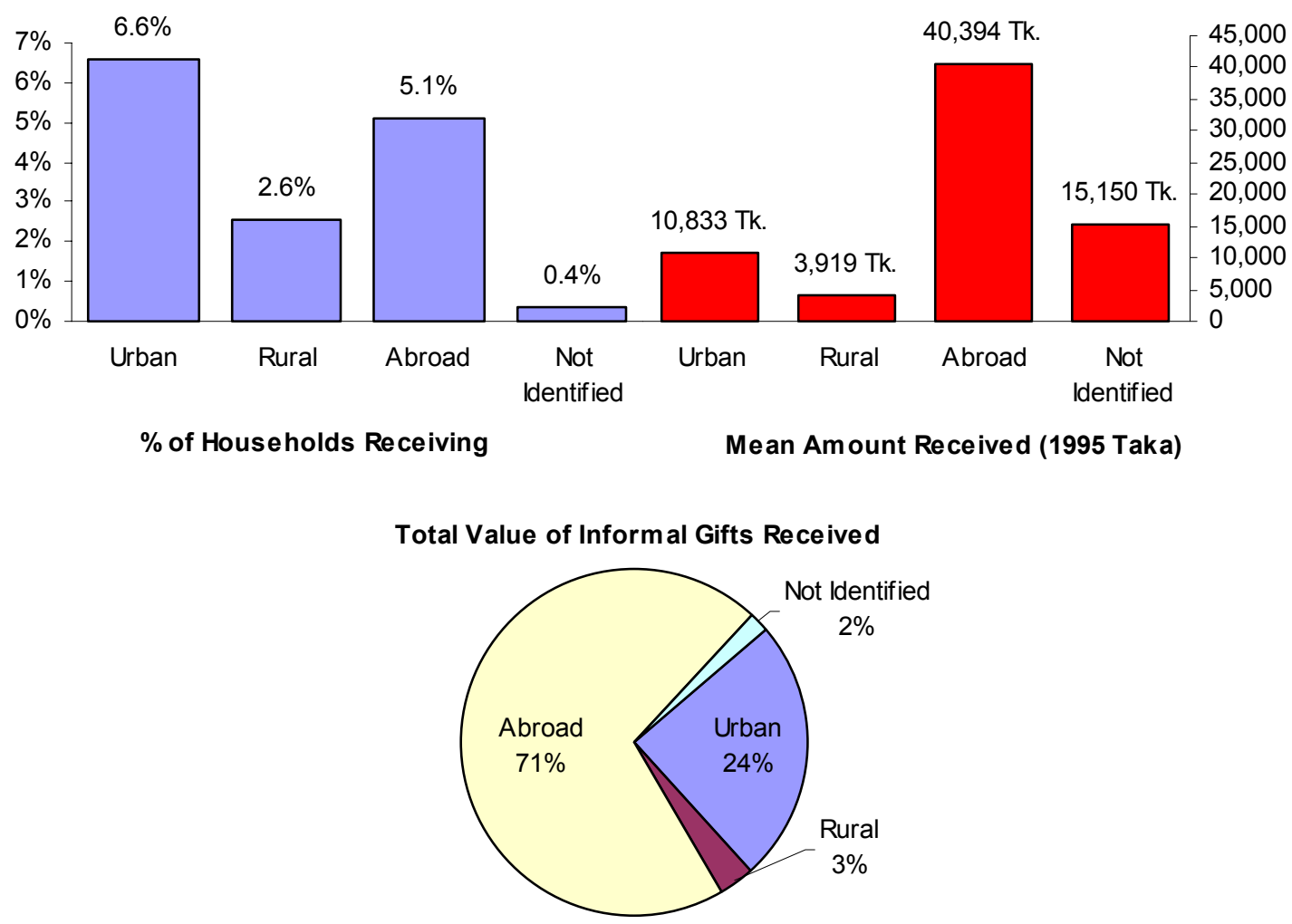

Source: Authors' w eighted tabulation from the 1998/99 World Bank/BIDS survey of rural Bangladesh

\section{B. Household and Individual Characteristics of Recipients ${ }^{9}$}

Household Characteristics: Surprisingly, there are few differences between the average demographic characteristics of households who do (recipient) and do not (non-recipient) receive any type of gifts or loans (Table 4). Differences only begin to emerge when we look at the specific types of gifts or loans received, however even these differences are fewer and smaller than might be expected. Households receiving informal loans have higher incomes $(25,583 \mathrm{Tk}$.) on average than non-recipients $(22,620 \mathrm{Tk}$.) and recipients of other types of loans or gifts. Households receiving informal gifts tend to be lower-income, more likely to be female headed, without a spouse, older, and more educated, on average.

The demographic similarities between recipient and non-recipient households and average income differences between households receiving informal gifts and households receiving informal loans are further confirmed in Table 5, which shows the share of gifts and loans received by income quintile. While non-recipient households were spread relatively evenly through all income quintiles, over half (57 percent) of all households that received informal gifts were in the bottom two income quintiles, and half of all households that received informal loans were in the top two income quintiles. Table 5 also appears to partially confirm a

\footnotetext{
${ }^{9}$ As cell sizes get small in our analysis of household and individual characteristics, our ability to detect statistically significant differences becomes weak. Many of the differences discussed in this section are not statistically significant.
} 
common criticism of microcredit: that it does not reach the poorest of the poor. Households in the top two income quintiles were the most likely to receive microcredit loans while households in the bottom quintile were the least likely to receive them. Still, Table 5 confirms that households from all quintiles of the income distribution are formal sector recipients, informal sector recipients, and non-recipients.

TABLE 4 - Characteristics of Loan or Gift Recipient and Non-Recipient Households by Gender, 1998/99

\begin{tabular}{|c|c|c|c|c|c|}
\hline & \multirow[b]{2}{*}{$\begin{array}{c}\text { Non-Recipient } \\
\text { Household }^{2}\end{array}$} & \multicolumn{4}{|c|}{ Households that received: } \\
\hline & & $\begin{array}{l}\text { Any type of } \\
\text { gift or loan }\end{array}$ & $\begin{array}{c}\text { Formal } \\
\text { Loan }\end{array}$ & $\begin{array}{c}\text { Informal } \\
\text { Loan }\end{array}$ & $\begin{array}{c}\text { Informal } \\
\text { Gifts }\end{array}$ \\
\hline \multicolumn{6}{|l|}{ Male or Female Recipient } \\
\hline Percent Male Head & $88.9 \%$ & $87.9 \%$ & $89.8 \%$ & $90.2 \%$ & $77.9 \%$ \\
\hline Percent No Spouse Present & $15.3 \%$ & $13.6 \%$ & $11.1 \%$ & $12.6 \%$ & $23.9 \%$ \\
\hline Mean Pre-Transfer Income (1995 Taka) & 22,620 & 22,468 & 22,671 & 25,583 & 19,839 \\
\hline Mean Age of Head & 44.9 & 46.7 & 44.9 & 46.1 & 52.9 \\
\hline Mean Education of Head & 2.5 & 2.6 & 2.2 & 3.0 & 3.3 \\
\hline Mean Max Age of Females & 40.9 & 43.4 & 41.5 & 42.9 & 49.5 \\
\hline Mean Max Age of Males & 42.0 & 44.1 & 42.6 & 44.7 & 47.6 \\
\hline Mean Max Education of Females & 2.6 & 2.9 & 2.3 & 3.3 & 4.3 \\
\hline Mean Max Education of Males & 3.8 & 4.5 & 3.7 & 5.4 & 6.4 \\
\hline Mean Household Size & 5.0 & 5.5 & 5.3 & 6.1 & 5.8 \\
\hline Observations $^{1}$ & 1245 & 1378 & 973 & 297 & 346 \\
\hline \multicolumn{6}{|l|}{ Female Recipient } \\
\hline Percent Male Head & $91.0 \%$ & $82.2 \%$ & $88.2 \%$ & $75.1 \%$ & $48.1 \%$ \\
\hline Percent No Spouse Present & $13.1 \%$ & $17.8 \%$ & $12.9 \%$ & $32.1 \%$ & $46.8 \%$ \\
\hline Mean Pre-Transfer Income (1995 Taka) & 22,474 & 22,724 & 23,225 & 29,664 & 17,976 \\
\hline Mean Age of Head & 46.2 & 44.7 & 44.6 & 45.0 & 45.6 \\
\hline Mean Education of Head & 2.7 & 2.1 & 1.9 & 2.7 & 3.1 \\
\hline Mean Max Age of Females & 42.3 & 41.7 & 40.8 & 44.9 & 45.7 \\
\hline Mean Max Age of Males & 44.1 & 40.3 & 41.7 & 38.7 & 32.7 \\
\hline Mean Max Education of Females & 2.9 & 2.4 & 2.1 & 2.6 & 4.0 \\
\hline Mean Max Education of Males & 4.4 & 3.7 & 3.3 & 6.0 & 5.5 \\
\hline Mean Household Size & 5.3 & 5.2 & 5.2 & 5.9 & 5.1 \\
\hline Observations $^{1}$ & 1711 & 912 & 786 & 57 & 145 \\
\hline \multicolumn{6}{|l|}{ Male Recipient } \\
\hline Percent Male Head & $86.2 \%$ & $95.3 \%$ & $97.3 \%$ & $93.5 \%$ & $97.2 \%$ \\
\hline Percent No Spouse Present & $16.7 \%$ & $7.4 \%$ & $3.8 \%$ & $8.8 \%$ & $8.9 \%$ \\
\hline Mean Pre-Transfer Income (1995 Taka) & 22,425 & 22,937 & 21,966 & 24,517 & 21,026 \\
\hline Mean Age of Head & 44.6 & 49.7 & 46.4 & 46.6 & 57.5 \\
\hline Mean Education of Head & 2.4 & 3.1 & 3.3 & 3.0 & 3.4 \\
\hline Mean Max Age of Females & 41.1 & 45.5 & 43.9 & 42.6 & 51.7 \\
\hline Mean Max Age of Males & 41.0 & 49.4 & 46.9 & 46.2 & 57.2 \\
\hline Mean Max Education of Females & 2.5 & 3.6 & 3.4 & 3.4 & 4.6 \\
\hline Mean Max Education of Males & 3.7 & 5.6 & 5.4 & 5.3 & 6.9 \\
\hline Mean Household Size & 5.0 & 6.0 & 5.9 & 6.2 & 6.3 \\
\hline Observations $^{1}$ & 2027 & 596 & 225 & 251 & 205 \\
\hline
\end{tabular}

Source: Authors' tabulations from the 1998/99 World Bank/BIDS survey of rural Bangladesh.

General Notes: Weights are used to adjust the choice-based sample to random sample proportions.

${ }^{1}$ Observations provide the unweighted number of households in each category.

${ }^{2}$ Non-recipient households include all households that did not contain a gift or loan recipient of the specified gender. 
TABLE 5 - Distribution of Gift and Loan Recipient and Non-Recipient Households by Income Quintile and Gender, 1998/99

\begin{tabular}{|c|c|c|c|c|c|c|}
\hline & \multirow{3}{*}{$\begin{array}{l}\text { Non-Recipient } \\
\text { Household }^{1}\end{array}$} & \multicolumn{5}{|c|}{ Household that received: } \\
\hline & & \multirow{2}{*}{$\begin{array}{c}\text { Any type } \\
\text { of gift or } \\
\text { loan }\end{array}$} & \multirow[b]{2}{*}{ Informal Gift } & \multirow[b]{2}{*}{ Informal Loan } & \multicolumn{2}{|c|}{ Formal } \\
\hline & & & & & Any Formal & Microcredit \\
\hline \multicolumn{7}{|c|}{ Male or Female Recipient } \\
\hline 1st Quintile & 19.4 & 21.4 & 32.7 & 19.3 & 18.1 & 17.8 \\
\hline 2nd Quintile & 21.1 & 18.6 & 24.1 & 14.0 & 18.4 & 18.8 \\
\hline 3rd Quintile & 21.9 & 17.7 & 17.0 & 16.5 & 17.8 & 18.0 \\
\hline 4th Quintile & 17.8 & 20.0 & 7.4 & 24.8 & 22.6 & 22.9 \\
\hline 5th Quintile & 20.0 & 22.4 & 19.0 & 25.5 & 23.1 & 22.6 \\
\hline \multicolumn{7}{|l|}{ Female Recipient } \\
\hline 1st Quintile & 20.0 & 21.3 & 45.3 & 21.9 & 16.5 & 16.3 \\
\hline 2nd Quintile & 20.3 & 18.7 & 21.7 & 17.0 & 19.1 & 18.9 \\
\hline 3rd Quintile & 21.0 & 17.0 & 10.1 & 10.4 & 18.4 & 18.7 \\
\hline 4th Quintile & 18.1 & 20.5 & 6.9 & 30.3 & 22.3 & 22.3 \\
\hline 5th Quintile & 20.6 & 22.4 & 16.0 & 20.4 & 23.7 & 23.8 \\
\hline \multicolumn{7}{|l|}{ Male Recipient } \\
\hline 1st Quintile & 20.1 & 21.1 & 24.0 & 19.1 & 23.1 & 26.1 \\
\hline 2nd Quintile & 20.5 & 17.9 & 25.8 & 12.9 & 15.1 & 17.5 \\
\hline 3rd Quintile & 20.1 & 19.1 & 21.8 & 18.4 & 15.1 & 13.4 \\
\hline 4th Quintile & 18.9 & 18.6 & 7.5 & 23.9 & 23.2 & 23.2 \\
\hline 5th Quintile & 20.5 & 23.3 & 20.9 & 25.7 & 23.5 & 19.8 \\
\hline
\end{tabular}

Source: Authors' tabulations from the 1998/99 World Bank/BIDS survey of rural Bangladesh.

General Notes: Weights are used to adjust the choice-based sample to random sample proportions. Household income quintile is determined using total pre-transfer household income in the past year. Distribution is determined by the percentage of households in each quintile receiving the specified gift or loan in the past year.

${ }^{1}$ Non-recipient households include all households which did not contain a gift or loan recipient of the specified gender.

A few additional patterns become evident when household income and transfer recipiency is broken down by gender (Tables 4 and 5). When females received informal gifts or loans, especially informal gifts, the household was more likely to be female-headed or lack a spouse. Women headed over half of all households where females received informal gifts and nearly half of those recipient households lacked a spouse. At the same time, nearly half (45 percent) of all households with female recipients of informal gifts were in the lowest income quintile. While households with male informal gift recipients were also slightly poorer than the average household, they do not appear to be as poor as the female recipient households. The data also show that households with female informal gift recipients were not older than the average household, however households with male recipients contained significantly older individuals than the average household.

Individual Characteristics: The characteristics of individual recipients of credit and transfers reiterate much of the information from the household characteristics-largely that recipients of informal gifts differ the most from other types of recipients. They are, on average, older, less likely to be married (though most are married), and more likely to be widowed. But the characteristics of individual recipients also add a more detailed picture about who was receiving gifts and loans in rural Bangladesh (Table 6). With the exception of formal credit (including microcredit), household heads received the majority of gifts and loans. 
TABLE 6 - Individual Characteristics of Gift and Loan Recipients by Gender, 1998/99

\begin{tabular}{|c|c|c|c|c|c|c|}
\hline & \multirow{3}{*}{$\begin{array}{l}\text { All Gifts and } \\
\text { Loans }\end{array}$} & \multirow{3}{*}{ Informal Gifts } & \multicolumn{4}{|c|}{ Type of Loan Received } \\
\hline & & & \multirow[b]{2}{*}{ All } & \multicolumn{2}{|c|}{ Formal } & \multirow[b]{2}{*}{ Informal } \\
\hline & & & & Any Formal & Microcredit & \\
\hline \multicolumn{7}{|l|}{ All Recipients } \\
\hline Mean Age & 39.5 & 48.6 & 37.1 & 35.9 & 35.0 & 40.9 \\
\hline Mean Education & 2.2 & 3.0 & 2.0 & 1.7 & 1.4 & 3.0 \\
\hline \multicolumn{7}{|c|}{ Household Relationship } \\
\hline Head & $43.0 \%$ & $64.9 \%$ & $37.7 \%$ & $24.1 \%$ & $17.5 \%$ & $75.8 \%$ \\
\hline Spouse & $47.9 \%$ & $24.2 \%$ & $53.8 \%$ & $69.0 \%$ & $75.6 \%$ & $11.9 \%$ \\
\hline Child & $4.3 \%$ & $4.4 \%$ & $4.2 \%$ & $2.7 \%$ & $2.2 \%$ & $7.9 \%$ \\
\hline Parent & $1.9 \%$ & $4.4 \%$ & $1.2 \%$ & $1.1 \%$ & $1.2 \%$ & $1.5 \%$ \\
\hline Other & $3.0 \%$ & $2.1 \%$ & $3.1 \%$ & $3.1 \%$ & $3.5 \%$ & $2.9 \%$ \\
\hline Percent Married & $86.3 \%$ & $72.4 \%$ & $89.1 \%$ & $89.9 \%$ & $89.4 \%$ & $87.5 \%$ \\
\hline Percent Widowed & $9.7 \%$ & $21.2 \%$ & $7.4 \%$ & $7.9 \%$ & $8.3 \%$ & $6.2 \%$ \\
\hline \multicolumn{7}{|l|}{ Female Recipients } \\
\hline Mean Age & 36.0 & 41.9 & 34.9 & 34.7 & 34.6 & 39.0 \\
\hline Mean Education & 1.5 & 2.4 & 1.3 & 1.3 & 1.2 & 1.7 \\
\hline \multicolumn{7}{|c|}{ Household Relationship } \\
\hline Head & $10.7 \%$ & $31.4 \%$ & $7.0 \%$ & $6.4 \%$ & $6.4 \%$ & $15.8 \%$ \\
\hline Spouse & $80.0 \%$ & $49.8 \%$ & $85.6 \%$ & $87.1 \%$ & $87.3 \%$ & $65.2 \%$ \\
\hline Child & $2.2 \%$ & $6.2 \%$ & $1.5 \%$ & $1.3 \%$ & $1.0 \%$ & $4.6 \%$ \\
\hline Parent & $3.1 \%$ & $9.0 \%$ & $2.0 \%$ & $1.4 \%$ & $1.4 \%$ & $8.8 \%$ \\
\hline Other & $4.1 \%$ & $3.7 \%$ & $3.9 \%$ & $3.8 \%$ & $3.9 \%$ & $5.5 \%$ \\
\hline Percent Married & $81.2 \%$ & $50.3 \%$ & $86.5 \%$ & $88.5 \%$ & $88.7 \%$ & $63.7 \%$ \\
\hline Percent Widowed & $15.7 \%$ & $42.0 \%$ & $11.7 \%$ & $9.9 \%$ & $9.6 \%$ & $33.5 \%$ \\
\hline \multicolumn{7}{|l|}{ Male Recipients } \\
\hline Mean Age & 44.5 & 54.8 & 40.6 & 40.7 & 37.3 & 41.3 \\
\hline Mean Education & 3.3 & 3.4 & 3.3 & 3.4 & 2.7 & 3.3 \\
\hline \multicolumn{7}{|c|}{ Household Relationship } \\
\hline Head & $90.5 \%$ & $96.2 \%$ & $88.9 \%$ & $91.0 \%$ & $87.6 \%$ & $88.4 \%$ \\
\hline Spouse & $0.6 \%$ & $0.2 \%$ & $0.9 \%$ & $1.0 \%$ & $1.6 \%$ & $0.7 \%$ \\
\hline Child & $7.4 \%$ & $2.7 \%$ & $8.7 \%$ & $7.7 \%$ & $10.1 \%$ & $8.6 \%$ \\
\hline Parent & $0.1 \%$ & $0.2 \%$ & $0.0 \%$ & $0.0 \%$ & $0.0 \%$ & $0.0 \%$ \\
\hline Other & $1.4 \%$ & $0.6 \%$ & $1.6 \%$ & $0.4 \%$ & $0.6 \%$ & $2.3 \%$ \\
\hline Percent Married & $93.7 \%$ & $93.0 \%$ & $93.4 \%$ & $95.1 \%$ & $93.9 \%$ & $92.5 \%$ \\
\hline Percent Widowed & $0.8 \%$ & $1.7 \%$ & $0.3 \%$ & $0.4 \%$ & $0.0 \%$ & $0.5 \%$ \\
\hline
\end{tabular}

Source: Authors' tabulations from the 1998/99 World Bank/BIDS survey of rural Bangladesh.

General Notes: Weights are used to adjust the choice-based sample to random sample proportions.

The household head received roughly 76 percent of informal loans and 65 percent of informal gifts. Formal credit is the exception because a large portion of formal credit (more specifically microcredit) is targeted towards women. As a result, the spouse of the household head received the majority of formal credit.

Table 6 shows several differences between the recipients of various types of gifts and loans as well as differences between male and female recipients. Male recipients of informal transfers are significantly older than other types of male recipients as well as female informal transfer recipients. Additionally, the data also show that male recipients of all types are more likely to be married than female recipients and less likely to be widowed. Finally, the table illustrates that male recipients tend to be more educated than female recipients, which is not 
surprising in rural Bangladesh. Furthermore, recipients of informal credit and transfers of both genders appear to be slightly more educated than recipients of formal credit.

\section{The Nature of Credit and Transfers in the Formal and Informal Sectors}

Sources of Informal Credit and Transfers: Relatives (as opposed to non-relatives) were the primary sources and recipients of informal credit and transfers in rural Bangladesh during 1998/99. Relatives accounted for 61 percent of the total value of informal loans received and were the only senders of informal gifts (Table 3 ). While slightly more households received loans from non-relative than relatives, the average size of loans from relatives was roughly three times the size of the average loan from non-relatives. The fact that informal transfers occurred only between relatives as opposed to non-relatives is similar to findings in previous studies.

The largest source of informal transfer money was remittances from relatives living abroad (Figure 2). Though more households received informal gifts from within Bangladesh, the average size of gifts received from abroad were roughly four times the size of gifts from urban areas and ten times the size of gifts from rural areas. Overall, remittances accounted for 71 percent of the total value of informal gifts received.

Households were more likely to receive gifts from close relatives (parents, spouses, and children) and more likely to receive loans from more distant relatives (i.e., in-laws and relatives such as aunt/uncles). ${ }^{10}$ Overall, households received only three percent of their informal relative loan value from parents and children while they received 87 percent of their informal gift value from parents, spouses, and children. Children alone accounted for roughly half of the value of all informal gifts received. Households received about the same amount of gifts as loans from siblings. Interestingly, money received from the recipient's parents was more likely to be a gift while money received from the parents of the recipient's spouse was more likely to be a loan.

Households received non-relative credit from a wide variety of sources, however neighbors were the single largest source of informal non-relative credit. Friends and neighbors combined for roughly forty percent of all informal non-relative credit. Meanwhile, roughly two percent of households received credit from moneylenders, accounting for 23 percent of all nonrelative informal credit and 9 percent of the informal credit received. Overall, households turned to relatives and close acquaintances (i.e., friends and neighbors) for over 75 percent of the total value of informal loans they received.

Recipients of informal transfers and credit from relatives were more likely to receive gifts than loans. Nearly three times as many households received gifts from relatives (14.6 percent) than loans (5.6 percent, Table 3). Interestingly, while households in this survey received substantially more money in gifts and loans from relatives, they actually sent slightly more money in loans than gifts to relatives (not shown). Though the differences in the number and size of gifts and loans sent to relatives are slight, they do provide further evidence of the fluid

\footnotetext{
${ }^{10}$ This pattern may still signal a fluid interpretation of transfers and loans. Households may assume that everything received from closer relatives are a gift and everything received from a distant relative is a loan.
} 
interpretation of gifts and loans with households more likely to consider money received informally as a gift and money sent informally as a loan.

Types of Informal Credit and Transfers: Informal sector gifts and loans are predominantly sent in the form of cash (as opposed to in-kind) in rural Bangladesh. Cash gifts and loans accounted for over 95 percent of both informal sector transfers sent and received in the past year (Figure 3). Food and other gifts comprised only about five percent of gifts received. ${ }^{11}$ Few households appear to receive food and other gifts, and the size of those gifts is drastically smaller than the cash gifts and loans.

Figure 3. Types of Informal Gifts and Loans, 1998/99

Percentage of Total Household Informal Gifts and Loans Sent and Received
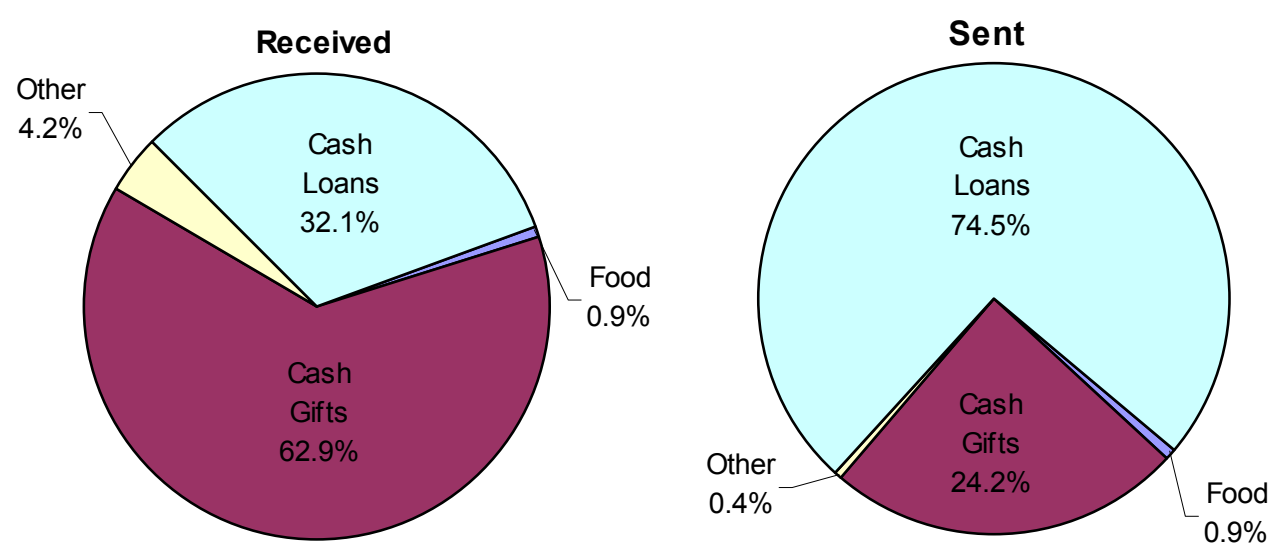

Source: Authors' w eighted tabulation from the 1998/99 World Bank/BIDS survey of rural Bangladesh

Sources of Formal Credit: Microcredit was the primary source of formal credit in rural Bangladesh during 1998 and 1999. According to the survey data, microcredit comprised 83 percent of formal lending in the past year (Table 3). The Grameen Bank accounted for nearly half (48 percent) of all formal loans and over half (58 percent) of all microcredit loans. More than a quarter of all households received at least one microcredit loan in the past year, and eighteen percent of households received a loan from at least one of the three main microcredit institutions - BRAC, BRDB, and the Grameen Bank. The Grameen Bank alone provided credit to twelve percent of all households. Only four percent of households received a loan from either the government or another non-government institution, however the average loan size was slightly larger from those institutions $(9,502 \mathrm{Tk}$.) than from microcredit banks $(6,700 \mathrm{Tk}$.).

Perhaps it shouldn't be surprising to see that microcredit is the primary source of formal credit in rural Bangladesh. As noted, Bangladesh has the largest operation of microcredit programs in the world, with about 12.4 million active borrowers and over 629 NGOs engaged in microcredit (World Bank 2003, 21).

\footnotetext{
${ }^{11}$ It is possible that food and other gifts may be slightly underrepresented in the survey since cash gifts and loans may be easier to account for than food or other gifts, especially since the size of these gifts may be quite small. Additionally, there is likely greater measurement error with food and other gifts as respondents may be more likely to forget these transfers.
} 
TABLE 7 - Size of Gifts and Loans Received Relative to Total Household Income, 1998/99

\begin{tabular}{lcccccc}
\hline \hline & & & \multicolumn{3}{c}{ Type of Loan Received } \\
\cline { 3 - 6 } & & & & \multicolumn{2}{c}{ Formal } \\
\cline { 3 - 6 } & All Gifts and Loans & Informal Gift & All & Any Formal & Microcredit & Informal \\
\hline 1st Quintile & $265.3 \%$ & $77.0 \%$ & $329.6 \%$ & $364.5 \%$ & $397.2 \%$ & $177.9 \%$ \\
2nd Quintile & $62.4 \%$ & $47.7 \%$ & $58.2 \%$ & $59.7 \%$ & $60.1 \%$ & $38.8 \%$ \\
3rd Quintile & $41.1 \%$ & $32.4 \%$ & $39.5 \%$ & $34.7 \%$ & $33.1 \%$ & $42.4 \%$ \\
4th Quintile & $28.5 \%$ & $27.4 \%$ & $26.7 \%$ & $26.6 \%$ & $25.2 \%$ & $21.7 \%$ \\
5th Quintile & $27.8 \%$ & $22.1 \%$ & $26.4 \%$ & $20.7 \%$ & $17.2 \%$ & $30.8 \%$ \\
All & $86.2 \%$ & $48.3 \%$ & $88.3 \%$ & $92.5 \%$ & $95.8 \%$ & $57.6 \%$ \\
\hline
\end{tabular}

Source: Authors' tabulations from the 1998/99 World Bank/BIDS survey of rural Bangladesh.

General Notes: Weights are used to adjust the choice-based sample to random sample proportions. The relative size of gifts gifts and loans is based on total post-transfer household income in the past year. Gifts are counted as income while loans are not.

Size of Transfers and Credit Relative to Household Income: Credit and transfers received by households were large in comparison with total household income (Table 7). ${ }^{12}$ Informal transfers received were nearly half of total household income and accounted for a far greater percentage for households in the lowest income quintiles $(77$ percent for households in the bottom quintile). The data appear to show that informal transfers may be more important to rural Bangladesh recipients than recipients of other countries. For example, Cox and Jimenez (1995) found that private transfers accounted for roughly 15 percent of total household income for rural recipient households in the Philippines and Cox (2002) found that they amounted to approximately 25 percent of household income for recipients in Vietnam.

The size of the informal transfers relative to income may be slightly higher in 1998 than other years due to the flooding that occurred in Bangladesh in 1998. Nonetheless many households rely heavily on informal transfers, especially remittances from abroad. One study estimated that 3 million workers of Bangladeshi origin were working abroad, and those workers sent remittances to roughly four percent of all Bangladeshi households (World Bank 2002). Of those households receiving remittances, roughly half used them as their primary source of income. Our data show roughly five percent of rural households received remittances that averaged 40,000 Taka in size. Thus, it appears that for those relatively few households (14.6 percent) who received informal transfers, the value of the transfers made up a substantial portion of household income.

Not surprisingly, credit of all forms was larger relative to total household income than informal transfers. Not only is the value of credit received not included in total household income, but loans may often be used for more than a single year. While informal transfers are generally used for consumption in a given year, credit may be used over the course of several years to generate additional income. Nevertheless, the important point from this analysis is that the loans received by rural households in Bangladesh were not inconsequential. For example, the average loan received from a microcredit organization was nearly equivalent in value to the entire yearly household income for the average recipient household. For those households in the

\footnotetext{
12 The value of transfers received is included as part of household income while the value of credit received is not, thus allowing for credit to make up more than 100 percent of household income.
} 
lowest income quintile, average microcredit loans received were valued at nearly four times the annual household income.

Overall, the value of gifts and loans received by households in rural Bangladesh were equivalent to approximately 86 percent of total income, on average, for recipient households. Thus we have seen that nearly half of all households received credit and/or transfers in rural Bangladesh, and the value of those transactions was quite large relative to household income.

\section{The Role of Formal and Informal Sectors by Gender}

In rural Bangladesh, men receive more money through transfers and credit than women. The average household received about 3,700 Taka in formal and informal gifts and loans to men while women, on average, only received roughly 2,900 Taka (not shown). This difference is due to the larger loan sizes received by men, especially informal loans (Table 8). There are actually fewer households where females did not receive any gift or loan (70 percent) than households where males did not receive a gift or loan (76 percent, not shown).

Relative Importance of Formal and Informal Sectors by Gender: Surprisingly, males rely almost entirely on informal credit and transfers while females are relatively split between their reliance on the formal and informal financial sectors. Males received only 16 percent of their credit and transfers from formal sources (Table 8). ${ }^{13}$ Females, on the other hand, received over half (52 percent) of their credit and transfers from the formal sector.

Within the informal sector, women rely almost exclusively on gifts (as opposed to loans). Nearly three times as many households had women receive informal gifts as received informal loans, and the average gift size was roughly three times the average loan size (Table 8). Overall, informal loans accounted for only five percent of total transfers and credit for women while informal gifts accounted for 43 percent of the total.

Unlike women who rely mostly on gifts in the informal sector, men depend on both informal gifts and loans. In rural Bangladesh, more households had males who received informal loans (11 percent) than gifts (9 percent). However, because the average gift size was roughly 1.7 times greater than the average loan size, the total value of informal gifts received by males was still slightly larger than the total value of informal loans received. In comparison with women, though, informal loans are much more important to men as they account for nearly half of the male informal sector (42 percent) and only ten percent of the female informal sector.

\footnotetext{
${ }^{13}$ Again, these numbers underestimate the formal sector as formal transfers are not included in the survey.
} 
TABLE 8 - Sources of Gifts and Loans Received by Gender, 1998/99

\begin{tabular}{|c|c|c|c|c|c|c|c|c|c|c|}
\hline & \multicolumn{5}{|c|}{ Female } & \multicolumn{5}{|c|}{ Male } \\
\hline & $\begin{array}{c}\% \mathrm{HH} \\
\text { Received } \\
(1)\end{array}$ & $\begin{array}{c}\text { Mean } \\
\text { Amount } \\
\text { Received }^{1} \\
(2) \\
\end{array}$ & $\begin{array}{c}\% \text { of Total Gifts } \\
\text { and Loans in } \\
\text { Category }^{2} \\
(3)\end{array}$ & $\begin{array}{c}\% \text { of Total Gifts } \\
\text { and Loans } \\
\text { Received }{ }^{2} \\
(4) \\
\end{array}$ & $\begin{array}{c}\mathrm{n}^{3} \\
(5) \\
\end{array}$ & $\begin{array}{c}\% \mathrm{HH} \\
\text { Received } \\
(6)\end{array}$ & $\begin{array}{l}\text { Mean Amount } \\
\text { Received }^{1} \\
(7)\end{array}$ & $\begin{array}{c}\% \text { of Total Gifts } \\
\text { and Loans in } \\
\text { Category }^{2} \\
(8)\end{array}$ & $\begin{array}{c}\% \text { of Total Gifts } \\
\text { and Loans } \\
\text { Received }^{2} \\
(9) \\
\end{array}$ & $\begin{array}{c}\mathrm{n}^{3} \\
(10)\end{array}$ \\
\hline Informal Transfers & 5.7 & 21,603 & 100.0 & 42.5 & 145 & 9.1 & 19,975 & 100.0 & 48.9 & 205 \\
\hline Relative Transfers & 5.7 & 21,603 & 100.0 & 42.5 & 145 & 9.1 & 19,975 & 100.0 & 48.9 & 205 \\
\hline Spouse & 2.6 & 31,905 & 66.3 & 28.1 & 63 & 0.1 & 30,207 & 1.7 & 0.8 & 4 \\
\hline Child & 2.0 & 11,951 & 19.6 & 8.3 & 49 & 5.6 & 21,236 & 65.5 & 32.0 & 128 \\
\hline Parent & 0.4 & 24,941 & 8.9 & 3.8 & 13 & 0.7 & 21,699 & 8.6 & 4.2 & 16 \\
\hline Sibling & 0.3 & 4,786 & 1.3 & 0.5 & 11 & 1.3 & 18,526 & 13.7 & 6.7 & 30 \\
\hline In-law & 0.1 & 2,735 & 0.1 & 0.1 & 2 & 0.8 & 12,051 & 5.5 & 2.7 & 17 \\
\hline Other & 0.1 & 3,590 & 0.4 & 0.2 & 3 & 0.3 & 21,802 & 3.8 & 1.9 & 10 \\
\hline Informal Loans & 2.2 & 6,907 & 100.0 & 5.2 & 57 & 10.9 & 11,812 & 100.0 & 34.7 & 251 \\
\hline Relative Loans & 1.3 & 6,523 & 55.4 & 2.9 & 32 & 4.6 & 17,297 & 61.3 & 21.2 & 102 \\
\hline Parent & 0.0 & 5,635 & 0.9 & 0.0 & 1 & 0.1 & 2,101 & 0.1 & 0.0 & 4 \\
\hline Child & 0.0 & 8,270 & 1.4 & 0.1 & 1 & 0.1 & 18,819 & 1.6 & 0.6 & 4 \\
\hline Sibling & 0.3 & 4,346 & 7.3 & 0.4 & 8 & 1.0 & 23,528 & 19.1 & 6.6 & 19 \\
\hline Mother/Father-in-law & 0.2 & 20,919 & 20.9 & 1.1 & 4 & 0.8 & 28,847 & 18.1 & 6.3 & 10 \\
\hline Other Relative & 0.9 & 4,276 & 24.9 & 1.3 & 20 & 3.4 & 8,509 & 22.4 & 7.8 & 74 \\
\hline Non-Relative Loans & 1.1 & 6,232 & 43.7 & 2.3 & 29 & 7.7 & 6,501 & 38.7 & 13.4 & 178 \\
\hline Friends & 0.1 & 4,034 & 1.4 & 0.1 & 2 & 1.4 & 4,571 & 4.9 & 1.7 & 35 \\
\hline Neighbors & 0.4 & 3,924 & 11.6 & 0.6 & 11 & 3.0 & 4,587 & 10.6 & 3.7 & 71 \\
\hline Moneylenders & 0.3 & 12,547 & 25.8 & 1.4 & 8 & 2.1 & 4,314 & 6.9 & 2.4 & 51 \\
\hline Other Non-Relatives & 0.3 & 2,949 & 4.9 & 0.3 & 8 & 2.2 & 9,025 & 15.6 & 5.4 & 50 \\
\hline Formal Loans & 23.6 & 6,428 & 100.0 & 52.3 & 786 & 7.2 & 8,473 & 100.0 & 16.4 & 225 \\
\hline All Microcredit & 23.2 & 6,405 & 98.0 & 51.2 & 776 & 3.9 & 7,102 & 45.7 & 7.5 & 144 \\
\hline Program Loans & 15.7 & 7,277 & 75.4 & 39.4 & 575 & 2.8 & 8,152 & 37.8 & 6.2 & 114 \\
\hline BRAC & 4.8 & 4,764 & 14.9 & 7.8 & 151 & 0.3 & 7,826 & 3.3 & 0.5 & 7 \\
\hline BRDB & 1.0 & 5,066 & 3.4 & 1.8 & 34 & 0.8 & 6,530 & 9.0 & 1.5 & 25 \\
\hline $\mathrm{GB}$ & 10.3 & 8,438 & 57.1 & 29.8 & 405 & 1.7 & 8,990 & 25.5 & 4.2 & 82 \\
\hline Other Microcredit & 8.3 & 4,159 & 22.6 & 11.8 & 223 & 1.1 & 4,388 & 7.9 & 1.3 & 30 \\
\hline Other Formal Loans & 0.5 & 6,013 & 2.2 & 1.1 & 14 & 3.3 & 10,084 & 54.0 & 8.9 & 82 \\
\hline Government & 0.1 & 3,855 & 0.4 & 0.2 & 4 & 1.7 & 8,259 & 23.0 & 3.8 & 45 \\
\hline Non-Government & 0.4 & 6,247 & 1.8 & 0.9 & 11 & 1.8 & 10,618 & 31.0 & 5.1 & 42 \\
\hline
\end{tabular}

Source: Authors' tabulations from the 1998/99 World Bank/BIDS survey of rural Bangladesh.

General Notes: Weights are used to adjust the choice-based sample to random sample proportions. Columns may not add up due to rounding. See text for category definitions.

${ }^{1}$ Mean provides the average cumulative amount (1995 Tk.) that a household received, for households with non-zero values. Average 1995 Tk./US $\$$ exchange rate is 40.278.

${ }^{2}$ Percentages are calculated based on the total value received (accounting for the percentage of households receiving and average amount received).

${ }^{3} \mathrm{n}$ provides the unweighted number of households who received the specified gift or loan. 
Informal Credit and Transfers by Gender: Informal gifts and loans flow primarily between men in rural Bangladesh. Over half of all informal gifts (57 percent) and loans ( 83 percent) received were from men to other men (Figure 4). The next largest portion of these transactions was from men to women, comprising roughly 40 percent of all informal gifts and 8 percent of loans (Figure 4). Women sent only about three percent of all informal gifts and nine percent of all informal loans received. Even the majority of gifts and loans sent from women went to men. Overall, nearly three times as many households had males (19 percent) who were active in the informal sector compared with females ( 7 percent, not shown). This resulted in males receiving nearly 60 percent of all informal gifts and 90 percent of all informal loans in rural Bangladesh during in 1998/99.

Figure 4. Share of Total Informal Gifts and Loans Received by Sex of Sender and Receiver Uncorrected vs. Relative Correction*
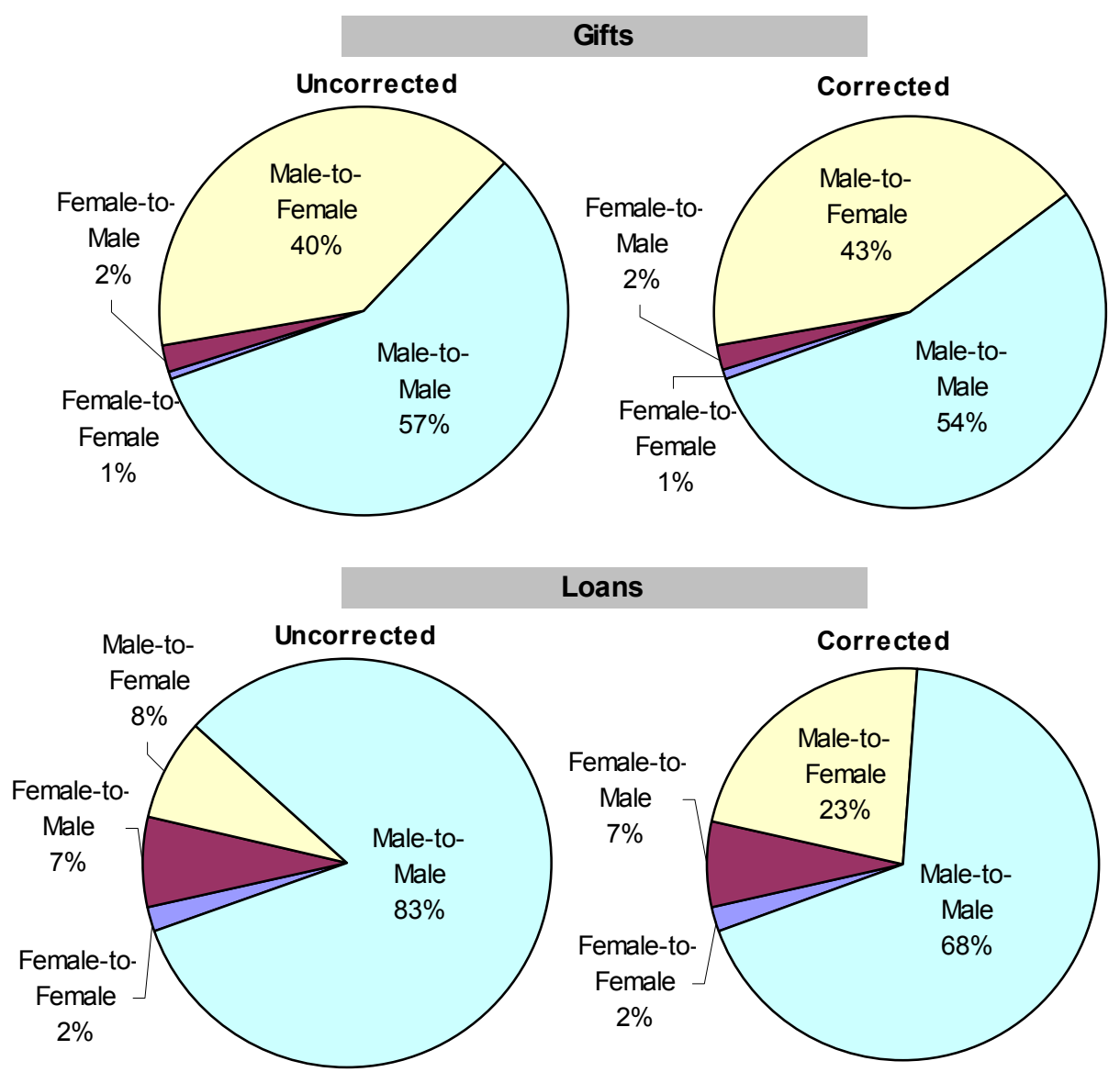

Source: Authors' w eighted tabulations from the 1998/99 World Bank/BIDS survey of rural Bangladesh *The correction adjusts the gender of recipients $w$ ho received loans and gifts from in-law $s$ to the opposite sex. Please refer to the text for further details. 


\begin{tabular}{|c|c|c|c|c|c|c|c|c|}
\hline & \multicolumn{4}{|c|}{ Received $^{1}$} & \multicolumn{4}{|c|}{ Received Corrected $^{2}$} \\
\hline & $\begin{array}{c}\% \mathrm{HH} \\
\text { Received }\end{array}$ & Mean $^{3}$ & $\begin{array}{l}\text { Standard } \\
\text { Error }\end{array}$ & $n^{4}$ & $\begin{array}{c}\% \mathrm{HH} \\
\text { Received }\end{array}$ & Mean $^{3}$ & $\begin{array}{c}\text { Standard } \\
\text { Error }\end{array}$ & $\mathrm{N}^{4}$ \\
\hline \multicolumn{9}{|l|}{ Relative Gifts } \\
\hline From Female to Female & $0.3 \%$ & 5,463 & 2488 & 14 & $0.4 \%$ & 5,123 & 2044 & 15 \\
\hline From Female to Male & $0.9 \%$ & 6,970 & 1693 & 20 & $0.9 \%$ & 7,288 & 1834 & 19 \\
\hline From Male to Female & $5.5 \%$ & 22,223 & 2819 & 136 & $5.9 \%$ & 22,142 & 2862 & 145 \\
\hline From Male to Male & $8.4 \%$ & 20,679 & 2660 & 192 & $8.0 \%$ & 20,782 & 2678 & 182 \\
\hline \multicolumn{9}{|l|}{ Relative Loans } \\
\hline From Female to Female & $0.3 \%$ & 3,852 & 1442 & 9 & $0.3 \%$ & 3,061 & 764 & 10 \\
\hline From Female to Male & $1.1 \%$ & 6,109 & 2283 & 26 & $1.1 \%$ & 6,189 & 2253 & 26 \\
\hline From Male to Female & $1.0 \%$ & 7,036 & 2593 & 23 & $1.6 \%$ & 17,434 & 7740 & 28 \\
\hline From Male to Male & $3.7 \%$ & 19,558 & 6398 & 80 & $3.3 \%$ & 15,473 & 4707 & 76 \\
\hline \multicolumn{9}{|l|}{ Non-Relative Loans } \\
\hline From Female to Female & $0.5 \%$ & 3,598 & 999 & 14 & $0.5 \%$ & 3,598 & 999 & 14 \\
\hline From Female to Male & $0.9 \%$ & 3,685 & 901 & 23 & $0.9 \%$ & 3,685 & 901 & 23 \\
\hline From Male to Female & $0.4 \%$ & 11,465 & 6843 & 8 & $0.4 \%$ & 11,465 & 6843 & 8 \\
\hline From Male to Male & $6.4 \%$ & 6,957 & 1331 & 153 & $6.4 \%$ & 6,957 & 1331 & 153 \\
\hline
\end{tabular}

Source: Authors' tabulations from the 1998/99 World Bank/BIDS survey of rural Bangladesh.

General Notes: Weights are used to adjust the choice-based sample to random sample proportions.

${ }^{1}$ The sex of the gift or loan source is missing in certain cases. Therefore the sum of the gifts and loans by gender will not add up to total informal gifts and loans.

${ }^{2}$ The correction adjusts the gender of recipients who received loans and gifts from in-laws to the opposite sex. Please refer to the text for further details.

${ }^{3}$ Mean provides the average cumulative amount (in 1995 Taka) that a household received, for households with non-zero values. Average 1995 Tk./U.S. \$ exchange rate is 40.278 .

${ }^{4} \mathrm{n}$ provides the unweighted number of households who received the specified loan or gift.

Though men still send and receive the majority of informal transfers, the gender differences are much larger for informal credit than for informal transfers, especially with respect to credit from nonrelatives. Approximately eight times as many households had men receive loans from non-relatives as had women receive loans from non-relatives (Table 9). Furthermore, the informal loans received by men were significantly larger, on average, than the informal loans received by women. The finding that informal transfers and credit flow primarily between men in Bangladesh is surprising because the limited evidence on the flow of informal transfers and credit from the literature suggests that they are more likely to flow to women (Cox and Jimenez 1992). Even limiting our analysis to informal transfers (as Cox and Jimenez did), the majority of informal transfers (gifts) received were from men to other men.

Within the informal sector, men and women looked to different sources for informal transfers (Table 8). ${ }^{14}$ The single largest source of informal transfers for women was their spouses, accounting for roughly two-thirds of all informal transfers. Men, on the other hand, received nearly two-thirds of their informal transfers from children and only two percent of their informal transfers from spouses. Children were the second largest source of informal transfers for women, sending approximately 28

\footnotetext{
${ }^{14}$ While there were significant gender differences in the sources of informal gifts, the differences are not as evident with respect to informal loans. However, this may be due to the exceptionally small number of females receiving informal loans. With only 57 total observations, it is difficult to make strong generalizations. The larger point with respect to informal loans is that women rarely receive them, no matter which source sends the loan.
} 
percent of the total value of informal gifts received by women. Additionally, siblings and in-laws were much more important sources of informal transfers for men than for women.

Combining the information on the senders of informal transfer with the individual characteristics of recipients, we can piece together a much clearer picture of who was receiving informal transfers in Bangladesh. It appears that a significant number of older men, almost all of whom were still married, received informal gifts mostly from children. Women informal transfer recipients were more likely to be split into two types: (1) older widows who received gifts from children and (2) younger wives who received informal transfers from spouses who were temporarily away from the household. The data show that children were much more likely to send transfers to their fathers if they were still alive than to their mothers, which is not surprising in the male-dominated society. Obviously not all recipients fit these categories, and many households received gifts from sources other than children and spouses; however these categories fit a large portion of the recipients of informal transfers.

Throughout our analysis, we use the gender of the sender and recipient as reported by households in the survey. However, households may not always report the true recipient of the gift or loan. Whether due to cultural, religious, or other issues, it may be that households report a male as the recipient, even if the transaction was directed to a female in the household. To investigate whether the gender results are sensitive to this reporting, we reclassify the gender of some recipients (senders) by their relationship to the sender (recipient). In general, recipients (senders) who received (sent) a gift or loan from (to) an in-law are recoded as the opposite sex for this sensitivity analysis. For example, a male who receives a transfer from a mother/father in-law would be reclassified as a female recipient. Similarly, a female who sends a loan to a brother/sister in-law would be reclassified as a male sender. In the end, this recoding did not have an enormous effect on the results. In total, out of roughly 1,200 observations of individuals sending and receiving informal gifts and loans, only 36 observations were reclassified from male to female and only 21 observations were reclassified from female to male.

Figure 4 displays the results from this correction. While males remain the primary recipients and sources of gifts and loans after the reclassification, there was a definite shift from male-to-male flows to male-to-female flows for both gifts and loans. The shift is much larger with respect to loans, however looking more closely at the data reveals that the shift was caused mostly by the movement of a few relatively large loans from men to women. Nevertheless, in-laws are clearly a more important source for informal gifts and loans for males than females, leading to the conclusion that women are somewhat more important to the informal sector than they would appear at first glance. Without the female spouse, these transactions never would have occurred.

Formal Credit by Gender: In rural Bangladesh, microcredit is effectively the only source of formal credit for women and is also an important source of formal credit for men. Microcredit accounted for an astounding 98 percent of formal loans to women (Table 8). Nearly six times as many households had women who received credit from a microcredit organization (23 percent) as households with male microcredit recipients (4 percent). Though microcredit is a less vital source of formal credit for males, it still accounted for nearly half of all formal loans to men in the past year. 
Average loan sizes from microcredit organizations appeared to be slightly larger for men than for women.

Government and non-government loans (e.g., Krishi Bank, BSCIC) to women were virtually non-existent. Average loan amounts to women from government and non-government sources were similar in size to loan amounts from microcredit programs, but so few women received government and non-government loans ( 0.1 percent and 0.4 percent, respectively) that loans from those institutions made up only two percent of all formal credit received by females in the past year (Table 8).

Men, on the other hand, rely on government and non-government loans as an important source of formal credit. Non-government loans accounted for nearly one-third (31 percent) of all formal loans to men while government loans comprised over one-fifth (23 percent) of all formal loans received by men (Table 8). Not only do more men than women receive loans from government and nongovernment sources, but the average size of those loans is nearly double for men. On the whole, however, relatively few households have males receiving credit from government (1.7 percent), nongovernment (1.7 percent), or microcredit (3.9 percent) institutions, and the informal financial sector remains a much more important source for credit and transfers than the formal sector for men.

\section{E. The Relationship Between the Formal and Informal Sectors}

It is surprising that roughly half of all households received no gifts or loans in the past year (Figure 5). This suggests that there is room for financial sector growth in Bangladesh, especially given that many of the poorest households are not receiving credit or transfers from either sector. Seventysix percent of households had no male who received any gift or loan. Women fared only slightly better than men. Seventy percent of households had no female who received a gifts or loan in the past year. Excluding microcredit loans, over 90 percent of households did not have any female receiving money from either formal or informal sources.

Households in rural Bangladesh rarely receive gifts and loans from both the formal and informal sectors. While 49 percent of households received some type of formal or informal credit or transfer in the past year, only six percent of households received a gift or loan from both sectors (Figure 5). Twenty-four percent received credit only from a formal institution, and 19 percent received a gift or loan only from an informal source. Thus, of all households that received a gift or loan in the past year, only 12 percent received it from both the formal and informal sectors. ${ }^{15}$

\footnotetext{
${ }^{15}$ This percentage does not match the six percent number in Figure 4 because it includes only the 49 percent of households that received a gift or loan in the past year.
} 
Figure 5. Household Gifts and Loans Received

Percentage of Households Receiving Gifts and Loans by Sector
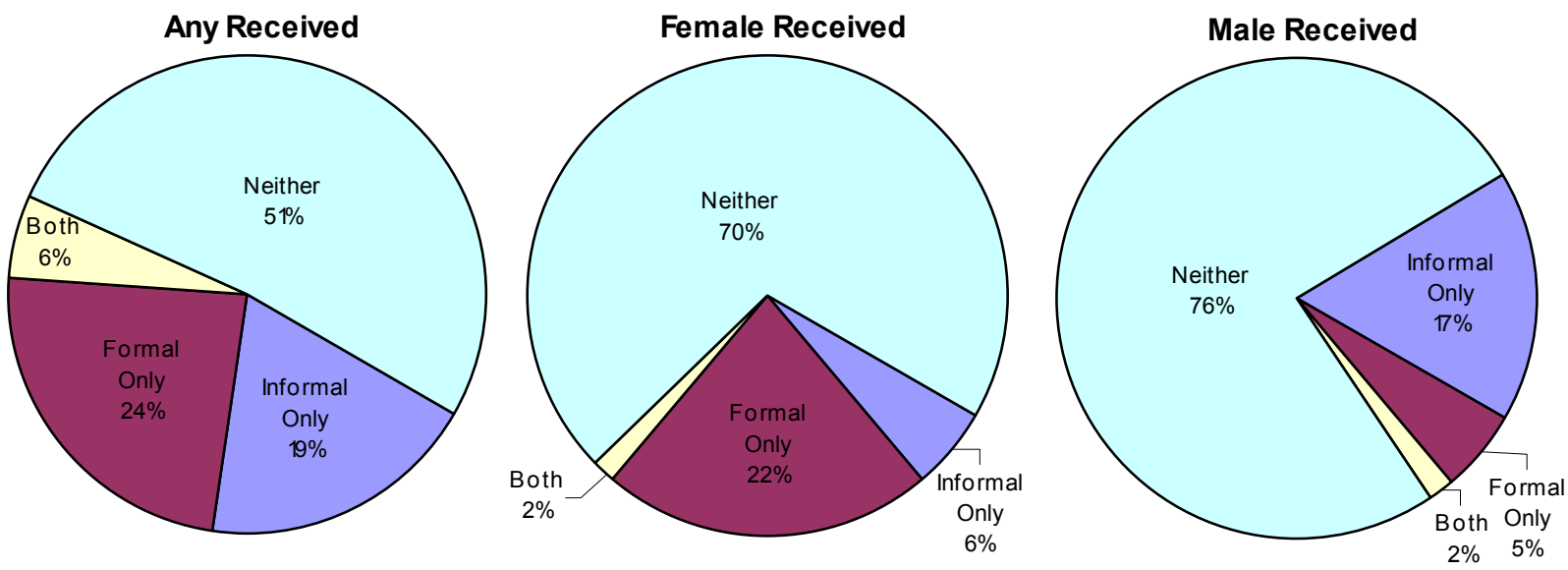

Source: Authors' w eighted tabulation from the 1998/99 World Bank/BIDS survey of rural Bangladesh

The use of both formal and informal credit and transfers is even rarer when looking at household behavior by gender. Only two percent of households had males and females receiving a gift or loan from both sectors (Figure 5). Instead, males rely almost entirely on the informal sector for credit and transfers while females rely on the formal sector and specifically microcredit institutions.

While the evidence clearly shows that individual households do not rely on both the formal and informal sectors for credit and transfers, the reason for this behavior is not as clear. It is possible that the formal sector is reaching a population of individuals who otherwise would not be able to access money from the informal sector. After all, our analysis of recipient households revealed that recipients of informal credit and transfer were wealthier, on average, than households that received formal loans. However, another possibility is that microcredit organizations and other formal sources may be crowding out the informal sector, replacing informal gifts and loans with formal loans.

To further investigate this issue, we take advantage of the panel nature of the survey and examine households that were included in both waves of the study. We descriptively examine the relationship between the formal and informal sectors. We examine whether formal sector finance is positively or negatively associated with informal sector finance, and whether this association varies for men and women. The associations identified do not necessarily imply a pattern of causation. 
TABLE 10 - Changes in the Use of the Formal and Informal Financial Sectors Between 1991/92 and 1998/99

\begin{tabular}{|c|c|c|c|c|c|}
\hline & \multirow[b]{2}{*}{ All } & \multicolumn{2}{|c|}{ Male } & \multicolumn{2}{|c|}{ Female } \\
\hline & & Household ${ }^{4}$ & Male $^{5}$ & Household $^{4}$ & Female $^{5}$ \\
\hline Formal Increased $^{1}$ & 537 & 115 & 115 & 464 & 464 \\
\hline Decreased Informal Sector & 77 & 18 & 14 & 66 & 27 \\
\hline No Change in Informal Sector & 375 & 73 & 79 & 331 & 407 \\
\hline Decreased Informal Sector & 33 & 19 & 17 & 16 & 10 \\
\hline No Change in Informal Sector & 181 & 110 & 114 & 107 & 130 \\
\hline Formal No Change ${ }^{3}$ & 843 & 1370 & 1370 & 1039 & 1039 \\
\hline Increased Informal Sector & 182 & 263 & 183 & 232 & 68 \\
\hline
\end{tabular}

Source: Authors' tabulations from the 1991/92 and 1998/99 World Bank/BIDS survey of rural Bangladesh.

General Notes: The table includes 1,652 households for which longitudinal data were available to examine changes in the use of the formal and informal sectors between 1991/92 and 1998/99. The informal sector includes both informal gifts and loans. All numbers are unweighted household counts.

${ }^{1}$ Formal increased includes all households that received more formal loans in 1998/99 than in 1991/92.

${ }^{2}$ Formal decreased includes all households that received less formal loans in 1998/99 than in 1991/92.

${ }^{3}$ Formal no change includes all households that received the same amount of formal loans in both waves.

${ }^{4}$ The household subcolumns display the household behavior in the informal sector given the particular change in the formal sector. For example, of the 115 households where male household members increased the cumulative value of formal loans they received between $1991 / 92$ and 1998/99, 24 households increased, 18 households decreased, and 73 households had no change in the cumulative value of informal gifts and loans received by (males and females in) the household between 1991/92 and 1998/99.

${ }^{5}$ The male and female subcolumns display the informal sector behavior of household members of the specified gender given the particular change in the formal sector. For example, of the 115 households where male household members increased the cumulative value of formal loans they received between 1991/92 and 1998/99, 22 households increased, 14 decreased, and 79 had no change in the cumulative value of informal gifts and loans received by males in the household between 1991/92 and 1998/99.

Of the 537 unweighted households that received more formal credit in 1998/99 than in 1991/92, 85 households (16 percent) also received more informal gifts and loans while 77 households (14 percent) received less informal gifts and loans. 375 households (70 percent) saw no change in money received from the informal sector - that is they received no finance from the informal sector in either wave (Table 10). ${ }^{16}$

The majority of households that received less formal credit in 1998/99 than in 1991/92 also received the same amount of money from the informal sector in both waves (67 percent, Table 11). Only 58 households (21 percent) received more money from the informal sector while 33 households (12 percent) received less money from the informal sector (Table 10). This pattern continues for households that had no change (zero in both waves) in the amount of formal credit in 1991/92 and 1998/99. These unweighted numbers suggest that formal credit may not substitute for informal credit and transfers in rural Bangladesh. No matter whether households received more, less, or the same amount of formal credit, the vast majority saw no change in money received from the informal sector, and a slightly larger percentage of households received more money from the informal sector than

\footnotetext{
${ }^{16}$ All households that saw no change in the amount of informal gifts and loans between 1991/92 and 1998/99 received no money in either wave of the survey from the informal sector. This is also the case for households that had no change in the amount of formal credit received.
} 
TABLE 11 - Correlation Coefficients Between the Change in the Use of the Formal and Informal Financial Sectors Between 1991/92 and 1998/99

\begin{tabular}{lccc}
\hline \hline & \multicolumn{3}{c}{ Change in Formal Loans } \\
\cline { 2 - 4 } Change in Informal Gifts and Loans & All & Male & Female \\
& 0.019 & 0.016 & 0.031 \\
Change in Informal Loans & $(0.44)$ & $(0.52)$ & $(0.21)$ \\
& & & \\
\end{tabular}

Source: Authors' tabulations from the 1991/92 and 1998/99 World Bank/BIDS survey of rural Bangladesh.

General Notes: The table includes 1,652 households for which longitudinal data were available to examine changes in the use of the formal and informal sectors between 1991/92 and 1998/99. P-values are in parentheses below the correlation coefficients. Correlation coefficients are weighted to adjust the choice-based sample to random sample proportions. Columns display changes in household behavior of the specified gender. For example, the male column displays the correlation coefficient between the change in the cumulative value of male informal gifts and loans between (or male informal loans only) and the change in the cumulative value of male formal loans.

received less money. We find similar results when credit and transfers are broken down by gender (Table 10) and when the relationship between formal credit and informal credit (i.e., excluding informal gifts from the analysis) is examined (not shown). The descriptive evidence appears to show that formal credit is mostly reaching households who otherwise would not have access to the informal sector or who choose not to move from the corner of no informal sector use.

The correlation coefficients between the change in money received from formal loans and from informal gifts and loans further support that the formal and informal sectors are not acting as substitutes. If the formal and informal sectors were linear substitutes, we would expect statistically significant negative correlation coefficients. However, Table 11 shows that none of the correlation coefficients are close to statistical significance, and few are even negative. Overall, none of the bivariate evidence suggests that households are substituting formal credit for the informal sector in rural Bangladesh. Instead, households with limited access to informal gifts and loans appear to receive the majority of formal credit.

\section{F. Changes in the Financial Sectors Between $1991 / 92$ and 1998/99}

During the seven years between the 1991/92 and the 1998/99 surveys, there was significant growth in both the formal and informal financial sectors in rural Bangladesh. Additional households gained access to money through credit and transfers, and the size of those transactions increased considerably. Beyond the growth in the receipt of transfers and credit, substantial shifts occurred in the sources of those formal and informal gifts and loans with large differences between males and females.

These changes occurred in the context of substantial economic growth, a large increase in microcredit programs, and a massive flood between the time periods. The gross domestic product of Bangladesh increased 52 percent between 1990 and 1999 (World Bank 2001), while rural poverty dropped roughly eight percentage points (World Bank 2002). The microcredit sector moved from being dominated by three major programs to over 629 NGOs engaged in microcredit. The massive 1998 flood led the government to increase formal transfers by 80 percent (World Bank 2002, 67) and 
exposed the vulnerability of microcredit programs to natural disasters. Many microcredit programs could not maintain their high loan recovery rates as borrowers suffered asset and income losses. With government help, many programs allowed borrowers to suspend loan repayments during the flood and allowed borrowers to take out new loans (World Bank 2003, 21).

Between 1991/92 and 1998/99, the average amount of formal loans and informal gifts and loans received increased substantially (Figure 6). ${ }^{17}$ Overall, the formal and informal sectors each increased by roughly two and a half times, leaving the informal sector larger than the formal sector throughout the 1990's in rural Bangladesh (68 percent versus 32 percent in both waves, not shown). ${ }^{18}$ However, the expansions in the two sectors were markedly different as the growth in the informal sector can be attributed almost entirely to increases in loan sizes while the formal sector growth was predominantly spurred by an expansion in the number of households receiving loans. In the formal sector, nearly twice as many households received formal loans in 1998/99 as in 1991/92 (Table 12). In the formal sector, formal transfers, primarily in the form of food for work, education, or training, grew 80 percent from FY 1992 to FY 1999. This increase was in response to heavy floods in 1998 (World Bank 2002, 67). Meanwhile, the informal sector, the percentage of households receiving informal gifts and loans remained steady, however the average size of those transactions more than doubled in the seven-year time span.

Figure 6. Informal and Formal Sectors by Survey Wave

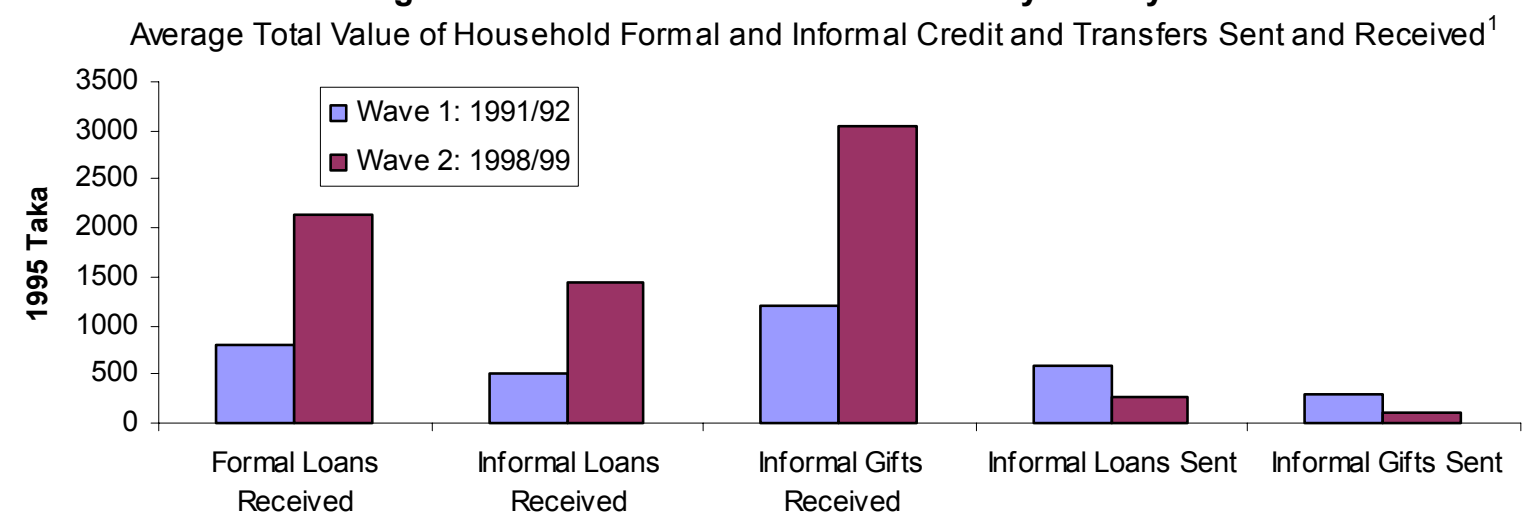

Source: Authors' w eighted tabulations from the 1991/92 and 1998/99 World Bank/BIDS survey of rural Bangladesh

${ }_{1}^{1}$ Average values are for both recipient and non-recipient households.

\footnotetext{
${ }^{17}$ In this analysis, we include data from all households in both waves keeping households that were in the first wave and not the second wave and vice versa. The average gift and loan values vary slightly when using only households that were included in both waves, however the results are qualitatively identical.

${ }^{18}$ As noted in Section A, a rough approximation of the formal sector estimates that including formal transfers in the formal sector measure revises the relative sizes of the informal and formal sector to 61 percent versus 39 percent.
} 
TABLE 12 - Sources of Gifts and Loans Received by Survey Wave

\begin{tabular}{|c|c|c|c|c|c|c|c|c|c|c|}
\hline & \multicolumn{5}{|c|}{ Wave 1: 1991/92 } & \multicolumn{5}{|c|}{ Wave 2: 1998/99 } \\
\hline & \multirow[b]{2}{*}{$\begin{array}{c}\% \mathrm{HH} \\
\text { Received } \\
(1)\end{array}$} & \multicolumn{2}{|c|}{ Amount Received } & \multirow[b]{2}{*}{$\begin{array}{c}\% \text { of Total } \\
\text { Gifts and } \\
\text { Loans in } \\
\text { Category } \\
\text { (4) }\end{array}$} & \multirow[b]{2}{*}{$\begin{array}{c}\% \text { of Total Gifts } \\
\text { and Loans } \\
\text { Received }{ }^{2} \\
(5)\end{array}$} & \multirow[b]{2}{*}{$\begin{array}{c}\% \mathrm{HH} \\
\text { Received } \\
(6)\end{array}$} & \multicolumn{2}{|c|}{ Amount Received } & \multirow[b]{2}{*}{$\begin{array}{l}\% \text { of Total Gifts } \\
\text { and Loans in } \\
\text { Category } \\
\text { (9) }\end{array}$} & \multirow[b]{2}{*}{$\begin{array}{c}\% \text { of Total Gifts } \\
\text { and Loans } \\
\text { Received }^{2} \\
(10)\end{array}$} \\
\hline & & $\begin{array}{c}\text { Mean }^{1} \\
(2)\end{array}$ & $\begin{array}{l}\text { Standard } \\
\text { Error } \\
\text { (3) }\end{array}$ & & & & $\begin{array}{c}\text { Mean }^{1} \\
(7)\end{array}$ & $\begin{array}{l}\text { Standard } \\
\text { Error } \\
\text { (8) }\end{array}$ & & \\
\hline Informal Gifts & 14.4 & 8,461 & 1519 & 100.0 & 47.8 & 14.6 & 20,879 & 1878 & 100.0 & 46.1 \\
\hline Relative Transfers & 14.4 & 8,461 & 1519 & 100.0 & 47.8 & 14.6 & 20,879 & 1878 & 100.0 & 46.1 \\
\hline Informal Loans & 11.8 & 4,356 & 394 & 100.0 & 20.3 & 12.7 & 11,339 & 2335 & 100.0 & 21.8 \\
\hline Relative Loans & 5.8 & 4,062 & 531 & 45.4 & 9.2 & 5.6 & 15,560 & 4455 & 60.5 & 13.2 \\
\hline Non-Relative Loans & 7.1 & 3,961 & 336 & 54.6 & 11.1 & 8.6 & 6,563 & 1065 & 39.2 & 8.5 \\
\hline Formal Loans & 15.7 & 5,178 & 404 & 100.0 & 32.0 & 29.3 & 7,254 & 298 & 100.0 & 32.1 \\
\hline All Microcredit & 13.1 & 4,989 & 145 & 80.2 & 25.6 & 26.4 & 6,700 & 199 & 83.1 & 26.7 \\
\hline Program Loans & 12.6 & 5,069 & 142 & 78.5 & 25.1 & 18.3 & 7,521 & 250 & 64.7 & 20.8 \\
\hline BRAC & 3.9 & 4,209 & 219 & 20.2 & 6.4 & 5.0 & 4,920 & 293 & 11.6 & 3.7 \\
\hline BRDB & 3.8 & 5,014 & 275 & 23.4 & 7.5 & 1.7 & 6,209 & 714 & 5.0 & 1.6 \\
\hline $\mathrm{GB}$ & 4.9 & 5,794 & 222 & 34.9 & 11.2 & 12.0 & 8,508 & 323 & 48.1 & 15.5 \\
\hline Other Microcredit & 0.5 & 2,738 & 661 & 1.7 & 0.6 & 9.1 & 4,300 & 251 & 18.4 & 5.9 \\
\hline Other Formal Loans & 2.7 & 5,986 & 2255 & 19.8 & 6.3 & 3.8 & 9,502 & 1728 & 17.0 & 5.5 \\
\hline Government & 1.2 & 4,452 & 460 & 6.8 & 2.2 & 1.8 & 7,904 & 740 & 6.9 & 2.2 \\
\hline Non-Government & 1.4 & 7,295 & 4115 & 13.0 & 4.2 & 2.2 & 9,764 & 2593 & 10.2 & 3.3 \\
\hline
\end{tabular}

Source: Authors' tabulations from the 1991/92 and 1998/99 World Bank/BIDS survey of rural Bangladesh.

General Notes: Weights are used to adjust the choice-based sample to random sample proportions. Columns may not add up due to rounding. Please see text for category definitions. The sample contains 1769 households in the 1st wave and 2623 households in the 2nd wave.

${ }^{1}$ Mean provides the average cumulative amount (1995 Tk.) that a household received, for households with non-zero values. Average 1995 Tk./US \$ exchange rate is 40.278.

${ }^{2}$ Percentages are calculated based on the total value received (accounting for the percentage of households receiving and average amount received). 
While the total value of informal gifts and loans received grew immensely, the average amount of informal gifts and loans sent decreased by more than half between 1991/92 and 1998/99 (Figure 6). Almost all of this decrease was due to the decreased percentage of households sending in the informal sector, however the average size of gifts and loans sent also decreased. Overall, a substantial portion of the decrease in sending, as well as some of the increase in receiving, can be explained by the flooding that occurred during the second wave of the survey. It is not surprising that households would receive more aid in a time of need and send less.

Loans from virtually all sources of formal credit increased between 1991/92 and 1998/99 (Table 12). The majority of the formal credit increase came from microcredit organizations. Twice as many households received a loan from a microcredit organization in 1998/99 as received one in 1991/92 (26 percent versus 13 percent, Table 12). A significant portion of this increase came from microcredit institutions outside of the three major programs, documenting the substantial rise of microcredit organizations in rural Bangladesh. Other microcredit organizations reached less than one percent of households in 1991/92, however by 1998/99, they reached nine percent of households. There was also a substantial increase in the size of two of the three main microcredit programs during the 1990's. In fact, the Grameen Bank doubled the number of households it lent money to (12 percent versus 5 percent) and increased the average loan size by nearly 60 percent $(8,508 \mathrm{Tk}$. versus $5,794 \mathrm{Tk})$.

The rise in microcredit lending was nearly matched by increases in the number and size of government and non-government loans. While more households received loans from these organizations in 1998/99, they still only reached four percent of households. However, the average loan size from these institutions did increase nearly 60 percent in the 1990's (Table 12). Overall, government and non-government loans grew at a slightly slower pace than microcredit loans, leading to a small increase in microcredit's share of formal lending in rural Bangladesh and maintaining its position as the dominant source of formal credit (Table 12).

Between 1991/92 and 1998/99, there was a shift in the financial sectors that men and women relied upon for transfers and credit in rural Bangladesh. Men turned more to the informal sector while women looked to the formal sector for transfer and credit funds. For men, the informal sector's share of gifts and loans increased from to 76 percent to 84 percent over the seven years (Table 13). This increase in the informal sector came mostly in the form of loans, however informal gifts also increased during that time span. Women, on the other hand, relied more heavily on the formal sector, which grew from 45 percent of all gifts and loans to 52 percent and became the main source of gift and loan money for women. Most of this increase in the formal sector came from the sharp jump in the percentage of households with women receiving formal loans ( 9 percent to 24 percent, Table 13), however the average formal loan increased in size as well. The expansion of the formal sector share of female gifts and loans was matched by an equal decline in informal gifts received by women with the informal loan share remaining stable. 
TABLE 13 - Sources of Gifts and Loans Received by Gender and Survey Wave

\begin{tabular}{|c|c|c|c|c|c|c|c|c|c|c|}
\hline & \multicolumn{5}{|c|}{ Wave 1: 1991/92 } & \multicolumn{5}{|c|}{ Wave 2: 1998/99 } \\
\hline & \multirow[b]{2}{*}{$\begin{array}{c}\% \mathrm{HH} \\
\text { Received } \\
(1)\end{array}$} & \multicolumn{2}{|c|}{ Amount Received } & \multirow[b]{2}{*}{$\begin{array}{c}\% \text { of Total Gifts } \\
\text { and Loans in } \\
\text { Category }^{2} \\
(4)\end{array}$} & \multirow[b]{2}{*}{$\begin{array}{c}\% \text { of Total Gifts } \\
\text { and Loans } \\
\text { Received }{ }^{2} \\
(5)\end{array}$} & \multirow[b]{2}{*}{$\begin{array}{c}\% \mathrm{HH} \\
\text { Received } \\
(6)\end{array}$} & \multicolumn{2}{|c|}{ Amount Received } & \multirow[b]{2}{*}{$\begin{array}{c}\% \text { of Total Gifts } \\
\text { and Loans in } \\
\text { Category }{ }^{2} \\
(9)\end{array}$} & \multirow[b]{2}{*}{$\begin{array}{c}\% \text { of Total Gifts } \\
\text { and Loans } \\
\text { Received }{ }^{2} \\
(10)\end{array}$} \\
\hline & & $\begin{array}{c}\text { Mean }^{1} \\
(2)\end{array}$ & $\begin{array}{c}\text { Standard } \\
\text { Error } \\
(3)\end{array}$ & & & & $\begin{array}{c}\text { Mean }^{1} \\
(7)\end{array}$ & $\begin{array}{c}\text { Standard } \\
\text { Error } \\
(8)\end{array}$ & & \\
\hline \multicolumn{11}{|l|}{ Female } \\
\hline Informal Gifts & 8.1 & 6,074 & 1259 & 100.0 & 50.6 & 5.7 & 21,603 & 2708 & 100.0 & 42.5 \\
\hline Informal Loans & 1.2 & 4,069 & 1193 & 100.0 & 4.9 & 2.2 & 6,907 & 1840 & 100.0 & 5.2 \\
\hline Relative Loans & 0.5 & 3,822 & 2207 & 39.9 & 2.0 & 1.3 & 6,523 & 2086 & 55.4 & 2.9 \\
\hline Non-Relative Loans & 0.7 & 4,072 & 805 & 60.1 & 3.0 & 1.1 & 6,232 & 2871 & 43.7 & 2.3 \\
\hline Formal Loans & 9.3 & 4,642 & 149 & 100.0 & 44.5 & 23.6 & 6,428 & 208 & 100.0 & 52.3 \\
\hline All Microcredit & 9.3 & 4,642 & 149 & 100.0 & 44.5 & 23.2 & 6,405 & 208 & 98.0 & 51.2 \\
\hline Program Loans & 9.1 & 4,710 & 144 & 99.1 & 44.1 & 15.7 & 7,277 & 268 & 75.4 & 39.4 \\
\hline BRAC & 3.4 & 3,981 & 223 & 31.3 & 13.9 & 4.8 & 4,764 & 275 & 14.9 & 7.8 \\
\hline $\mathrm{BRDB}$ & 1.9 & 4,191 & 239 & 18.0 & 8.0 & 1.0 & 5,066 & 314 & 3.4 & 1.8 \\
\hline GB & 3.8 & 5,604 & 227 & 49.8 & 22.1 & 10.3 & 8,438 & 356 & 57.1 & 29.8 \\
\hline Other Microcredit & 0.2 & 1,793 & 406 & 0.9 & 0.4 & 8.3 & 4,159 & 241 & 22.6 & 11.8 \\
\hline Other Formal Loans & 0.0 & 0 & 0 & 0.0 & 0.0 & 0.5 & 6,013 & 1547 & 2.2 & 1.1 \\
\hline Government & 0.0 & 0 & 0 & 0.0 & 0.0 & 0.1 & 3,855 & 174 & 0.4 & 0.2 \\
\hline Non-Government & 0.0 & 0 & 0 & 0.0 & 0.0 & 0.4 & 6,247 & 1913 & 1.8 & 0.9 \\
\hline \multicolumn{11}{|l|}{ Male } \\
\hline Informal Transfers & 7.2 & 10,061 & 2633 & 100.0 & 46.0 & 9.1 & 19,975 & 2496 & 100.0 & 48.9 \\
\hline Informal Loans & 10.7 & 4,366 & 414 & 100.0 & 29.8 & 10.9 & 11,812 & 2680 & 100.0 & 34.7 \\
\hline Relative Loans & 5.3 & 4,084 & 540 & 46.0 & 13.7 & 4.6 & 17,297 & 5352 & 61.3 & 21.2 \\
\hline Non-Relative Loans & 6.4 & 3,930 & 361 & 54.0 & 16.1 & 7.7 & 6,501 & 1126 & 38.7 & 13.4 \\
\hline Formal Loans & 7.0 & 5,454 & 882 & 100.0 & 24.2 & 7.2 & 8,473 & 957 & 100.0 & 16.4 \\
\hline All Microcredit & 4.3 & 5,086 & 265 & 57.8 & 14.0 & 3.9 & 7,102 & 491 & 45.7 & 7.5 \\
\hline Program Loans & 4.1 & 5,171 & 264 & 55.1 & 13.4 & 2.8 & 8,152 & 591 & 37.8 & 6.2 \\
\hline BRAC & 0.6 & 4,523 & 662 & 7.6 & 1.8 & 0.3 & 7,826 & 2525 & 3.3 & 0.5 \\
\hline BRDB & 2.3 & 4,789 & 302 & 29.5 & 7.1 & 0.8 & 6,530 & 978 & 9.0 & 1.5 \\
\hline GB & 1.1 & 6,385 & 589 & 18.1 & 4.4 & 1.7 & 8,990 & 774 & 25.5 & 4.2 \\
\hline Other Microcredit & 0.3 & 3,419 & 936 & 2.7 & 0.6 & 1.1 & 4,388 & 916 & 7.9 & 1.3 \\
\hline Other Formal Loans & 2.7 & 5,986 & 2255 & 42.2 & 10.2 & 3.3 & 10,084 & 1999 & 54.0 & 8.9 \\
\hline Government & 1.2 & 4,452 & 460 & 14.4 & 3.5 & 1.7 & 8,259 & 780 & 23.0 & 3.8 \\
\hline Non-Government & 1.4 & 7,295 & 4115 & 27.7 & 6.7 & 1.8 & 10,618 & 3193 & 31.0 & 5.1 \\
\hline
\end{tabular}

Source: Authors' tabulations from the 1991/92 and 1998/99 World Bank/BIDS survey of rural Bangladesh.

General Notes: Weights are used to adjust the choice-based sample to random sample proportions. Columns may not add up due to rounding. See text for category definitions.

${ }^{1}$ Mean provides the average cumulative amount (1995 Tk.) that a household received, for households with non-zero values. Average 1995 Tk./US $\$$ exchange rate is 40.278.

${ }^{2}$ Percentages are calculated based on the total value received (accounting for the percentage of households receiving and average amount received). 
Figure 7. Formal and Informal Gifts and Loans by Survey Wave

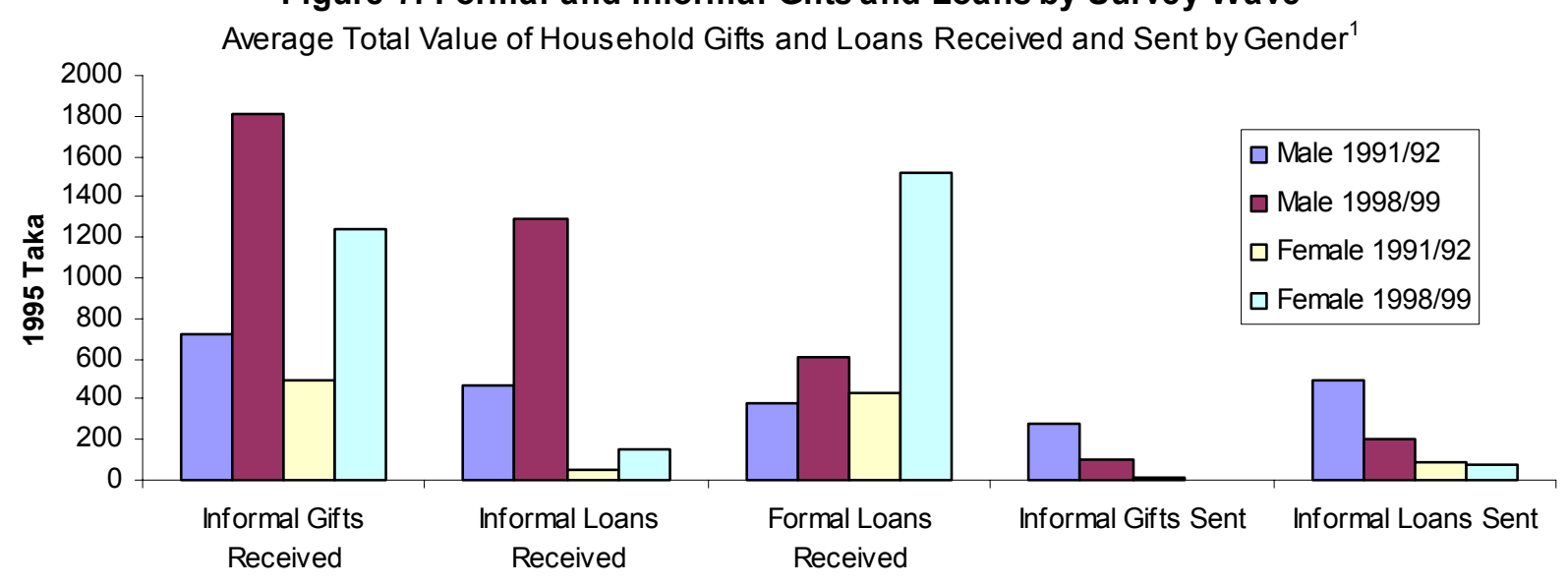

Source: Authors' w eighted tabulations from the 1991/92 and 1998/99 World Bank/BIDS survey of rural Bangladesh

${ }^{1}$ Average values are for both recipient and non-recipient households.

In real terms, the formal and informal sectors grew for both men and women between 1991/92 and 1998/99. Figure 7 shows the increase in informal gifts and loans and formal loans received by men and women. Overall, the average household value of informal gifts and loans rose approximately 250 percent for both men and women while the formal loan value increased roughly 1.5 times for men and 3.5 times for women (not shown). Thus there was strong growth in both financials sectors for men and women in Bangladesh. At the same time, there was a large decline in informal sector giving and lending for both males and females. Men gave less than half (38 percent) the value of gifts and loans in 1998/99 as they did in 1991/92 while women also sent less informal money (73 percent, not shown). Most of this decline occurred in the form of gifts sent as opposed to loans sent by both males and females.

Within the informal sector, the total value of gifts and loans received from males increased substantially. Gifts and loans from males to other males and from males to females grew by over 2.5 times between 1991/92 and 1998/99 (not shown). Most of this increase can be attributed to the significant increases in average gift and loan sizes received from men (Table 14). While the percentage of gifts and loans received by men and women remained steady, men played a greater role in sending in the informal sector, especially with respect to gifts. Figure 8 exhibits the increased male role in the flow of informal gifts. As females focused more on formal sector loans, males became more heavily involved in the informal sector acting as the primary receivers and senders of informal gifts and loan in rural Bangladesh. 
TABLE 14 - Informal Gifts and Loans by Sex of Sender and Receiver

\begin{tabular}{|c|c|c|c|c|c|c|}
\hline & \multicolumn{3}{|c|}{ Wave 1: 1991/92 } & \multicolumn{3}{|c|}{ Wave 2: 1998/99 } \\
\hline & $\%$ HH Received & Mean $^{1}$ & Standard Error & $\%$ HH Received & Mean $^{1}$ & Standard Error \\
\hline \multicolumn{7}{|l|}{ Relative Gifts } \\
\hline Female-to-Female & $2.1 \%$ & 1,488 & 587 & $0.3 \%$ & 5,463 & 2488 \\
\hline Female-to-Male & $0.8 \%$ & 12,548 & 8526 & $0.9 \%$ & 6,970 & 1693 \\
\hline Male-to-Female & $6.8 \%$ & 6,727 & 1475 & $5.5 \%$ & 22,223 & 2819 \\
\hline Male-to-Male & $6.5 \%$ & 9,564 & 2704 & $8.4 \%$ & 20,679 & 2660 \\
\hline \multicolumn{7}{|l|}{ Relative Loans } \\
\hline Female-to-Female & $0.1 \%$ & 1,437 & 181 & $0.3 \%$ & 3,852 & 1442 \\
\hline Female-to-Male & $0.9 \%$ & 2,923 & 979 & $1.1 \%$ & 6,109 & 2283 \\
\hline Male-to-Female & $0.4 \%$ & 4,240 & 2704 & $1.0 \%$ & 7,036 & 2593 \\
\hline Male-to-Male & $4.5 \%$ & 4,190 & 595 & $3.7 \%$ & 19,558 & 6398 \\
\hline \multicolumn{7}{|l|}{ Non-Relative Loans } \\
\hline Female-to-Female & $0.0 \%$ & 0 & 0 & $0.5 \%$ & 3,598 & 999 \\
\hline Female-to-Male & $0.8 \%$ & 2,914 & 1070 & $0.9 \%$ & 3,685 & 901 \\
\hline Male-to-Female & $0.7 \%$ & 4,072 & 805 & $0.4 \%$ & 11,465 & 6843 \\
\hline Male-to-Male & $5.8 \%$ & 3,958 & 378 & $6.4 \%$ & 6,957 & 1331 \\
\hline
\end{tabular}

Source: Authors' tabulations from the 1991/92 and 1998/99 World Bank/BIDS survey of rural Bangladesh.

General Notes: Weights are used to adjust the choice-based sample to random sample proportions. The sex of the gift or loan source is missing in certain cases.

${ }^{1}$ Mean provides the average cumulative amount (in 1995 Taka) that a household received, for households with nonzero values. Average 1995 Tk./U.S. \$ exchange rate is 40.278 .

Figure 8. Share of Total Informal Gifts and Loans Received by Sex of Sender and Receiver Wave 1 vs. Wave 2

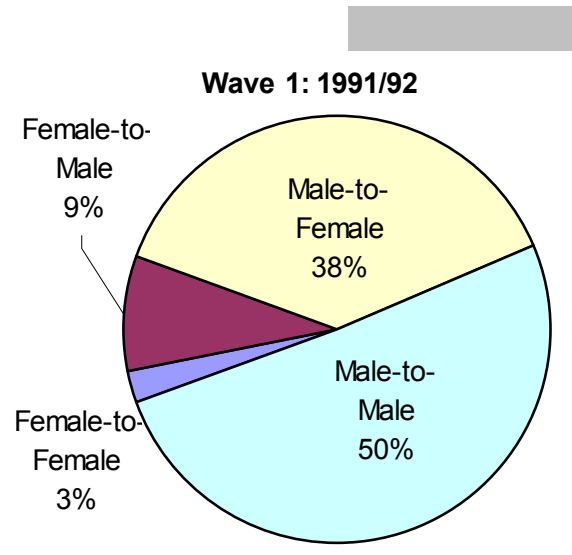

\section{Gifts}
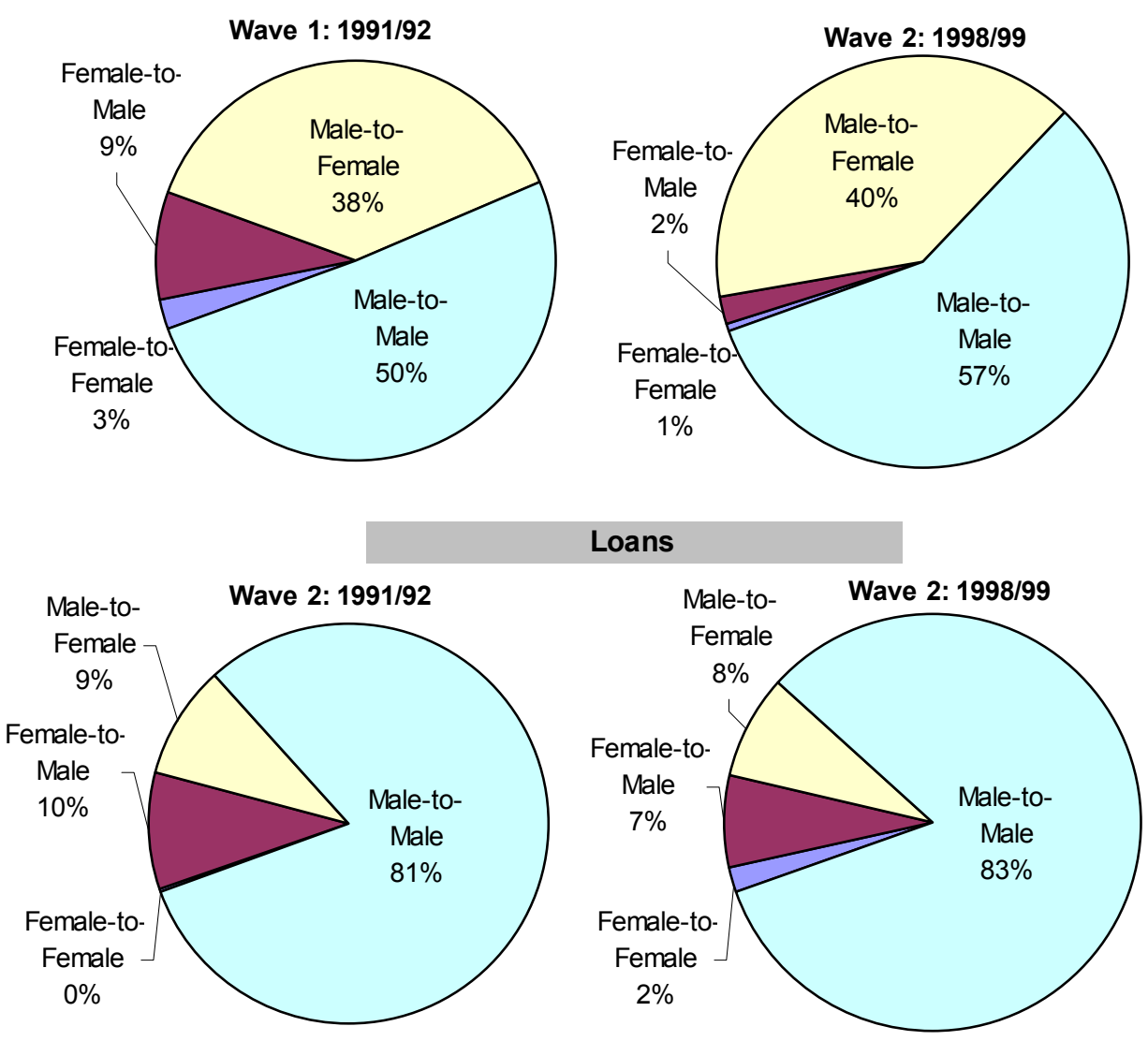

Source: Authors' w eighted tabulations from the 1991/92 and 1998/99 World Bank/BIDS survey of rural Bangladesh 


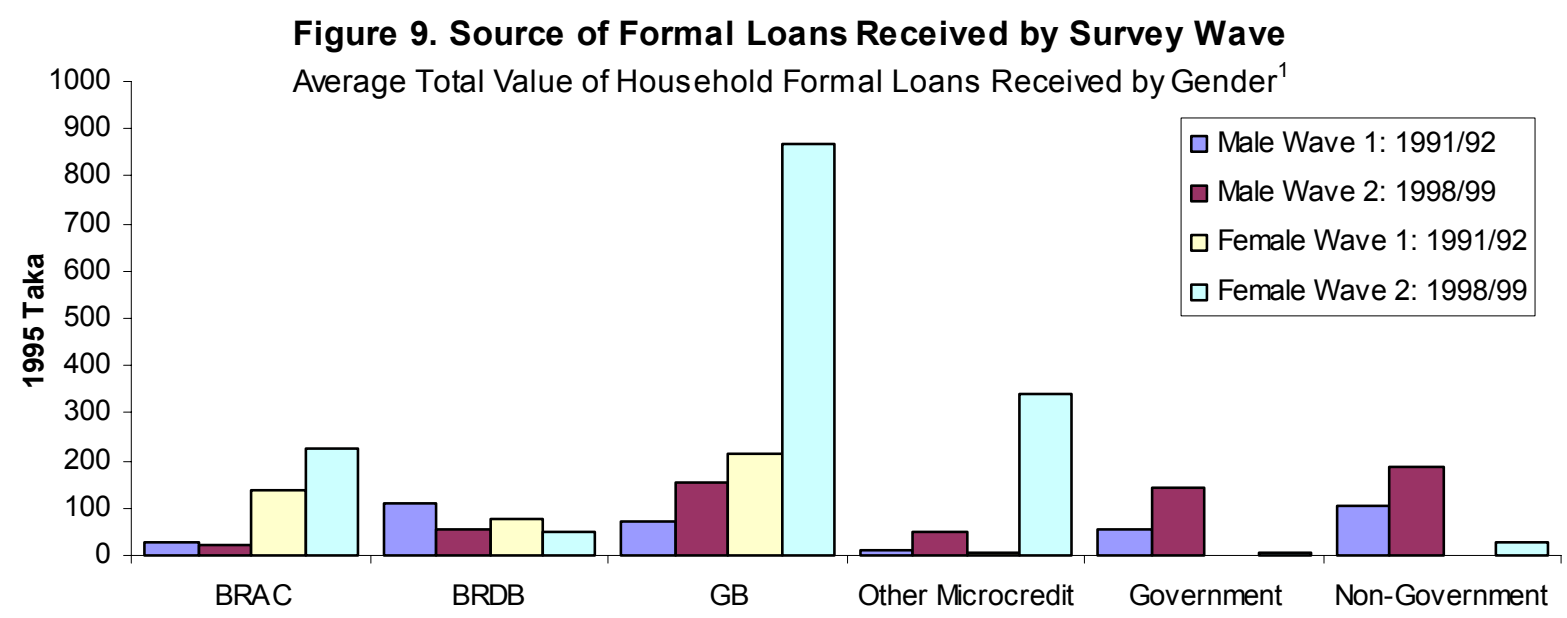

Source: Authors' w eighted tabulations from the 1991/92 and 1998/99 World Bank/BIDS survey of rural Bangladesh

${ }_{1}^{1}$ Average values are for both recipient and non-recipient households.

Women saw the largest rise in formal credit between 1991/92 and 1998/99, an increase that came almost entirely from microcredit organizations (Figure 9). Female microcredit loans increased significantly both in the average loan amount and the percentage of households receiving them. Nearly a quarter ( 23 percent) of all households had women receive a loan from a microcredit organization in 1998/99 compared with only nine percent in 1991/92 (Table 13). The increase was especially large for other microcredit organizations and the Grameen Bank. While the bulk of the formal credit increase came from microcredit organizations, women saw a slight rise in government and non-government formal loans between waves. During the first wave of the survey, there were no non-microcredit formal loans to women, but in 1998/99 both government and non-government institutions sent a few loans to females (though still only reaching less than 1 percent of households).

Men also received more money from formal sources in 1998/99 than they did in 1991/92, however the increase was notably smaller for men than for women. Most of the increase for men came from government and non-government institutions. While the percentage of households with men receiving loans from these sources remained relatively steady, the average loan size increased significantly (Table 13). As a result, men doubled the money they received in government and non-government loans during the seven-year period (Figure 9). Male microcredit lending remained rather stable between 1991/92 and 1998/99, increasing roughly 25 percent over that time span. Overall, males in rural Bangladesh saw an increase in both microcredit and non-microcredit formal lending, however this rise was minimal in comparison to the increases received by females from formal sources and with the expansion of the male informal financial sector. 


\section{Section V. Regression Results}

We turn to regressions to begin to investigate whether the formal financial sector crowds out the informal financial sector in rural Bangladesh. This analysis uses the 1991/92 wave of the data to estimate the impact of credit from the formal sector, by gender, on informal sector behavior. We use the 1991/92 wave as our starting point because the identification strategy is more straightforward than it would be with the later wave. In the first wave households more closely followed the quasi-experimental survey design framework used to identify program effects. Future work on this project will use both survey waves to further analyze the relationship between the formal and informal sectors.

In this analysis, we focus more narrowly on program credit as our measure of formal credit for two reasons. First, as noted, microcredit accounted for 80 percent of all formal loans in rural Bangladesh and is essentially the only form of formal credit that women receive. Second, as mentioned in the data section, the survey design enables us to causally identify the impact of program credit. Program credit is defined as the cumulative amount of all loans (greater than or equal to 1,000 Taka) received from the three (Grameen Bank, BRAC, BRDB) credit programs in the past six years.

We focus more narrowly on credit and transfers from relatives as our measure of the informal sector. Relative credit and transfers include cash and the value of all food and other inkind assistance sent from (received by) any member of the household to (from) someone living away from the household, and all loans made to (received from) relatives over the past year. ${ }^{19}$ We use this slightly narrower definition because informal gifts and loans are predominantly sent between relatives. We also expect relatives to be more altruistically linked and so more likely to respond to changes in formal credit received by a household.

Theory leaves the impact of program credit on credit and transfers from relatives unsigned. Program credit may substitute for transfers and other sources of credit, but they may also be complements. The receipt of program credit could increase borrowing from other sources of credit if program credit provides capital that could be used as collateral, or if it signals to other lenders that a household is creditworthy.

\section{Estimation Strategy}

We present estimates below of the impact of program credit on relative credit and transfers. The model we estimate is described in simple terms here by equations (1) and (2). The equation for the outcome $\mathrm{y}_{\mathrm{ij}}$, (e.g., the censored variable of relative credit and transfers received for household $i$ in village $j$ ), is a function of the amount of program credit the household borrows $\mathrm{C}_{\mathrm{ij}}$, a vector $\mathrm{X}_{\mathrm{ij}}$ of household characteristics, (such as land holdings and the age, sex, and education of the household head), unknown parameters $\beta_{\mathrm{y}}$ and $\delta$, unmeasured, fixed, village-

\footnotetext{
${ }^{19}$ Households that had cumulative informal transfers of less than 100 Taka over the past year were treated as though they had zero transfers. Transfers of less than 100 Taka are too small to be related to microcredit loans, which include any loans of over 1,000 Taka, and likely represent a different behavior.
} 
level determinants of relative credit and transfers (such as how remote or poor a village is) $\mu_{j}^{v}$, and a nonsystematic error $\varepsilon_{i j}^{y}$ reflecting, in part, unmeasured determinants of $\mathrm{y}_{\mathrm{ij}}$ that vary over households.

$$
\mathrm{y}_{\mathrm{ij}}=\mathrm{X}_{\mathrm{ij}} \beta_{y}+\mathrm{C}_{\mathrm{ij}} \delta+\mu_{\mathrm{j}}^{y}+\varepsilon_{\mathrm{ij}}^{y}
$$

The reduced form equation (2) measures the amount of program credit borrowed $\mathrm{C}_{\mathrm{ij}}$. Program credit borrowed is a function of household characteristics $X_{\mathrm{ij}}$ and a set of household or village characteristics $Z_{\mathrm{ij}}$ distinct from the $\mathrm{X}_{\mathrm{ij}}$ 's in that they affect $\mathrm{C}_{\mathrm{ij}}$ but not other household behaviors conditional on $\mathrm{C}_{\mathrm{ij}}$ (see below). $\beta_{\mathrm{c}}$ and $\pi$ are unknown parameters, $\mu_{j}^{c}$ is an unmeasured determinant of $\mathrm{C}_{\mathrm{ij}}$ that is fixed within a village, and $\varepsilon_{i j}^{c}$ is a nonsystematic error that reflects unmeasured determinants that vary over households.

$$
C_{i j}=X_{i j} \beta_{c}+Z_{i j} \pi+\mu_{j}^{c}+\varepsilon_{i j}^{c}
$$

The estimation issue arises as a result of the possible correlation of $\mu_{j}^{c}$ with $\mu_{j}^{y}$, and of $\varepsilon_{i j}^{c}$ with $\varepsilon_{i j}^{y}$. Econometric estimation that does not take these correlations into account may yield biased estimates of the parameters of equation (1) due to the endogeneity of credit program participation $\mathrm{C}_{\mathrm{ij}}$. It may be that unmeasured attributes that affect credit program participation also affect the amount of relative credit and transfers that households send and receive. For example, households may self-select into the programs. The households who choose to join microcredit programs may be the ones who have less access to transfers and other sources of credit. Ignoring this self-selection would wrongly ascribe to the credit program the lower amount of relative credit and transfers that program participants receive. It is also likely that programs are not randomly placed. Programs may be placed in poorer or more remote villages and households in poorer or more remote villages may send fewer transfers.

The standard approach to the problem of estimating equations with endogenous regressors, such as equation (1), is to use instrumental variables. In the model set out above, the exogenous regressors $Z_{\mathrm{ij}}$ in equation (2) are the identifying instruments. Unfortunately, it is difficult to find any regressors $Z_{\mathrm{ij}}$ that can justifiably be used as identifying instrumental variables. Lacking identifying instruments $Z_{\mathrm{ij}}$, the sample survey was constructed so as to provide identification through a quasi-experimental design.

To identify the effect of program credit on relative credit and transfers, when program credit is endogenous, we must control for the common village- and household-specific unobservables and have exogenous variation in our program credit variable. The approach we take is that used by Pitt and Khandker (1998). We use limited information maximum likelihood to jointly estimate the relative credit/transfer and program credit equations, thereby controlling for the correlation of the error terms between the two equations. We use village-level fixedeffects to remove the source of correlation between program placement and the behavior of interest, in this case, informal credit and transfers.

The exogenous variation necessary to identify the impact of program credit comes from the quasi-experimental nature of the program eligibility criteria. This variation comes from 
households who were excluded from participating by an exogenous participation rule. That rule is the restriction that households owning more than 0.5 acres of cultivable land are precluded from joining any of the three credit programs under study in this analysis. The half an acre land rule acts to exogenously separate households into quasi-experimental treatment and control groups. Owning half an acre of land affects whether a household participates in the credit program because it is the arbitrary point chosen for the program rule. However owning half an acre of land should not affect whether a household receives credit or transfers from relatives. We would expect landholding to affect transfers and credit from relatives in a more continuous manner.

Households owning slightly more than half an acre of land serve as a control group with which to compare households that receive the treatment of program credit. Identification on the basis of land ownership requires that land ownership be exogenous to the population studied, in this case, households in rural Bangladesh. Market sales of land in South Asia are well documented to be low. As a result, land ownership is treated as an exogenous regressor in most empirical work on household behavior in South Asia. ${ }^{20}$

Morduch (1998) raises the issue of mistargeting in these data. There are a number of households in our sample that are program participants yet had more than 0.5 acres of land at the time of program entry, raising the possibility of mistargeting and potential bias in econometric results relying on this targeting rule. It appears that some of this excess land is either uncultivable or marginally so. Pitt (1999) demonstrates that the value per acre of land owned by program participating households who also own more than 0.5 acres of cultivable land at the time of joining is a small proportion of the value per acre of the cultivable land of program participants owning less than 0.5 acres of cultivable land at the time of joining. This suggests that program officers are using some notion of "effective" units of cultivable land in determining eligibility rather than the type of mistargeting that would result in econometric bias. Pitt (1999) discusses this issue at length and demonstrates that treating the exogenous targeting rule as greater than 0.5 acres provides a consistent estimator for certain types of mistargeting. He finds that application of targeting rules greater than 0.5 acres (up to 2.0 acres) actually slightly strengthens the qualitative results on the effect of credit by gender on household consumption. In that paper and in Pitt (2001), results are very insensitive to possible mistargeting. McKernan (2002) also tests the sensitivity of her results to mistargeting. She finds that two out of the three microcredit programs are robust to all mistargeting sensitivity tests and that all three programs have large effects on self-employment for the landless poor.

To illustrate the identification strategy, consider a sample drawn from two villages village 1 does not have the program and village 2 does; and, two types of households, landed $\left(\mathrm{X}_{\mathrm{ij}}=1\right)$ and landless $\left(\mathrm{X}_{\mathrm{ij}}=0\right)$. Innocuously, we assume that landed status is the only observed household-specific determinant of relative credit and transfers $\mathrm{y}_{\mathrm{ij}}$ in addition to any treatment effect from the program. The conditional demand equation is:

\footnotetext{
${ }^{20}$ The validity of the assumption that land ownership is exogenous is defended at length in Pitt and Khandker (1998).
} 
$y_{i j}=C_{i j} \delta+X_{i j} \beta_{y}+\mu_{j}^{y}+\varepsilon_{i j}^{y}$

The exogeneity of land ownership is the assumption that $\mathrm{E}\left(X_{i j}, \varepsilon_{i j}^{y}\right)=0$, that is, that land ownership is uncorrelated with the unobserved household-specific effect. The expected value of $\mathrm{y}_{\mathrm{ij}}$ for each household type in each village is:

$\mathrm{E}\left(\mathrm{y}_{\mathrm{ij}} \mid \mathrm{j}=1, \mathrm{X}_{\mathrm{ij}}=0\right)=\mu_{1}^{y}$

$\mathrm{E}\left(\mathrm{y}_{\mathrm{ij}} \mid \mathrm{j}=1, \mathrm{X}_{\mathrm{ij}}=1\right)=\beta_{\mathrm{y}}+\mu_{1}^{y}$

$\mathrm{E}\left(\mathrm{y}_{\mathrm{ij}} \mid \mathrm{j}=2, \mathrm{X}_{\mathrm{ij}}=1\right)=\beta_{\mathrm{y}}+\mu_{2}^{y}$

$\mathrm{E}\left(\mathrm{y}_{\mathrm{ij}} \mid \mathrm{j}=2, \mathrm{X}_{\mathrm{ij}}=0\right)=\overline{\mathrm{C}}_{\mathrm{ij}} \delta+\mu_{2}^{y}$

where $\overline{\mathrm{C}}_{\mathrm{ij}}$ is the mean amount of program credit borrowed among landless households in village 2 who choose to participate in the program. It is clear that all the parameters, including the effect of the credit program $\delta$, are identified from this design. ${ }^{21}$ In particular, the estimator of the program effect $\delta$ is a variant of the difference-in-differences estimator widely applied in the general program evaluation literature. To see this, note that an estimate of $\delta$ is obtained from the following difference-in-differences: ${ }^{22}$

$\left[E\left(y_{i j} \mid j=2, X_{i j}=0\right)-E\left(y_{i j} \mid j=2, X_{i j}=1\right)\right]-\left[E\left(y_{i j} \mid j=1, X_{i j}=0\right)-E\left(y_{i j} \mid j=1, X_{i j}=1\right)\right]$

Even if land ownership is exogenous for the purposes of this analysis, it is necessary that the "landless" and the "landed" can be pooled in the estimation. To enhance the validity of this assumption, we restrict the set of nontarget households used in the estimation to those with less than five acres of owned land. In addition, we include the quantity of land owned as one of the regressors in the vector $\mathrm{X}_{\mathrm{ij}}$ and include a dummy variable indicating the target/nontarget status of the household.

The exclusion restrictions that identify the effects of program credit on relative credit and transfers $y_{\mathrm{ij}}$ are the interactions of a dummy variable indicating if the household has the choice to join the credit program (which requires meeting the land ownership rule and residing in a village with a credit program) and all the exogenous variables of the model, $\mathrm{X}_{\mathrm{ij}}$ and $\mu_{\mathrm{j}}$. Consequently, the model is not nonparametrically identified.

Additional identification restrictions are required when there are both male and female credit programs with possibly different effects on behavior. Identification of gender-specific credit is achieved by making use of another quasi-experimental attribute of these programs and

\footnotetext{
${ }^{21}$ Data from nonprogram villages is required for identification if $\mathrm{X}$ is a binary indicator of landed status. If landed status is a continuous measure of landholding, then the model is identified without information on behavior in nonprogram villages. That is, (4a) and (4b) are not required. In this case, the parameter $\beta_{\mathrm{y}}$ in (3) is identified from variation in landholding within the program villages $(\mathrm{j}=2)$.

${ }^{22}$ However, as Pitt (1999) points out, since this is a quasi-experiment, not an actual experiment, the direct application of (4e) would most likely result in a downward biased estimate of $\delta$. The regression approach applied here is quite necessary to control for differences in other observed and unobserved variables across the four groups identified in equations (4a) through (4d).
} 
the survey. All program groups are single-sex and not all villages have both a male and a female group. The sample includes some households from villages with only female credit groups, so that males in landless households are denied the choice of joining a credit program, and some households from villages with only male credit groups, so that landless females are denied program choice. In particular, of the 87 villages in the wave 1 sample, 15 had no credit program, 40 had credit-groups for both females and males, 22 had female-only groups and 10 had maleonly groups. The necessary assumption is that the availability of a credit group by gender in a village is uncorrelated with the household errors $\varepsilon_{i j}^{y}$, conditional on $\mathrm{X}_{\mathrm{ij}}$ and the village fixed effects $\mu \mathrm{j}$. As each village had only one type of credit program available, and it is assumed that the type of credit program (BRDB, BRAC or Grameen) is uncorrelated with the household errors $\varepsilon_{i j}^{y}$, conditional on $\mathrm{X}_{\mathrm{ij}}$ and the village fixed effects $\mu_{\mathrm{j}}$, there is no need to model which of the programs members of a household join. Controlling for the endogeneity of program credit by gender adds an additional equation to the model. While we've described the main model with equations (1) and (2), we actually estimate three equations, a trivariate tobit, one equation for female program credit, one for male program credit, and one for the outcome, e.g., relative credit and transfers received.

\section{Empirical Results}

Informal credit and transfers from relatives are disaggregated between those received and those sent in the estimations reported below. ${ }^{23}$ One could construct "net received" as equal to credit and transfers received less credit and transfers sent, though using this variable imposes restrictions on the parameters on the reduced form determinants of relative credit and transfers sent and received. Constructing net received results in a variable taking both negative and positive values with a mass point at zero. The Tobit model can be generalized to allow a dependent variable of this form. In this preliminary work, we treat relative credit and transfers received and relative credit and transfers sent as separate Tobit-like dependent variables. As microcredit is also Tobit-like with a mass at zero, the resulting maximum likelihood procedures used is instrumental variables trivariate Tobit.

Two other aspects of the estimation method are worth noting. First, the sample design is choice-based. In particular, program participants are purposely over-sampled. The Weighted Exogenous Sampling Maximum Likelihood (WESML) methods of Manski and Lerman (1977) were used in the estimation of both parameters and the parameter covariance matrix. WESML estimates are obtained by maximizing a weighted log likelihood function with weights for each choice equal to the ratio of the population proportion to the sample proportion for that choice.

Second, only households in villages that have access to a group-based credit program, and meet the (exogenous) eligibility criteria can choose whether to join a credit group and decide how much to borrow. If credit program placement across the villages of Bangladesh is attentive to the village effects $\mu_{\mathrm{j}}$, as Pitt and Khandker (1998) demonstrate, then selection bias will result. Estimating village fixed effects sweeps out the village errors correlated with program placement.

23 Due to the limited number of informal female credit and transfers (as reported descriptively), we are unable to disaggregate relative credit and transfers by gender. 
To ease the computational burden, and because the number of households reporting transfers and credit from relatives in each village is relatively small (and sometimes zero), we use thana fixed effects in the conditional relative credit/transfer equations. There are three villages, all with the same type of credit program, in each of the 24 program thanas.

Table 15 presents estimates of the impact of the log of program credit on the log of relative credit and transfers received. Column (1) presents estimates of program effects disaggregated by program (BRAC, BRDB and Grameen Bank) and by gender. ${ }^{24}$ The only statistically significant parameter among the six program parameters is for female borrowing from the Grameen Bank. Test statistics at the bottom of the column reveal that all three microcredit programs do not have different effects for female or male participants, but there is some evidence that female programs effects differ from male program effects. In column (2), we impose the restriction that program effects are the same across program types for each gender. The equality of the female and male program effect is rejected $\left(\chi^{2}=4.94, p=0.03\right)$. Tests of the exogeneity of female and male credit in the determination of relative credit and transfers received are t-tests of the associated error correlation coefficients $\rho$. Neither $\rho$ in column (2) is statistically different from zero at common levels of significance. Consequently, in column (3) we present the preferred estimates that impose both exogeneity and equal affects across program types. In column (3), there is strong evidence that program credit provided women over the past six years is a substitute for the receipt of relative credit and transfers, but no evidence that this is the case for borrowing by men. The latent elasticity of relative credit and transfers received with respect to female program credit is $-0.162(\mathrm{t}=3.599)$. Program credit provided to women results in a decrease in relative credit and transfers received from relatives.

The impact of program credit on credit and transfers sent to relatives is presented in Table 16. In column (1), with disaggregated programs by gender, there seem to be strong and positive effects of male program credit on the sending of credit and transfers to family relations. The tests at the bottom of the table reveal that, for both men and women, program type does not matter. Column (2) aggregates the three program types into one for each gender. In column (2), a test of the null hypothesis that women's program credit is exogenous in the determination of credit and transfers from relatives sent cannot be rejected $(\rho=0.056, t=0.397)$, but the analogous test for male program credit yields a rejection $(\rho=-0.273, t=-2.622)$. The negative $\rho$ for men suggests that men who tend to borrow from these microcredit programs tend to send fewer gifts and loans than nonborrowers, conditional on the regressors. The point estimate of the $\rho$ for males in the relative credit and transfers received conditional demand equation is also negative, although not statistically different from zero $(\rho=-0.161, t=-1.217)$, suggesting that men who join these credit program engage in less informal credit and transfer behavior than program nonparticipators. This is consistent with the descriptive findings suggesting that households who engage in formal transfer behavior are less likely to engage in informal transfer behavior. There is no noticeable pattern in these unobservables among women.

${ }^{24}$ The full set of coefficients are presented and briefly discussed in the Appendix. 
TABLE 15 - Estimates of the Impact of Log Program Credit on Log Relative Credit and Transfers Received

Maximum Likelihood Estimates

\begin{tabular}{|c|c|c|c|}
\hline & $\begin{array}{l}\text { By gender and program: } \\
\text { all endogenous } \\
\text { (1) }\end{array}$ & $\begin{array}{l}\text { By gender: } \\
\text { all endogenous } \\
\text { (2) }\end{array}$ & $\begin{array}{c}\text { By gender: } \\
\text { exogeneity imposed } \\
\text { (3) }\end{array}$ \\
\hline Log of amount borrowed by female from BRAC & $\begin{array}{c}-0.168 \\
(-1.472)\end{array}$ & & \\
\hline Log of amount borrowed by male from BRAC & $\begin{array}{c}0.095 \\
(0.760)\end{array}$ & & \\
\hline Log of amount borrowed by female from BRDB & $\begin{array}{l}-0.189 \\
(-1.588)\end{array}$ & & \\
\hline Log of amount borrowed by male from BRDB & $\begin{array}{c}0.022 \\
(0.208)\end{array}$ & & \\
\hline Log of amount borrowed by female from GB & $\begin{array}{l}-0.321 \\
(-2.734)\end{array}$ & & \\
\hline Log of amount borrowed by male from GB & $\begin{array}{c}0.198 \\
(1.342)\end{array}$ & & \\
\hline $\begin{array}{l}\text { Log of amount borrowed by female from BRAC, BRDB, or } \\
\text { GB }\end{array}$ & & $\begin{array}{l}-0.225 \\
(-2.252)\end{array}$ & $\begin{array}{l}-0.162 \\
(-3.599)\end{array}$ \\
\hline $\begin{array}{l}\text { Log of amount borrowed by male from BRAC, BRDB, or } \\
\text { GB }\end{array}$ & & $\begin{array}{c}0.101 \\
(0.991)\end{array}$ & $\begin{array}{c}0.011 \\
(0.226)\end{array}$ \\
\hline$\rho$ (women) & $\begin{array}{c}0.121 \\
(0.780)\end{array}$ & $\begin{array}{c}0.120 \\
(0.782)\end{array}$ & 0 \\
\hline$\rho$ (men) & $\begin{array}{l}-0.130 \\
(-0.978)\end{array}$ & $\begin{array}{l}-0.161 \\
(-1.217)\end{array}$ & 0 \\
\hline Number of observation & 1726 & 1726 & 1726 \\
\hline $\begin{array}{l}\text { Wald test }(x 2) \text { statistic for: } \\
\text { Equality of programs effects across genders: }\end{array}$ & $\begin{array}{c}7.55 \\
p=0.06\end{array}$ & $\begin{array}{c}4.94 \\
p=0.03\end{array}$ & $\begin{array}{c}6.45 \\
p=0.01\end{array}$ \\
\hline Equality of effects across programs (females) & $\begin{array}{c}2.29 \\
p=0.32\end{array}$ & & \\
\hline Equality of effects across programs (males) & $\begin{array}{c}2.14 \\
p=0.34\end{array}$ & & \\
\hline
\end{tabular}

$\mathrm{p}=0.34$

Source: Authors' weighted regressions from the 1991/92 World Bank/BIDS survey of rural Bangladesh. General Notes: Figures in parentheses are asymptotic t-ratios. Presents only selected regressors. 
TABLE 16 - Estimates of the Impact of Log Program Credit on Log Relative Credit and Transfers Sent Maximum Likelihood Estimates

\begin{tabular}{|c|c|c|c|}
\hline & $\begin{array}{l}\text { By gender and } \\
\text { program: } \\
\text { all endogenous } \\
\text { (1) }\end{array}$ & $\begin{array}{l}\text { By gender: } \\
\text { all endogenous } \\
\text { (2) }\end{array}$ & $\begin{array}{l}\text { By gender: } \\
\text { exogeneity imposed } \\
\text { for women } \\
\text { (3) }\end{array}$ \\
\hline Log of amount borrowed by female from BRAC & $\begin{array}{c}0.074 \\
(0.788)\end{array}$ & & \\
\hline Log of amount borrowed by male from BRAC & $\begin{array}{c}0.247 \\
(2.401)\end{array}$ & & \\
\hline Log of amount borrowed by female from BRDB & $\begin{array}{l}-0.074 \\
(-0.581)\end{array}$ & & \\
\hline Log of amount borrowed by male from BRDB & $\begin{array}{c}0.334 \\
(3.117)\end{array}$ & & \\
\hline Log of amount borrowed by female from GB & $\begin{array}{l}-0.060 \\
(-0.528)\end{array}$ & & \\
\hline Log of amount borrowed by male from GB & $\begin{array}{c}0.305 \\
(2.698)\end{array}$ & & \\
\hline $\begin{array}{l}\text { Log of amount borrowed by female from BRAC, BRDB, } \\
\text { or GB }\end{array}$ & & $\begin{array}{c}0.029 \\
(0.325)\end{array}$ & $\begin{array}{c}0.056 \\
(1.187)\end{array}$ \\
\hline $\begin{array}{l}\text { Log of amount borrowed by male from BRAC, BRDB, or } \\
\mathrm{GB}\end{array}$ & & $\begin{array}{c}0.291 \\
(3.572)\end{array}$ & $\begin{array}{c}0.290 \\
(3.546)\end{array}$ \\
\hline$\rho$ (women) & $\begin{array}{c}0.075 \\
(0.550)\end{array}$ & $\begin{array}{c}0.056 \\
(0.397)\end{array}$ & 0 \\
\hline$\rho$ (men) & $\begin{array}{l}-0.281 \\
(-2.621)\end{array}$ & $\begin{array}{c}-0.273 \\
(-2.622)\end{array}$ & $\begin{array}{c}-0.272 \\
(-2.6042)\end{array}$ \\
\hline Number of observation & 1726 & 1726 & 1726 \\
\hline $\begin{array}{l}\text { Wald test }(x 2) \text { statistic for: } \\
\text { Equality of programs effects across genders: }\end{array}$ & $\begin{array}{c}8.23 \\
p=0.04\end{array}$ & $\begin{array}{c}4.79 \\
p=0.03\end{array}$ & $\begin{array}{c}6.51 \\
p=0.01\end{array}$ \\
\hline Equality of effects across programs (females) & $\begin{array}{c}2.30 \\
p=0.32\end{array}$ & & \\
\hline Equality of effects across programs (males) & $\begin{array}{c}0.63 \\
p=0.73\end{array}$ & & \\
\hline
\end{tabular}

Source: Authors' weighted regressions from the 1991/92 World Bank/BIDS survey of rural Bangladesh.

General Notes: Figures in parentheses are asymptotic t-ratios. Presents only selected regressors. 
In column (3) of Table 16 we present the preferred estimates which impose exogeneity where warranted and equality of treatment effects by program. The latent elasticity of relative credit and transfers sent with respect to program credit is $0.056(\mathrm{t}=1.187)$ for women and 0.290 $(t=3.546)$ for men. After controlling for the endogeneity of program credit-men who tend to borrow from these microcredit programs tend to send fewer gifts and loans than nonborrowersprogram credit provided men results in an increase in informal gifts and loans sent.

To interpret our results we calculate approximate marginal effects based on the latent elasticities and take the difference between the marginal effect of relative credit and transfers received and relative credit and transfers sent. We find that for households eligible to participate in microcredit programs, a 100 Taka increase in female program credit reduces net relative credit and transfers into the household by 25 Taka, and a 100 Taka increase in male program credit reduces net relative credit and transfers into the household by 31 Taka. Taking the results of Tables 15 and 16 together, we find that program borrowing by males and females results in a decrease in net relative credit and transfers received in the household because households receive fewer gifts and loans from relatives when a female borrows and send more gifts and loans to relatives when a male borrows.

Our finding that female program credit reduces credit and transfers received from relatives and male program credit increases credit and transfers sent to relatives, made perfect sense to the Grameen Bank official we discussed it with. He explained that transfers in Bangladesh typically go from males, the income earners, to females, and specifically from sons to parents. An increase in program credit to a female would reduce transfers to that household for two reasons: (1) the household would have more income and so need fewer transfers; and (2) children might backlash against a female who expresses an interest in being more independent by taking out a Grameen Bank loan. An increase in program credit to a male would increase transfers sent because that male would have more income to remit.

Our findings from the literature and our descriptive results help corroborate the Grameen Bank official's explanation. An increase in program credit will have potential income effectsthe household will have more income to spend and send as credit and transfers. An increase in program credit to women is more likely to result in increases in spending on education and food (maternal altruism) and no increase in credit and transfers sent because women in Bangladesh rarely send credit or transfers. An increase in program credit to men, on the other hand, is more likely to result in increases in credit and transfers sent, because men do send gifts and loans, typically to a father or widowed mother.

We can also infer from the literature, that an increase in program credit may crowd out income from informal transfers, if transfers are altruistically motivated. Our finding that informal transfers typically flow to poorer households is consistent with altruistic motives for sending transfers. Indeed, we do find that an increase in program credit to women reduces transfers received. An increase in program credit to men does not reduce transfers received because the younger men that typically receive program credit (37 year olds on average, Table 6) do not typically receive informal transfers. Older men ( 55 year olds on average, Table 6 ) are 
more likely to receive informal transfers, perhaps from their sons participating in microcredit programs. We also know from the literature that microcredit programs are associated with increased empowerment for women. Participating in a microcredit program could cause male sons to backlash against a mother who is violating purdah by going into public places to meet with male program staff and fellow female members, among other activities.

In summary, this preliminary causal model suggests that program credit and net credit and transfers from relatives are substitutes. Consequently the benefits of microcredit program borrowing seem to be shared by family relations through a change in net flows received by them. Future research will use both waves of the panel to measure crowding out. 


\section{Section VI. Conclusions and Policy Implications}

In 1998/99, rural Bangladesh appears to have had both prosperous formal and informal financial sectors. Roughly half of all households received a gift or loan from one or both sectors during the past year. The value of gifts alone amounted to nearly half of total household income, suggesting that these transfers are an important income source for the households that receive them. The demographic characteristics of households that did and did not receive a gift or loan were surprisingly similar, but some differences among recipients are evident. Households receiving informal loans had higher incomes on average, while households receiving informal gifts had lower incomes on average, and were more likely to be female headed and older. The reliance on the formal and informal sectors seems to have been relatively split with an informal sector that was at least as important as the formal sector.

Gifts and loans in the informal sector were predominantly sent between relatives and came most often in the form of cash (as opposed to in-kind). However, non-relatives still made up an important component of informal lending. Similar to findings in previous literature, households in rural Bangladesh received more than they sent through the informal financial sector. This is largely because households in our rural sample received the majority of their informal gifts in the form of remittances from abroad and transfers from urban areas.

While the informal sector was greater in total value than the formal sector, lenders in the formal sector were able to reach more households. The formal sector was dominated by microcredit organizations that accounted for 83 percent of formal loans. Today Bangladesh has the largest operation of microcredit programs in the world, with about 12.4 million active borrowers and over 629 NGOs engaged in microcredit (World Bank 2003, 21). These institutions sent relatively small loans in comparison with both non-microcredit loans and informal sector transactions, but they reached over a quarter of all households in rural Bangladesh in 1998/99.

A major finding of this analysis is the large difference between men and women in whom they depend upon to provide financial services. While women are relatively split between their reliance on the formal and informal financial sectors, men rely much more heavily on informal credit and transfers. The evidence points to an informal sector that is much less oriented to women than would be expected given previous results from other studies. In fact, the majority of informal gifts and loans flow between men in rural Bangladesh. Though some of this may be due to reporting, even reclassifying the gender of the recipient to correspond with the relationship to the sender does little to alter this finding. Data from the survey show that men received the majority of all informal gifts and over two-thirds of all informal loans. Men sent 95 percent of all gifts and loans. Men, typically older, primarily receive informal gifts from their children, siblings, and more distant relatives. While women typically receive informal gifts from spouses who are remitting from abroad or children. Overall, males relied on the informal sector 
for roughly 85 percent of all the gifts and loans they received, leaving only a limited role for the male formal sector.

Microcredit was a key source of money for women in rural Bangladesh, accounting for roughly half of all gifts and loans received by women and effectively acting as the only source of formal lending to women. While the total value of gifts and loans received from the formal and informal sectors was nearly equal for women, microcredit organizations reached nearly three times as many women as the informal sector. In comparison, only seven percent of women received an informal gift or loan during the past year, though these gifts were large - averaging roughly three times the size of both formal and informal loans. It appears that the female informal sector was mostly limited to informal transfers sent to widowed women or women whose spouses were temporarily away. As a result, informal credit comprised only 11 percent of the female informal sector, a sharp contrast to the 42 percent share for males.

The results show many different variations on the recipients of formal and informal finance, including similarities among the groups. However a few rough generalizations can be made:

- Informal transfer recipients in rural Bangladesh are typically:

1. Older married men receiving transfers from their children or siblings;

2. Relatively poor widowed women receiving transfers from their children;

3. Relatively poor married women receiving transfers from spouses who are temporarily away from the household.

- Informal transfer senders in rural Bangladesh are typically:

1. Male children, male spouses temporarily away from the household, and male siblings.

- Informal credit recipients in rural Bangladesh are typically:

1. Relatively wealthy men receiving loans from siblings, in-laws, and other more distant relatives;

2. Relatively wealthy men receiving loans from neighbors, friends, and other nonrelatives (employers, landlords, shopkeepers, ...).

- Formal credit recipients in rural Bangladesh are typically:

1. Women receiving loans from microcredit programs

Between 1991/92 and 1998/99, there was a substantial expansion of the formal and informal financial sectors in Bangladesh. During the seven-year period, the total value of informal gifts and formal and informal loans received grew by over 250 percent and the 
percentage of households receiving a gift or loan increased from 37 percent to 49 percent. Formal transfers increased 80 percent.

Though the growth was nearly equal in magnitude for both financial sectors, there were significant differences in the two expansions. Almost the entire increase in the informal sector can be ascribed to rises in loan sizes. Formal sector growth, on the other hand, was primarily led by a rise in the number of households receiving loans. Additionally, the expansions varied greatly by gender as women realized the majority of growth in the formal sector while males received slightly more of the informal sector expansion. Finally, while the value of informal gifts and loans received grew immensely, there was a drop in the value of informal credit and transfers sent. These changes occurred in the context of and can largely be explained by substantial economic growth, a large increase in microcredit programs, and a massive flood between the time periods.

Though men still receive a significantly larger amount of the credit and transfer money than women, the gap narrowed significantly during the 1990's. Overall, women saw a 300 percent growth in the formal and informal sectors, outpacing the 235 percent increase enjoyed by men. While almost all of the gain for men came through increases in gift and loan sizes, there was a considerable rise in the total percentage of women receiving gifts and loans (12 percentage points compared to one percentage point for men). In fact, in 1998/99, more households had females who received a gift or loan in the past year than had males who received them.

Evidence on the relationship between the formal and informal sectors is mixed. Even though nearly half of all households received a gift or loan in the past year, households in rural Bangladesh rarely received them from both the formal and informal sectors. Only 12 percent of households involved in the formal or informal sectors received money from both. Though the data clearly show that the majority of households do not rely on both sectors for credit and transfers, the reason for this behavior is not as clear. The descriptive evidence appears to show that formal credit is mostly reaching households who otherwise would not have access to the informal sector or who choose not to move from the corner of no informal sector use. However the descriptive results also show similarities between households receiving formal credit and informal credit and transfers (e.g., many come from the same income quintiles) suggesting that there is substantial overlap between these populations and thus potential for crowding out. The descriptive results also highlight that informal transfer recipients are slightly lower-income than non-recipients, suggesting that transfers may in part be altruistically motivated.

The regressions results suggest that the formal sector is partially crowding out the informal sector. We find that program borrowing by males and females results in a decrease in net credit and transfers from relatives received in the household because households receive fewer credit and transfers when a female borrows and send more credit and transfers when a male borrows. The descriptive differences that we do find between the types of households receiving formal credit and informal transfers help paint a potential story for our regression results. An increase in program credit to women results in fewer transfers to the household as male children and spouses temporarily away from the household send fewer transfers. The 
children and spouses send fewer transfers in response to the women's increased income (from the income from the milking cow a woman might purchase with the microcredit loan, for example) and in response to the potential shame women bring to the family by violating aspects of purdah in order to participate in microcredit programs. An increase in program credit to men results in increased transfers sent from the household as the men have more income (from driving the rickshaw they purchased with their microcredit loan, for example) to send to older fathers, widowed mothers, or siblings.

\section{Policy Implications}

With slightly more than half of all households and many poor households still receiving no gift or loan in the past year, there is plenty of room for growth in the financial sectors in the near future. Formal sector financial programs are one way to provide this growth.

However, the finding that the formal sector may partially crowd out the informal sector has important policy implications. First, the effects of public programs on beneficiaries may be less than originally intended, especially if the measure of welfare is restricted to income. Some of the benefits will be shared with third parties - those who send and receive informal transfers and credit. Second, as a result of the shared benefits, there are likely to be unmeasured third party impacts of new credit or transfer programs that are not being captured in existing impact measures. It is most likely that many of these third party impacts are positive. The programs will improve the welfare not just of program participants but of related non-participants. We find that microcredit recipients increase their transfer activity as a consequence of a loan. The recipient of that net transfer is likely to be another poor household since in a stratified society like Bangladesh, the landless poor are very unlikely to have "rich uncles." A consequence of ignoring third-party effects is an underestimate of program effects, and this underestimate can be large.

The gender-specific findings also have important policy implications. Evidence suggests that finances in the hands of women result in higher repayment rates, empowerment, and better outcomes - such as improved health and nutrition for both boys and girls. It is important for formal sector programs to target women in countries such as Bangladesh where few women receive gifts or loans from the informal sector. Microcredit programs have been successful in reaching women. As a result, women receive more loans from those organizations than men.

Our preliminary evidence indicates that all finances targeted to women will not necessarily remain in the hands of women. Formal loans to women reduce net transfers into the household. As men primarily send transfers, they may receive some of the benefits of female program participation. For example, the male children and spouses of female program participants will need to transfer less because the women now has her own source of income. Even though some of the income from female-targeted programs may be shared with men, programs targeting women are likely to shift financial resources and power within the household toward women. Similarly, formal finances targeted to men will not necessarily remain in the targeted household. Formal loans to men increase transfers sent out of the household. For 
example, fathers and siblings may receive some of the increased income from programs. These third parties (the fathers, siblings, children, and spouses, among others) and measures of their gender will need to be captured in order to assess the complete gender impacts of gendertargeted programs.

The few studies that have examined crowding out find only partial crowding out. Formal programs still provide the majority of benefits to their targeted populations. Additional research is necessary to better quantify the relationship between the formal and informal sectors by gender. Policymakers interested in targeting and program impacts should consider gender differences and the relationship between the formal and informal sectors. 


\section{References}

Altonji, Joseph, Fumio Hayashi, and Laurence Kotlikoff. 1992. "Is the Extended Family Altruistically Linked? Direct Tests Using Micro Data." The American Economic Review, 82, no. 5, December: 1177-98.

- 1996. The Effects of Income and Wealth on Time and Money Transfers Between Parent and Children, National Bureau of Economic Research Working Paper no. 5522. Cambridge, MA.

—. 1997. "Parental Altruism and Inter Vivos Transfers: Theory and Evidence." The Journal of Political Economy, 105, no. 6, December: 1121-66.

Barro, Robert J. 1974. "Are Government Bonds Net Wealth?" Journal of Political Economy, 82, no. 6, November-December: 1095-117.

Becker, Gary S. 1974. "A Theory of Social Interactions." Journal of Political Economy, 82, no. 6: 1063-93.

Bernheim, Douglas, Andrew Schleifer, and Lawrence Summers. 1985. "The Strategic Bequest Motive." The Journal of Political Economy, 93, no. 6, December: 1045-76.

Besley, Timothy J., Sanjay Jain, and Charalmbos Tsangarides. 2001. Household Participation in Formal and Informal Institutions in Rural Credit Markets in Developing Countries: Evidence from Nepal. Washington, DC: Background paper prepared for World Development Report 2001/2002: Institutions for Markets.

Bose, Pinaki. 1998. "Formal-Informal Sector Interaction in Rural Credit Markets." Journal of Development Economics, 56: 256-80.

Clarke, George, and Scott J. Wallsten. 2003. Do Remittances Act Like Insurance? Evidence from a Natural Disaster in Jamaica. Washington, D.C.: The World Bank Development Research Group.

Cox, Donald. 1987. "Motives for Private Income Transfers." Journal of Political Economy, 95, no. 3: 508-43.

-. 1990. "Intergenerational Transfers and Liquidity Constraints." Quarterly Journal of Economics, 105 (February): 187-217.

—. 2002. "Private Interhousehold Transfers in Vietnam in the Early and Late 1990s," Boston College Department of Economics, Boston, MA.

Cox, Donald, Zekeriya Eser, and Emmanuel Jimenez. 1998. "Motives for Private Transfers Over the Life Cycle: An Analytical Framework and Evidence for Peru." Journal of Development Economics, 55, no. 1, February: 57-80.

Cox, Donald, James Fetzer, and Emmanuel Jimenez. 1998. "Private Transfers in Vietnam." In Household Welfare and Vietnam's Transition, edited by D. Dollar, P. Glewwe, and J. Litvack. Washington, DC: World Bank.

Cox, Donald, and Tullio Jappelli. 1990. "Credit Rationing and Private Transfers: Evidence from Survey Data." Review of Economics and Statistics, 72, no. 3, August: 445-54.

Cox, Donald, and Emmanuel Jimenez. 1990. "Achieving Social Objectives Through Private Transfers: A Review." The World Bank Research Observer, 5, no. 2, July: 205-18.

-. 1992. "Social Security and Private Transfers in Developing Countries: The Case of Peru." The World Bank Economic Review, 6, no. 1: 155-69.

-. 1995. "Private Transfers and the Effectiveness of Public Income Redistribution in the Philippines." In Public Spending and the Poor: Theory and Evidence, edited by Dominique Van de Walle and Kimberly Nead, 321-46. Baltimore: Johns Hopkins University Press. 
—. 1998. "Risk Sharing and Private Transfers: What About Urban Households?" Economic Development and Cultural Change, 46 (April): 621-37.

Cox, Donald, Emmanuel Jimenez, and Wlodek Okrasa. 1997. "Family Safety Nets and Economic Transition: A Study of Worker Households in Poland." Review of Income and Wealth, 43, no. 2, June: 191-209.

Cox, Donald, and Mark R. Rank. 1992. "Inter-Vivos Transfers and Intergenerational Exchange." Review of Economics and Statistics, 74, no. 2, May: 305-14.

Floro, Maria, and Debraj Ray. 1997. "Vertical Links Between Formal and Informal Financial Institutions." Review of Development Economics, 1, no. 1: 34-56.

Foster, Andrew D., and Mark R. Rosenzweig. 2001. "Imperfect Commitment, Altruism, and the Family: Evidence from Transfer Behavior in Low-Income Rural Areas." The Review of Economics and Statistics, 83, no. 3:389-407.

Fuentes, Gabriel. 1996. "The Use of Village Agents in Rural Credit Delivery." Journal of Development Studies, 33, no. 2: 188-209.

Goetz, Anne Marie, and Rina Sen Gupta. 1996. "Who Takes the Credit? Gender, Power, and Control Over Loan Use in Rural Credit Programs in Bangladesh." World Development, 24, no. 1: 45-63.

Grameen Bank. 2004, 22/6. "Grameen Bank Historical Data Series" <http://grameeninfo.org/bank/hist2001.html>.

Haddad, Lawrence, Harold Alderman, and John Hoddinot. 1997a. Intrahousehold Resource Allocation in Developing Countries: Models, Methods, and Policy. Baltimore and London: The Johns Hopkins University Press.

-. 1997b. "Testing Competing Models of Intrahousehold Allocation." In Intrahousehold Resource Allocation in Developing Countries: Models, Methods, and Policy, edited by Lawrence Haddad, Harold Alderman, and John Hoddinot, 129-41. Baltimore and London: The Johns Hopkins University Press.

Hashemi, Sayed, Sidney Ruth Schuler, and Ann Riley. 1996. "Rural Credit Programs and Women's Empowerment in Bangladesh." World Development, 24, no. 4: 635-53.

Hayashi, F. 1995. "Is the Japanese Extended Family Altruistically Linked? A Test Based on Engle Curve." Journal of Political Economy, 103, no. 3: 661-74.

Hoff, Karla, and Joseph Stiglitz. 1998. "Moneylenders and Bankers: Price-Increasing Subsidies in a Monopolistically Competitive Market." Journal of Development Economics, 55: 485518.

Jain, Sanjay. 1999. "The Interaction of Formal and Informal Credit Markets in Developing Countries: Symiosis Versus Crowding Out." Journal of Development Economics, 59, no. 2: 419-44.

Jensen, Robert T. 2003. "Do Private Transfers 'displace' the Benefits of Public Transfers? Evidence from South Africa." Journal of Public Economics, 88: 89-112.

Khandker, Shahidur R. 1998. Fighting Poverty with Microcredit: Experience in Bangladesh. New York: Oxford University Press.

- 2003. Micro-Finance and Poverty: Evidence Using Panel Data from Bangladesh, The World Bank Development Research Group Working Paper no. 2945. Washington, D.C.

Khandker, Shahidur, and Mark Pitt. 2002. "The Impact of Group-Based Credit on Poor Households: An Analysis of Panel Data from Bangladesh."

Knowles, J.C., and R. Anker. 1981. "An Analysis of Income Transfers in a Developing Country." Journal of Development Economics, 8, no. 2: 205-26.

Kochar, Anjini. 1997. "An Empirical Investigation of Rationing Constraints in Rural Credit Markets in India." Journal of Development Economics, 53: 339-71. 
Lee, Y., W.L. Parish, and R.J. Willis. 1994. "Sons, Daughters, and Intergenerational Support in Taiwan." American Journal of Sociology, 99, no. 4: 1010-41.

Lucas, R.E.B., and O. Stark. 1985. "Motivations to Remit: Evidence from Botswana." Journal of Political Economy, 93, no. 5: 901-18.

Manski, Charles, and Steven Lerman. 1977. "The Estimation of Probabilities from Choice Based Samples." Econometrica, 45, no. 8: 1977-88.

McGarry, K., and R.F. Schoeni. 1995a. "Transfer Behavior in the Health and Retirement Study: Measurement and the Redistribution of Resources Within the Family." Journal of Human Resources, XXX, Supplement: S184-226.

- 1995b. Transfer Behavior Within the Family: Results from the Asset and Health Dynamics Survey, National Bureau of Economic Research Working Paper no. 5099. Cambridge, MA.

McGarry, Kathleen. 2000. Testing Parental Altruism: Implications of a Dynamic Model, National Bureau of Economic Research no. 7593. Cambridge, MA.

McKernan, Signe-Mary. 2002. "The Impact of Micro-Credit Programs on Self-Employment Profits: Do Non-Credit Program Aspects Matter?" Review of Economics and Statistics, 84, no. 1, February: 93-115.

Miller, Douglas, and Anna L. Paulson. 1999. Informal Insurance and Moral Hazard: Gambling and Remittances in Thailand, Kellogg Graduate School of Management, Northwestern University Working Paper.

Morduch, Jonathan. 1995. "Income Smoothing and Consumption Smoothing." Journal of Economic Perspectives, 9 (Summer): 103-14.

- 1998. Does Microfinance Really Help the Poor? New Evidence from Flagship Programs in Bangladesh, Harvard University and Stanford University Manuscript.

—. 1999. "The Microfinance Promise." Journal of Economic Literature, 37, no. 4, December: $1569-614$.

Paulson, Anna L. 2000. Insurance Motives for Migration: Evidence from Thailand, Kellogg Graduate School of Management, Northwestern University Working Paper.

Pitt, Mark. 1999b. "Reply to Jonathon Morduch's 'Does Microfinance Really Help the Poor? New Evidence from Flagship Programs in Bangladesh'," Brown University, October 14.

—. 2001. "The Effect of Nonagricultural Self-Employment Credit on Contractual Relations and Employment in Agriculture: The Case of Microcredit Programs in Bangladesh." Bangladesh Development Studies.

Pitt, Mark, and Shahidur Khandker. 1998. "The Impact of Group-Based Credit Programs on Poor Households in Bangladesh: Does the Gender of Participants Matter?" Journal of Political Economy, 106, no. 5: 958-96.

Pitt, Mark, Shahidur Khandker, and Jennifer Cartwright. 2003. Does Micro-Credit Empower Women? Evidence from Bangladesh, World Bank Policy Research Working Paper no. 2998.

Pitt, Mark, Shahidur Khandker, Omar Haider Choudhury, and Daniel Millimet. 2003. "Credit Programs for the Poor and the Health Status of Children in Rural Bangladesh." International Economic Review, 44, no. 1, February: 87-118.

Pitt, Mark, Shahidur Khandker, Signe-Mary McKernan, and M. Abdul Latif. 1999a. "Credit Programs for the Poor and Reproductive Behavior in Low-Income Countries: Are the Reported Causal Relationships the Result of Heterogeneity Bias?" Demography, 36, no. 1, February: 1-21.

Rashid, Mansoora, and Robert M. Townsend. 1994. Targeting Credit and Insurance: Efficiency, Mechanism Design, and Program Evaluation, World Bank Discussion Paper no. 47. 
Ravallion, Martin, and Lorraine Dearden. 1988. "Social Security in a 'Moral Economy': An Empirical Analysis for Java." Review of Economics and Statistics, 70, no. 1, February: 34-44.

Rosenzweig, Mark R., and Oded Stark. 1989. "Consumption Smoothing, Migration, and Marriage: Evidence from Rural India." Journal of Political Economy, 97 (August): 90526.

Rosenzweig, Mark R., and Kenneth Wolpin. 1994. "Parental and Public Transfers to Young Women and Their Children." The American Economic Review, 84, no. 5, December: 1195-212.

Schoeni, Robert F. 1997. "Private Interhousehold Transfers of Money and Time: New Empirical Evidence." Review of Income and Wealth, 43, no. 4, December: 423-48.

Secondi, Giorgio. 1997. "Private Monetary Transfers in Rural China: Are Families Altruistic?" The Journal of Development Studies, 33, no. 4, April: 487-511.

Shehabuddin, Rahnuma. 1992. Empowering Rural Women: The Impact of the Grameen Bank in Bangladesh. Bangladesh: Grameen Bank.

Sinha, Saurabh, and Imran Matin. 1998. "Informal Credit Transactions of Micro-Credit Borrowers in Rural Bangladesh." IDS Bulletin, 29, no. 4: 66-81.

Thomas, Duncan. 1997. "Incomes, Expenditures, and Health Outcomes: Evidence on Intrahousehold Resource Allocation." In Intrahousehold Resource Allocation in Developing Countries: Models, Methods, and Policy, edited by Lawrence Haddad, Harold Alderman, and John Hoddinot, 142-64. Baltimore and London: The Johns Hopkins University Press.

Townsend, Robert M. 1994. "Risk and Insurance in Village India." Econometrica, 62 (May): 539-91.

World Bank. 2001. World Development Report 2000/2001. New York, NY: Oxford University Press.

—. 2002. Poverty in Bangladesh: Building on Progress. Tech. Rept. no. 24299-BD.

—. 2003. Development Policy Review. Tech. Rept. no. 26154-BD. Washington, DC: World Bank.

Zeller, Manfred. 1994. "Determinants of Credit Rationing: A Study of Informal Lenders and Formal Credit Groups in Madagascar," International Food Policy Research Institute, Washington, DC, October. FCND Discussion Paper no. 2. 


\section{Appendix}

\section{Regression Results: Full Sets of Coefficients}

The coefficients from the three equation systems used to estimate the impact of program credit on interhousehold transfers received and sent are shown in Tables A1 and A2. The determinants of program credit given to women, program credit given to men, and interhousehold transfers conditional on program credit are shown in columns (1), (2), and (3) respectively. We estimate these three tobit equations jointly using limited information maximum likelihood in order to control for the correlation of the error terms between the credit and transfer equations. While the program credit coefficients are of primary interest and discussed in the text, we show the full set of coefficients here to give a better sense of the control variables.

The reduced form determinants of program credit (Tables A1 and A2, columns 1 and 2) show that variables measuring potential sources of interhousehold transfers are generally not significant determinants of the amount of program credit received by either men or women. Only the number of brothers of the household head who own land significantly affect the amount of credit men receive. The gender and age of the household head have opposite effects on expected credit for men and women. Having a male household head decreases the expected credit amount received by women and increases the expected credit amount received by men. While having an older household head increases expected credit for women but decreases it for men. Program credit increases with land holdings for men, but not for women. Education has no statistically significant effect on credit amounts for either men or women. Having no spouse present in the household decreases expected credit for women but has no statistically significant effect on men.

The reduced form determinants of interhousehold transfers received (Table A1, column 3) present some further evidence on differences between households that do and do not receive interhousehold transfers, but less than one might hope because the reduced form determinants are conditioned on program credit, our primary variable of interest. Thus the coefficient on the education of the household head, for example, tells us the effect of education on interhousehold transfers while holding constant program credit. We find that potential sources of interhousehold transfers, while not individually significant, are likely jointly significant. We also find that the older the household head and the more educated males are in the household, the more likely the household is to receive interhousehold transfers even after conditioning on program credit. The coefficients on the amount of program credit received are discussed in the text.

The reduced form determinants of interhousehold transfers sent (Table A2, column 3) indicate that, holding program credit constant, households send fewer transfers if brothers of the household head own land. This suggests that households with wealthy relatives may be less likely to send transfers (possibly because their relatives are wealthier and in turn need transfers less). Less expected, male-headed households are less likely to send transfers than female- 
headed households and older household heads are more likely to send transfers, after conditioning on program credit. Households with more educated women are more likely to send transfers, as are households without women present, holding credit constant. Households without a spouse present are less likely to send transfers than households with a spouse present, holding credit constant. Finally, non-target households (households owning more than half an acre of land and thus presumably wealthier) are more likely to send transfers than non-target households, holding credit constant. The coefficients on the amount of program credit received are discussed in the text. 
TABLE A1 - Estimates of the Impact of Log Program Credit on Log Relative Credit and Transfers Received 3 Equation System - Maximum Likelihood Estimates

\begin{tabular}{|c|c|c|c|c|c|c|}
\hline & \multicolumn{2}{|c|}{$\begin{array}{l}\text { Log Female Credit } \\
\text { Borrowed } \\
(1)\end{array}$} & \multicolumn{2}{|c|}{$\begin{array}{l}\text { Log Male Credit } \\
\text { Borrowed } \\
(2)\end{array}$} & \multicolumn{2}{|c|}{$\begin{array}{l}\text { Log Interhousehold } \\
\text { Transfers Received } \\
\text { (3) }\end{array}$} \\
\hline & Estimate & $\begin{array}{c}\text { Asymptotic } \\
\text { t-ratio }\end{array}$ & Estimate & $\begin{array}{c}\text { Asymptotic } \\
\text { t-ratio }\end{array}$ & Estimate & $\begin{array}{c}\text { Asymptotic } \\
\text { t-ratio }\end{array}$ \\
\hline Number of sisters of spouse who own land & -0.057 & $(-0.584)$ & 0.072 & $(0.634)$ & 0.047 & $(0.318)$ \\
\hline Number of brothers of spouse who own land & 0.032 & $(0.409)$ & 0.060 & $(0.591)$ & 0.081 & $(0.663)$ \\
\hline Number of parents of spouse who own land & -0.138 & $(-0.93)$ & 0.124 & $(0.660)$ & -0.084 & $(-.376)$ \\
\hline Number of sisters of head who own land & 0.041 & $(0.436)$ & -0.010 & $(-.092)$ & 0.250 & $(1.730)$ \\
\hline Number of brothers of head who own land & 0.048 & $(0.530)$ & 0.233 & $(2.051)$ & 0.264 & $(1.865)$ \\
\hline Number of parents of head who own land & 0.052 & $(0.287)$ & 0.246 & $(1.084)$ & 0.072 & $(0.250)$ \\
\hline Log of total household land assets (in decimals) & 0.046 & $(0.895)$ & 0.159 & $(2.310)$ & 0.031 & $(0.347)$ \\
\hline Highest grade completed by head & -0.033 & $(-.498)$ & -0.045 & $(-.501)$ & 0.040 & $(0.496)$ \\
\hline Male household head & -1.357 & $(-2.450)$ & 1.604 & $(1.994)$ & -2.384 & $(-3.796)$ \\
\hline Age of household head (in years) & 0.017 & (2.199) & -0.018 & $(-1.673)$ & 0.029 & (2.466) \\
\hline Maximum educational attainment of females & -0.065 & $(-1.363)$ & -0.056 & $(-.884)$ & 0.032 & $(0.464)$ \\
\hline Maximum educational attainment of males & 0.024 & $(0.387)$ & 0.133 & $(1.598)$ & 0.164 & $(2.079)$ \\
\hline No adult male in household & -0.564 & $(-.914)$ & & & -0.263 & $(-.311)$ \\
\hline No adult female in household & & & -0.968 & $(-1.044)$ & 1.884 & $(1.670)$ \\
\hline No spouse present in household & -0.913 & $(-2.577)$ & -0.644 & $(-1.275)$ & 0.885 & $(1.678)$ \\
\hline Log of amount borrowed by female from BRAC & & & & & -0.168 & $(-1.472)$ \\
\hline Log of amount borrowed by male from BRAC & & & & & 0.095 & $(0.760)$ \\
\hline Log of amount borrowed by female from BRDB & & & & & -0.189 & $(-1.588)$ \\
\hline Log of amount borrowed by male from BRDB & & & & & 0.022 & $(0.208)$ \\
\hline Log of amount borrowed by female from GB & & & & & -0.321 & $(-2.734)$ \\
\hline Log of amount borrowed by male from GB & & & & & 0.198 & $(1.342)$ \\
\hline Non-target household & & & & & -0.632 & $(-1.352)$ \\
\hline sigma (female credit) & & & & & 2.225 & $(33.822)$ \\
\hline sigma (male credit) & & & & & 2.437 & $(26.994)$ \\
\hline sigma (transfers) & & & & & 2.997 & $(21.087)$ \\
\hline$\rho$ (female credit/transfers) & & & & & 0.121 & $(0.780)$ \\
\hline$\rho$ (male credit/transfers) & & & & & -0.130 & $(-.978)$ \\
\hline
\end{tabular}

Source: Authors' weighted regressions from the 1991/92 World Bank/BIDS survey of rural Bangladesh.

General Notes: All three equations include village level fixed effect dummies. Individuals are considered adults at age 16. 
TABLE A2 - Estimates of the Impact of Log Program Credit on Log Relative Credit and Transfers Sent 3 Equation System - Maximum Likelihood Estimates

\begin{tabular}{|c|c|c|c|c|c|c|}
\hline & \multicolumn{2}{|c|}{$\begin{array}{l}\text { Log Female Credit } \\
\text { Borrowed } \\
(1)\end{array}$} & \multicolumn{2}{|c|}{$\begin{array}{l}\text { Log Male Credit } \\
\text { Borrowed } \\
(2)\end{array}$} & \multicolumn{2}{|c|}{$\begin{array}{l}\text { Log Interhousehold } \\
\text { Transfers Sent } \\
\text { (3) }\end{array}$} \\
\hline & Estimate & $\begin{array}{c}\text { Asymptotic } \\
\text { t-ratio }\end{array}$ & Estimate & $\begin{array}{c}\text { Asymptotic } \\
\text { t-ratio }\end{array}$ & Estimate & $\begin{array}{c}\text { Asymptotic } \\
\text { t-ratio }\end{array}$ \\
\hline Number of sisters of spouse who own land & -0.064 & $(-.659)$ & 0.076 & $(0.671)$ & 0.124 & $(0.930)$ \\
\hline Number of brothers of spouse who own land & 0.037 & $(0.472)$ & 0.041 & $(0.414)$ & 0.211 & $(1.498)$ \\
\hline Number of parents of spouse who own land & -0.158 & $(-1.072)$ & 0.171 & $(0.916)$ & -0.183 & $(-0.664)$ \\
\hline Number of sisters of head who own land & 0.045 & $(0.493)$ & 0.009 & $(0.091)$ & 0.172 & $(1.068)$ \\
\hline Number of brothers of head who own land & 0.039 & $(0.442)$ & 0.264 & $(2.361)$ & -0.743 & $(-4.264)$ \\
\hline Number of parents of head who own land & 0.049 & $(0.269)$ & 0.287 & $(1.253)$ & -0.255 & $(-0.632)$ \\
\hline Log of total household land assets (in decimals) & 0.046 & $(0.893)$ & 0.142 & $(2.063)$ & 0.021 & $(0.172)$ \\
\hline Highest grade completed by head & -0.026 & $(-0.385)$ & -0.063 & $(-0.710)$ & 0.164 & $(1.660)$ \\
\hline Male household head & -1.440 & $(-2.572)$ & 1.676 & $(2.056)$ & -2.536 & $(-2.575)$ \\
\hline Age of household head (in years) & 0.017 & $(2.188)$ & -0.020 & $(-1.834)$ & 0.029 & $(1.952)$ \\
\hline Maximum educational attainment of females & -0.060 & $(-1.307)$ & -0.058 & $(-0.943)$ & 0.176 & $(2.233)$ \\
\hline Maximum educational attainment of males & 0.020 & $(0.317)$ & 0.145 & $(1.767)$ & -0.057 & $(-0.634)$ \\
\hline No adult male in household & -0.629 & $(-0.980)$ & & & 0.450 & $(0.401)$ \\
\hline No adult female in household & & & -0.932 & $(-1.019)$ & 4.104 & $(3.129)$ \\
\hline No spouse present in household & -0.948 & $(-2.687)$ & -0.623 & $(-1.210)$ & -1.754 & $(-2.238)$ \\
\hline Log of amount borrowed by female from BRAC & & & & & 0.074 & $(0.788)$ \\
\hline Log of amount borrowed by male from BRAC & & & & & 0.247 & $(2.401)$ \\
\hline Log of amount borrowed by female from BRDB & & & & & -0.074 & $(-0.581)$ \\
\hline Log of amount borrowed by male from BRDB & & & & & 0.334 & $(3.117)$ \\
\hline Log of amount borrowed by female from GB & & & & & -0.060 & $(-0.528)$ \\
\hline Log of amount borrowed by male from GB & & & & & 0.305 & $(2.698)$ \\
\hline Non-target household & & & & & 2.502 & $(4.632)$ \\
\hline sigma (female credit) & & & & & 2.224 & $(33.721)$ \\
\hline sigma (male credit) & & & & & 2.432 & $(26.831)$ \\
\hline sigma (transfers) & & & & & 2.661 & $(13.248)$ \\
\hline$\rho$ (female credit/transfers) & & & & & 0.075 & $(0.550)$ \\
\hline$\rho$ (male credit/transfers) & & & & & -0.281 & $(-2.621)$ \\
\hline
\end{tabular}

Source: Authors' weighted regressions from the 1991/92 World Bank/BIDS survey of rural Bangladesh.

General Notes: All three equations include village level fixed effect dummies. Individuals are considered adults at age 16. 